\title{
International Law and Contract Interpretation
}

It is not uncommon to explain giving effect to a national law in the context of public international law by a failure of the latter to regulate certain matters that lie in the exclusive domain of the former. This explanatory pattern rests, as a rule, upon two basic elements: firstly, on the relevance of certain statuses, rights or interests to public international law and their appearance exclusively under national law and, secondly, on the unavailability of substituting rules in public international law that would make it possible to regulate the matter instead of national law. ${ }^{1}$

While a similar pronouncement on the relevance of national law for contract interpretation is not controversial, a recognition of a failure of international law to address contract interpretation is less straightforward than one might think at first glance. On the one hand, international law, in the sense of public international law, does indeed primarily regulate inter-state relations and thus seems to have nothing to offer for understanding national-law instruments - contracts. Unsurprisingly, contracts that appear in investment treaty arbitration, either ones of principal importance or of peripheral importance for investment disputes, do not benefit from the specifically crafted interpretative rules of public international law. On the other hand, public international law is not a closed system. Exposure to contracts and a lack of specific rules on contract interpretation in a public international law setting, makes it tempting to rely on structural and operational elements of public international law as a system, including its own interpretative rules, for understanding contracts for the specific purposes of public international law. This extension of interpretative rules of public international law to contract interpretation finds its rare application in the practice of international tribunals. In addition to the interpretative rules of public international law, substantive provisions of international law may potentially inform efforts for understanding contracts. For instance, international investment law as a specialised subfield of public international law may be viewed as offering certain answers for understanding a specific category of contracts - investment or state contracts. Scholars trace these interpretative answers in the emergence of doctrinal views in international

1 Case Concerning the Barcelona Traction, Light and Power Company, Ltd. (Belgium v. Spain) (Judgment of 5 February 1970) [1970] ICJ Rep 3; Ahmadou Sadio Diallo (Republic of Guinea v. Democratic Republic of the Congo), Judgement of 3 o November 2010, 675-676.

(C) YULIYA CHERNYKH, 2022 | DOI:10.1163/9789004414709_005

This is an open access chapter distributed under the terms of the CC BY-NC-ND 4Y0 lickensẹernykh - 9789004414709 Downloaded from Brill.come4/26/2023 12:10:18PM 
investment law in relation to stabilisation clause, waiver of immunity, limited liability clause, forum selection clause and some other provisions. ${ }^{2}$ Finally, the expansion of public international law sources (treaties and convention) beyond cross-border, inter-state cooperation in civil and commercial litigation and arbitration, directly to substantive regulation in the field of international commercial law, subjects contract interpretation, at least for these sources, to a direct regulation of international uniform rules. To summarise, all mentioned make a failure of public international law to govern contract interpretation if not less axiomatic, than at least necessitating a thorough and careful examination. Furthermore, a question as to whether public international law principles can apply to contracts and provide answers for their understanding seems not to be entirely outdated nowadays. ${ }^{3}$

This chapter, accordingly, verifies the capacity and limits of international law in its current shape to address contract interpretation. Instead of the relationship between public international law and national laws, the focus here turns to public international law per se. To this end, the work distances itself from a monist-dualist discussion and the constraints that each approach represents. ${ }^{4}$ The work also steps out of the box of international investment law as a subfield of public international law, which is a dominant theme in this book. In addition to international investment law, the potential extension in application of existing, mostly interpretative, rules of public international law

2 See also Chapter 4.

3 Richard B Lillich, "The Law Governing Disputes under Economic Development Agreements: Reexamining the Concept of "Internationalization"' in Richard B Lillich and Charles N Brower (eds), International Arbitration in the 21st Century: Towards "Judicialization" and Uniformity? (Transnational Publishers, Inc. 1994) 61-114.

4 For a comprehensive overview of the peculiarities of dualist and monist approaches in relation to state contracts, see Ivar Alvik, Contracting with Sovereignty: State Contracts and International Arbitration (Hart Publishing 2011) 58-85; A F M Maniruzzaman, 'State Contracts in Contemporary International Law: Monist versus Dualist Controversies' (2001) 12 European Journal of International Law 309; Ian Brownlie, Principles of Public International Law (7th edn, Oxford University Press 2008) 31-34. Three propositions that seem uncontested by any of these approaches, either monist, dualist or a mixture of both, seem to be plausible. Firstly, national law is primarily applicable to contracts, and by extension, to contract interpretation. Secondly, international law can be applied in principle to contractual rights under certain premises and circumstances (and indeed what the premises and circumstances precisely are - monism and dualism differ). Thirdly, if international law is applied to contracts/contractual rights, its application is not of the same quality and effect as primary rules - contract law (again both monism and dualism differ on the precise effect of international law vis-à-vis national law). This common ground permits one to isolate the question from various doctrinal and theoretical controversies of relations between international and national law and to focus on international law, and its rules, per se. 
to contract interpretation as well as the emergence of specific international regulations in new terrains of international law, are brought into focus.

The chapter starts by defining the (dissolving) borders of international law relevant for a focus on contract interpretation. It then turns to verifying the capacity of all classical sources of public international law to provide rules applicable to contract interpretation and to substitute national law regarding contract interpretation. Screening public international law in this way, the chapter looks both at a parallel set of interpretative technical rules, grasping various canons and principles of interpretation, and substantive regulation that may provide a relevant background for an interpretative exercise. Importantly, the work considers also other contracts that are not necessarily investment contracts, though the latter category is undoubtedly central to this inquiry because of being more exposed to the direct application of international law and the extension of international law for their ascertainment.

\subsection{The Concept of International Law}

Of the numerous perspectives pertaining to concepts of international law, ${ }^{5}$ one in particular frames the inquiry detailed in this chapter. International law

$5 \quad$ This list is not structured to necessarily present opposing views, but rather the plurality of facets in understanding what international law is and what it is not. For a discussion on the concept of international law, see, for instance, Philip Allot, 'The Concept of International Law' (1999) 10 European Journal of International Law 31, 31-50; James Crawford, 'Chance, Order, Change: The Course of International Law, General Course on Public International Law' (2013) 365 Recueil des Cours de l'Académie de Droit International, 15 and subsequent; Martti Koskenniemi, 'The Fate of Public International Law: Between Technique and Politics' (2007) 70(1) Modern Law Review 1, 1-30; Jean D'Aspremont, Epistemic Forces in International Law: Essays on the Foundational Doctrines and Techniques of International Legal Argumentation (Edward Elgar Publishing 2015) (the work of Jean D'Aspremont is also helpful in giving direction regarding the discourse on various understandings of international law as a set of rules and institutions, a set of authoritative processes, a combination of rules and processes, a set of legal relations, a discourse, a tool to create authoritative claims, a political project, etc.) For a discussion on whether international law is law, see Joshua Kleinfeld, 'Skeptical Internationalism: A Study of Whether International Law is Law' (2010) 78(5) Fordham Law Review 2451 and Andrew T. Guzman, 'Rethinking International Law as Law' (2009) 103 American Society of International Law Proceedings 155, 155-157. For a discussion on whether international law is a system, see Eyal Benvenisti, 'The Conception of International Law as a Legal System' (2007) 50 German Yearbook of International Law 393, 393-405; Yoram Dinstein, 'International Law as a Primitive Legal System' (1986) 19(1) New York University Journal of International Law and Politics 1. For a discussion on whether international law is international, see Anthea Roberts, Is International Law International? (Oxford University Press 2017); Anthea Roberts, 'Is International Law 
appears in a normative, or even in a rather instrumental sense as a set of binding rules and principles that come into existence because of consent between states and that co-exist with national laws. Procedures and other facets of international law are of less concern for this chapter, as are numerous approaches to international law, including sociological, philosophical and other. ${ }^{6}$ What matters here is the potential availability of rules on an international level that can inform or operate for contract interpretation - directly or by extension and possibly substitute an originally applicable regime of national law.

Limiting this inquiry to the rules of international law and focusing primarily on interpretative rules, this chapter also looks at substantive regulation that results from the dissolving and expanding the regulatory scope of international law. Furthermore, if inter-state consent remains a central drive behind the appearance of these rules, inter-state relations no longer serve as the exclusive regulatory field. Two diverse developments expand the borders of international law beyond exclusive inter-state relations and beyond the exclusive public nature of these relations. One development features the increased engagement of international law with non-state actors ${ }^{7}$ and resulting

International? Continuing the Conversation' (Blog of the European Journal of International Law, 9 February 2018) <www.ejiltalk.org/is-international-law-international-continuingthe-conversation/> accessed 25 June 2021. Above all a view of Frédéric Mégret seems to embrace international law in its entirety best: 'International law's peculiar approach to law can perhaps best be described as that of a law that is 'in between', characterised simultaneously by what it seeks to escape from (e.g. wars of religion), what it is not (e.g. domestic law), and what it aspires to achieve (perpetuation, surpassing, transformation, etc.). This quality is a precarious one that relies on a particular conjunction of historical forces, preferred subjects, a certain ethos, a concept of society, legal constructs and a functional architecture' - see Frédéric Mégret, 'International Law as Law' in James Crawford and Martti Koskenniemi (eds), The Cambridge Companion to International Law (Cambridge University Press 2012) 88 .

6 For instance, Moshe Hirsch, Invitation to the Sociology of International Law (Oxford University Press 2015); Thomas Skouteris, 'Fin de NAIL: New Approaches to International Law and its Impact on Contemporary International Legal Scholarship' (1997) 10 (3) Leiden Journal of International Law 415; Samantha Besson, 'Moral Philosophy and International Law' in Anne Orford and Florian Hoffmann (eds), The Oxford Handbook of the Theory of International Law (Oxford University Press 2016) 386-406.

7 A recognition of the implications that non-state actors (individuals, investors, multinational corporations, etc.) contribute to the development of international law is by no means new. Here are a few examples - Ben Golder, 'Theorizing Human Rights' in Anne Orford and Florian Hoffmann (eds), The Oxford Handbook of the Theory of International Law (Oxford University Press 2016) 685-700; Fleur Johns, 'Theorizing the Corporation in International Law' in Anne Orford and Florian Hoffmann (eds), The Oxford Handbook of the Theory of International Law (Oxford University Press 2016) 636-654; Math Noortmann, August Reinisch and Cedric Ryngaert (eds), Non-State Actors in International Law (Hart 
functional specialisation in international law, or its fragmentation. ${ }^{8}$ Another development relates to the ongoing emergence of public international law instruments attempting to harmonise a broad spectrum of private, decentralised relations, including areas such as the international sale of goods, financial leasing, agency, factoring, banking and other fields. ${ }^{9}$

The former horizontal development of international law resulting among others in the emergence of international investment law, while being contested at the early stage of its inception, has now received firm canonisation as a part of international law..$^{10}$ The latter vertical development - also captured by labels of globalisation of private law, globalisation of private international law, the privatisation of international law or appearance of international uniform law - still causes inconveniences to its perception as a part of international law proper. Taken together, despite substantial differences in methods and focuses, both developments represent a consolidated view on international law that is marked by increased engagement with contracts and other diverse relations of a private nature. This broader perspective enables one not to miss any sign of existing international legal rules, either substantive or interpretative, or a principle that might be relevant for contract interpretation.

Publishing 2015); Astrid Kjeldgaard-Pedersen, The International Legal Personality of the Individual (Oxford University Press 2018).

8 Study Group of the International Law Commission, 'Fragmentation of International Law: Difficulties Arising from the Diversification and Expansion of International Law' (finalized by Martti Koskenniemi, 13 April 20o6) <http://legal.un.org/ilc/documentation/ english/a_cn4_l682.pdf> accessed 25 June 2021. In his recent interview, Martti Koskeniemi valuably captures fragmentation in international law arising from diversification and expansion of international law through the metaphor of 'managerial projects' - see Van Den Meerssche, 'Interview: Martti Koskenniemi on International Law and the Rise of the Far-Right' (Opinio Juris, 10 December 2018) <http://opiniojuris.org/2018/12/10/interview -martti-koskenniemi-on-international-law-and-the-rise-of-the-far-right/>accessed 25June 2021.

9 One can build a list from early instruments of harmonisation, from the Hague Rules on Bills of Lading (1924), the Warsaw Convention on Air Carriage, and the Geneva Convention on Bill of Exchange and Promissory Notes (1930) to more contemporaneous sources, such as the UN Convention on Independent Guarantees and Stand-by Letters of Credit (1995), the CISG, the UN Convention on Limitation Period in the International Sale of Goods (1974, amended 1980), the UNIDroit Convention on Agency in the International Sale of Goods (1983 - not in force), the UNIDroit Convention on International Financial Leasing (1988), the UNIDRoIT Convention on International Factoring (1988).

10 See, for instance, the reference by the International Law Commission to international investment law as a self-contained regime within public international law. See also Freya Baetens (ed), Investment Law within International Law Integrationist Perspectives (Cambridge University Press 2013). 
On the face of these two trends, another binary public-private divide that frequently operates as a criterion in separating international law (public dimension) from national law(s) (private dimension) ceases to define what international law is for this chapter. ${ }^{11}$ The precise borders of the extension of international law have yet to be analysed, but the fact that international law is no longer exclusively about inter-state relations of a public nature seems to find increasingly firm support. It is also yet to be seen whether contracts turn into the object of international law so to trigger the emergence of the specific rules on contract interpretation or extension of the existent rules. What is clear is that the regulatory scope of international law has become broader and more complicated if compared with how international law, with its state-centralism, was perceived in the days of Arnold McNair, Hersch Lauterpacht and Wilfred Jenks. Neoliberal politics ${ }^{12}$ appeared as an important driver of more recent changes for international law, prompting an extension of its borders and impacting its dominant rationales. In other words, international law is not reduced to being viewed via the traditional conceptual lenses of inter-state rules exclusively regulating inter-state relations of a public character, or public international law. The broad picture of international law under examination in this chapter, in addition to its undeniable subfield of international investment law, also includes what is referred to as private international law (its international dimension) and international commercial law.

The precise model of international law as addressed in this inquiry may be presented as an amalgamation of the two views. The first is the public-centred view of James Crawford which emphasises the traditional perspective of international law, assigning the state a central role, but recognising the openness of public international law as a system, as well as its historical determinacy.13 The second is the private-centred view of Alex Mills acknowledging the public

11 Abandoning the public-private divide in defining the regulatory scope of international law I am attempting to broaden the scope of this investigation. At the same time, I am not dismissing the tension between private and public domains in contract interpretation.

12 For a valuable overview of neoliberal politics and international law see Honor Brabazon (ed), Neoliberal Legality Understanding the Role of Law in the Neoliberal Project (Routledge 2017).

13 See, James Crawford, 'Chance, Order, Change: The Course of International Law, General Course on Public International Law' (2013) 365 Recueil des Cours de l'Académie de Droit International 1, 27-252. More recently, addressing political challenges, such as Brexit, South Africa's purported withdrawal from the Rome Statute, and the United States' announced withdrawal from the Paris Agreement in 2018, Crawford wrote about international law as a stable sedimentary formation at a risk of erosion of its boundaries - James Crawford, 'The Current Political Discourse Concerning International Law' (2018) 81 (1) Modern Law Review 1, 2, 21. 
foundations of private international law and the private foundations of public international law. Overall, Mills appears to subscribe to the view that private international law is more than just the harmonisation of national law through public international law sources. At least part of the function of its rules is 'fundamentally 'public', 'international', and 'systemic' in its substantive character - it has at least a relationship of functional equivalence to some of the global governance ambitions of public international law.'14 If public international law undoubtedly underpins the formation of international law, this border erosion, or the affiliation of private international law with international law, has long been debated. The primary source of doubt comes from the obvious - the origin and function of private international law that demonstrates a tight and frequently indivisible connection with national regulation. This chapter recognises the mutual penetration of public international law and private international law and acknowledges private aspects in public international law and public international law aspects in private international law..$^{15}$

Free from any self-imposed, predetermined restriction on the regulatory scope of international law, this chapter's perspective is essential for an objective attempt to address the capacity of international law to interpret nationallaw instruments - contracts. International law appears here as having no predetermined agenda for its own development. It is not bound to exclusively regulate inter-state conduct. Nor is it banned from inward looking and substituting national regulation in certain fields. If one sees Crawford's model of international law as a formation consisting of the stable fundamentals of public international law but open to new horizons with the Mills' understanding of the mutual penetration between private international law and public international law, albeit limited or moderate, one would get a picture of international law that is relied upon here. This broad perspective opens the door for the investigation of international law in its current shape. At the same time, it does not assert that international law necessarily has proper answers for contract interpretation. In other words, released from pre-existing flat denials or affirmations, this chapter tries to establish whether international law offers

14 Alex Mills, 'Connecting Public and Private International Law' in Verónica Ruiz AbouNigm and others (eds), Linkages and Boundaries in Private and Public International Law (Hart Publishing 2018) 12-13.

15 See also Alex Mills, The Confluence of Public and Private International Law: Justice, Pluralism and Subsidiarity in the International Constitutional Ordering of Private Law (Cambridge University Press 20o9); Lucy Reed, 'Mixed Private and Public International Law Solutions to International Crises' (306) Recueil des Cours de l'Académie de Droit International 181, 199-210. 
anything in relation to contract interpretation, and if so, how the concepts and apparatus of international law can assist, if at all, for understanding contractual instruments.

Accepting the broad content of the regulatory scope of international law in a binary distinction between international law and national law as two distinct legal orders this chapter also recognises the unavoidable, namely that a line between international law and national law is relative on many occasions. International law develops in many respects from conceptual frames of national laws. Its interpretative apparatus has not entirely lost its nexus with the legal method developed in national legal systems. Its penetration into or operation within the national legal order is frequently premised on national laws. The independence of international law is particularly elusive in the case of international uniform law when harmonised international law is premised on national implementations. Nevertheless, it is also recognised that international law retains its distinctiveness, having interstate consent as a primary condition for its emergence. This chapter accordingly focuses on international law as a separate legal order in order to examine its possible impact on the interpretation of contracts that appear in the setting of public international law in investment treaty arbitration.

Regarding the timing of the inquiry, given the departure from the restrictions of the classical view on international law, it goes without saying that it is the contemporary shape of international law that matters for this chapter. Historical observations on the status of international law whenever raised serve to explain the origin and the current shape of the rules of international law in focus and to exhibit the existing tension in their possible extension to ascertaining the content of contractual provisions. These observations are not meant to form a complete historiography of what preceded the emergence of international investment law, or international commercial law, or the confluence of private international law and public international law, something that has already been extensively and capably addressed by other scholars. ${ }^{16}$

16 The attractiveness of the linear, evolutive development in international law that enables one to present a comprehensive narrative of shortcomings in diplomatic protection, increased protection through mixed claims commissions and the emergence of investment treaty protection became dominant for the public international law wing of scholars who address contract protection in international investment law. For international commercial law, no linear development can be presented. Harmonisations and the appearance of uniform rules relating to international commercial contracts in public international law sources are undoubtedly growing, but their success is diverse and their capacity to exclude the relevance of national laws is still limited. It is accordingly no surprise that instead of being exhaustive, historical observations here are rather selective and illustrative. These observations are captured primarily through early arbitral 
Prioritising the current state of international law, or lex lata, this chapter permits a limited investigation of ongoing initiatives and further distilling of the borders of international law that can be potentially marked as lex ferenda. ${ }^{17}$

The approach of this chapter, which attempts to be framed as 'an unbiased view' on international law, or more precisely on its regulated subject, is not opportunistic or deprived of principle. While broadening the scope of the regulation of international law beyond inter-state conduct, or public international law, to what can be largely seen as international commercial law and private international law, the investigation is kept within the classical structural frame of international law consisting of sources of public international law as defined by Article 38 of the ICJ Statute. ${ }^{18}$

The focus here primarily turns to two sources - international treaties and general principles of law recognised by civilised nations. International treaties warrant attention because they are more reactive to new challenges and shape modern international law. Furthermore, they are easily ascertainable. ${ }^{19}$ Central to exploring the role of treaties for contract interpretation would be the VCLT that, albeit itself relating to the interpretation of treaties, may be largely viewed as shaping the overall interpretative paradigm of international law. General principles of law also serve as an important source for investigation of the capacity of international law to address the ascertainment of the content of contractual provisions. ${ }^{20}$ Compared with treaties, general principles of

awards and scholarly writings that feature private and public wings in the development of international law and their confluence. For scholarly works, see, for instance, Ivar Alvik, Contracting with Sovereignty: State Contracts and International Arbitration (Hart Publishing 2011) 12-45; Jean Ho, State Responsibility for Breaches of Investment Contracts (Cambridge University Press 2018) 1-6o.

17 On lex ferenda and distinctions with lex lata see/listen Ki-Gab Park 'Lex Ferenda in International Law' (lecture, UN Audiovisual Library) <http://legal.un.org/avl/ls/ParkKiGab_IL.html> last accessed 25 June 2021.

18 Even though Article 38 does not pretend to enumerate 'sources' in a strict sense, it is widely perceived as a complete list of sources of international law (with varying role) - Jan Brownlie, Principles of Public International Law (7th edn, Oxford University Press 2008) 5 .

19 No complexity arises as a rule with the establishment of the content of a treaty in comparison with the difficulties associated with making the evidence of customary international law - see Summaries of the Work of the International Law Commission 'Ways and Means for Making the Evidence of Customary International Law More Readily Available' available at <http://legal.un.org/ilc/summaries/__4.shtml> accessed 25 June 2021.

20 General principles of law as sources of international law have recently received increasing attention. At its 7oth session, in 2018, the International Law Commission decided to include the topic relating to general principles of law in its programme of work, on the basis of the recommendation of the Working Group on the long-term programme of work. The Commission decided to appoint Mr. Marcelo Vázquez-Bermúdez as Special Rapporteur for the topic. The first report of the Special Rapporteur and the interim report 
law are less proactive but more penetrating. Their relevance for investigation is premised precisely on their primary function to respond to uncertainties in the regulatory framework of international law. If treaties do not address contract interpretation, it is general principles which have to be tested first. Taken historically, the principles stem from the fundamental values of national legal systems and inherit their rationale. Their operation is frequently perceived as being interpretative in nature and even if it can be argued that no specific rules have appeared in international law that can help to understand contracts, it has to be verified whether general principles may suffice to supplement the lacunae, especially when lacunae relate to interpretation. ${ }^{21}$

The remaining source - international customs - is also considered along with sources for the clarification of the content of international law as judicial decisions and the teachings of the most highly qualified publicists in the world. In the contexts of contracts, scholars usually address these sources from the perspective of state responsibility for breach of investment contracts.

And if the role of customary international law is arguably lacking ${ }^{22}$ in this regard, the role of arbitral awards is remarkably augmenting. ${ }^{23}$ The chapter will verify whether the capacity of these sources results in rules for the interpretation of investment contractsand possibly othertypes of contracts appearing in investment treaty arbitration. In what relates to scholarly publications, the chapter will attempt to identify those scholarly publications which, while dealing with

by the Chair of the Drafting Committee on draft conclusion 1 provisionally adopted by the Committee are available here <http://legal.un.org/ilc/sessions/71/ $>$ accessed 25 June 2021. See also, Jean D’Aspremont, 'What Was not Meant to Be: General Principles of Law as a Source of International Law' in Riccardo Pisillo Mazzeschi and Pasquale De Sena (eds), Global Justice, Human Rights and the Modernization of International Law (Springer 2018) and Charles T Kotuby Jr and Luke A Sobota, General Principles of Law and International Due Process: Principles and Norms Applicable in Transnational Disputes (Oxford University Press 2017).

21 The role of general principles of law together with customary international law are directly recognised for assisting in the interpretation of treaties that relate to the fragmented field of international law - see the Report of the Study Group of the International Law Commission finalized by Martti Koskenniemi, 'Fragmentation of International Law: Difficulties Arising from the Diversification and Expansion of International Law' (13 April 20o6) <http://legal.un.org/ilc/documentation/english/a_cn4_l682.pdf> accessed 25June 2021.

22 Jean Ho, 'The Evolution of Contractual Protection in International Law: Accessing Diplomatic Archives, Discovering Diplomatic Practice, and Constructing Diplomatic History' in Stephan W Schill and others (eds), International Investment Law and History (Edward Elgar Publishing 2018) 240.

23 Jean Ho, State Responsibility for Breaches of Investment Contracts (Cambridge University Press 2018) 61-88. 
contract interpretation in investment treaty arbitration, may be viewed as coming closer to identifying the relevant rules of international law.

As a final comment on the scope of inquiry, being about international law, broadly understood, this chapter is not about lex mercatoria, ${ }^{24}$ as non-state sets of rules or principles elaborated in the practice of international arbitration, nor is it about other transnational soft law regulation related to contract interpretation. While a certain overlap in ideas and principles between international law proper, lex mercatoria and transnational soft law regulation is unavoidable, mostly because of the common origin in general principles of law and before that in national law, ${ }^{25}$ this study is about international law shaped by the classical sources of public international law as defined by Article 38 of the ICJ Statute, and importantly enough applied as such.

\subsection{Treaties}

\subsubsection{Rules on Treaty Interpretation}

Despite a well-understood first impulse to reject even posing a question on a possible extension of the rules of treaty interpretation to contract interpretation in investment treaty arbitration, there are reasons to ask it. No doubt, treaties and contracts remain different. However, the rules regarding their interpretation, it could be argued, are not necessarily that different. Both rules on treaty and contract interpretation share a common feature: they attempt to accurately distil the meaning behind the parties' consent. In the case of treaties, it is the common intent of states who are the contracting parties to a treaty; in the case of contracts, it is the common intent of the contracting parties. When states or their organs are directly a party to a contract - and investment treaty arbitration evidences a considerable number of such contracts concluded with a broad range of state-related entities ${ }^{26}$ - even parties largely

24 For the non-state origin of lex mercatoria and its nature as 'an analytical framework for understanding the private law instruments that structure normative expectations in international commercial and financial transactions outside of the traditional sources of domestic and international law', see Stephan W Schill, 'Lex Mercatoria', Max Planck Encyclopedia of Public International Law <https://opil.ouplaw.com/view/10.1093/law:epil/9780199231 69o/law-978019923169o-e1534> updated June 2014, accessed 25 June 2021.

25 For the origin of the general principles of law, including principles that are international, see, for instance, Charles T Kotuby Jr. and Luke A Sobota, General Principles of Law and International Due Process: Principles and Norms Applicable in Transnational Disputes (Oxford University Press 2017) 3-54.

26 For instance, the cases as follows relate to contracts concluded with a state or state-related entity Azurix Corp.v. The Argentine Republic, ICSID Case No. ARB / o1/12, Award dated 14July 
2006, para. 41; Bayindir Insaat Turizm Ticaret Ve Sanayi A.S. v. Islamic Republic of Pakistan, ICSID Case No. ARB/o3/29, Award dated 27 August 20o9, para. 9, 11-13; Ceskoslovenska Obchodni Banka, A.S. v. The Slovak Republic, ICSID Case No. ARB/97/4, Award dated 29 December 2004, para. 1; Chevron Corporation (USA) and Texaco Petroleum Company (USA) v. The Republic of Ecuador, UnCitral, PCA Case No. 34877, Final Award, 31 August 2011, p. 4; Compañiá de Aguas del Aconquija S.A. and Vivendi Universal S.A. v. Argentine Republic, ICsid Case No. ARB/97/3 (formerly Compañia de Aguas del Aconquija, S.A. and Compagnie Générale des Eaux v. Argentine Republic), Award dated 20 August 2007, para. 1.1.1; EDF International S.A., SAUR International S.A. and León Participaciones Argentinas S.A. v. Argentine Republic, ICsID Case No. ARB/o3/23, Award, 11 June 2012, para. 50; Eureko B.V.v. Republic of Poland, UnCiTral, Partial Award dated 19 August 2005, para. 41; Gustav $F W$ Hamester GmbH \& Co KG v. Republic of Ghana, ICsID Case No. ARB/o7/24, Award dated 18 June 2010, para. 22; IBM World Trade Corporation v. República del Ecuador, ICSID Case No. ARB / O2/10, Decision on Jurisdiction and Competence dated 22 December 2003, para. 3, 50; Impregilo S.p.A. v. Argentine Republic, ICSID Case No. ARB/07/17, Award dated 21 June 2011, para. 14; Lanco International Inc. v. The Argentine Republic, ICSID Case No. ARB / 97/6, Preliminary Decision: Jurisdiction of the Arbitral Tribunal dated 8 December 1998, para. 5; Millicom International Operations B.V. and Sentel GSM SA v. The Republic of Senegal, ICSID Case No. ARB/o8/20, Decision on the Application for provisional measures submitted by the Claimants dated 9 December 2009, para. 12; David Minnotte \& Robert Lewis v. Republic of Poland, ICSID Case No. ARB (AF)/10/1, Award dated 16 May 2014, para. 71; MTD Equity Sdn. Bhd. and MTD Chile S.A. v. Republic of Chile, ICSID Case No. ARB $/ 01 / 7$, Award dated 25 May 2004, para. 54; Perenco Ecuador Ltd. v. The Republic of Ecuador and Empresa Estatal Petróleos del Ecuador (Petroecuador), ICSID Case No. ARB / 08/6, Decision on Jurisdiction dated 30 June 2011, para. 12; Plama Consortium Limited v. Republic of Bulgaria, ICSID Case No. ARB/03/24, Award dated 27 August 2008, para. 56-57, 63; SGS Société Générale de Surveillance S.A. v. Islamic Republic of Pakistan, ICSID Case No. ARB / o1/13, Decision of the Tribunal on Objections to Jurisdiction dated 6 August 2003, para. 1; SGS Société Générale de Surveillance S.A. v. The Republic of Paraguay, ICSID Case No. ARB/o7/29, Award dated 10 February 2012, para. 26; SGS Société Générale de Surveillance S.A. v. Republic of the Philippines, ICSID Case No. ARB/ o2/6, Decision of the Tribunal on Objections to Jurisdiction dated 29 January 2004, para. 13; Suez, Sociedad General de Aguas de Barcelona, S.A. and Vivendi Universal, S.A. v. Argentine Republic (II), ICSID Case No. ARB/o3/19 (formerly Aguas Argentinas, S.A., Suez, Sociedad General de Aguas de Barcelona, S.A. and Vivendi Universal, S.A. v. Argentine Republic), Award dated 9 April 2015, para. 2; Tethyan Copper Company Pty Limited $v$. Islamic Republic of Pakistan, ICSID Case No. ARB/12/1, Award dated 12 July 2019, para. 132; Decision on Jurisdiction and Liability dated 10 November 2017, para. 32; UAB E energija (Lithuania) v. Republic of Latvia, ICSID Case No. ARB/12/33, Award dated 22 December 2017, para. 100; Caratube International Oil Company LLP and Devincci Salah Hourani v. Republic of Kazakhstan, ICSID Case No. ARB /13/13, Award, 27 September 2017, para. 14; Vigotop Limited v. Hungary, ICSID Case No. ARB/11/22, Award datedı October 2014, para. 141; Mamidoil Jetoil Greek Petroleum Products Societe S.A. v. Republic of Albania, ICSID Case No. ARB/11/24, Award dated 30 March 2015, para. 81; Werner Schneider, acting in his capacity as insolvency administrator of Walter Bau Ag (In Liquidation) v. The Kingdom of Thailand, UNCITRAL (formerly Walter Bau AG (in liquidation) v. The Kingdom of Thailand), Award dated 1 July 2009, para. 2.35; Burlington Resources Inc. v. Republic of Ecuador, ICSID Case No. ARB / o8/5 (formerly Burlington Resources Inc. and others v. Republic of Ecuador and Empresa 
viewed may partly overlap. The shared focus on the parties' consent in contract and treaty interpretation makes both contract interpretation and treaty interpretation somewhat distinct from statutory interpretation, which is more concentrated on objectivised text as a reflection of the legislature's intent.

The desire to rely on the rules of treaty interpretation may be further strengthened by their historical origin, which demonstrates a direct connection with contract interpretation rules. Writing his inaugural work before the emergence of the VCLT, Hersch Lauterpacht acknowledged that principles of contract interpretation can be relied upon for treaty interpretation insofar as they are general and not specifically tied to a concrete jurisdiction. ${ }^{27}$ As an international public

Estatal Petróleos del Ecuador (PetroEcuador)), Decision on Liability dated 14 December 2012, para. 6; National Grid plc v. The Argentine Republic, Uncitral, Award dated 3 November 2008, para. 57; TSA Spectrum de Argentina S.A. v. Argentine Republic, ICSID Case No. ARB/05/5, Award dated 19 December 2008, para. 2, 8; Mr. Kristian Almås and Mr. Geir Almås v. The Republic of Poland, PCA Case No 2015-13, Award dated 27 June 2016, para. 4; Swisslion DOO Skopje v. The former Yugoslav Republic of Macedonia, ICSID Case No. ARB/og/16, Award dated 6 July 2012, para. 56; MNSS B.V. and Recupero Credito Acciaio N.V. v. Montenegro, ICSID Case No. RB(AF)/12/8, Award dated 4 May 2016, para. 46. The cases as follows evidence contracts concluded with state enterprises Garanti Koza LLP v. Turkmenistan, ICSID Case No. АRв/11/20, Award dated 19 December 2016, para. 4; William Nagel v. The Czech Republic, scC Case No. 049/2002, Final Award dated 9 September 2003, para. 1, 51; Occidental Petroleum Corporation and Occidental Exploration and Production Companyv. The Republic of Ecuador (II), ICSID Case No. ARB/ 06/11, Award dated 5 October 2012, para. 115, p. viii; Deutsche Bank AG v. Democratic Socialist Republic of Sri Lanka, ICSID Case No. ARB/o9/2, Award dated 31 October 2012, para. 6; Flemingo DutyFree Shop Private Limited v the Republic of Poland, UnCITral, Award dated 12 August 2016, para. 6; Unión Fenosa Gas, S.A. v. Arab Republic of Egypt, ICSID Case No. ARB/14/4, Award dated 31 August 2018, para. 3.8, 5.16-5.17; Nykomb Synergetics Technology Holding $A B v$. The Republic of Latvia, scc, Arbitral Award dated 16 December 2003, para. 1.1.

27 Published in 1927 and still widely cited, Lauterpacht's monograph 'Private Law Sources and Analogies of International Law' explains the appearance of analogous reasoning based on private law sources in public international law precisely by the underdeveloped status of the latter: 'In modern international law the application of private law is, as a rule, rejected by positivist publicists as threatening the independence and the scientific character of international law, and as introducing by a side wind the discarded law of nature. An uncritical iconoclasm in relation to private law is indeed one of the characteristic features of modern international law, in spite of the fact that the rejected analogy reappears in the writing of modern positivists under the form of conceptions of general jurisprudence, of the reason of the thing, and of logical deductions.', see Hersch Lauterpacht, Private Law Sources and Analogies of International Law: With Special Reference to International Arbitration (Longmans, Green and Co. Ltd. 1927; reprinted 2013 by The Lawbook Exchange) 297. Lauterpacht clarified that analogies mattered not only for the formative part of international law, but also contemporaneously, in 1927, when they penetrated the reasoning, despite the opposition of positivists either directly or under other premises. Criticising ' $[\mathrm{t}]$ he habit of falling back 
law scholar, Lauterpacht has not developed an argument regarding how different regulation, in respect to contract interpretation under various national laws can be, nor has he given examples of those general principles of contract interpretation that were not tied to a particular jurisdiction. He was cautious enough to emphasise that the principles of contract interpretation thus relied upon for treaty interpretation should be 'general'. Later, Lauterpacht became one of the Special Rapporteurs and an active participant in the work of the International Law Commission on the elaboration of the VCLT. ${ }^{28}$

Because the VCLT was primarily a matter of codification of customary international law on treaties, including those on treaty interpretation, the practice of international courts and tribunals became an object of rigorous investigation. Reliance of these courts and tribunals on principles of contract interpretation could not remain unnoticed. Common principles or canons of interpretation, equally relevant for the interpretation of contracts, treaties and statutes, appeared in focus as well. A report by another Special Rapporteur, Sir Humphrey Waldock, on issues of treaty interpretation, not only acknowledged their existence, but expressly enumerated them:

The great majority of cases submitted to international adjudication involves the interpretation of treaties, and the jurisprudence of international tribunals is rich in references to principles and maxims of interpretation. In fact, statements can be found in the decisions of international tribunals to support the use of almost every principle or maxim of which use is made in national systems of law in the interpretation of statutes and contracts; for example, those frequently referred to in their Latin forms, ut res magis valeat quam pereat, contra proferentem, eiusdem generis, expressio unius est exclusio alterius, generalia specialibus non derogant. ${ }^{29}$

on private $l a w^{\prime}(V I I)$, Lauterpacht advocated a more balanced approach towards private law analogies in international law. Such an approach required, prior to turning to analogy based on private law sources, an attempt to solve an issue through international law 'by filling the gap by means of logical deductions from existing rules of international law or of analogy to them.' - see Hersch Lauterpacht, Private Law Sources and Analogies of International Law: With Special Reference to International Arbitration (Longmans, Green and Co. Ltd. 1927; reprinted 2013 by The Lawbook Exchange) 85 .

28 The work spanned from 1949 to 1969.

29 Sir Humphrey Waldock, "Third Report on the Law of Treaties, by Sir Humphrey Waldock, Special Rapporteur' (A/CN.4/167, 1964) 2 Yearbook of the International Law Commission para. 5, p.54. <http://legal.un.org/ilc/documentation/english/a_cn4_167.pdf>lastaccessed 25 June 2021. 
Taken more broadly, international law, at the time of Lauterpacht's work, was perceived in the area of treaty interpretation as a recipient of private law analogies relating to contract interpretation; the reverse capacity - important for this investigation - of being a donor of interpretative principles was far beyond any contemplation. And while various other scholars of the time, including Wilfred Jenks, dared to pose the question on the potential relevance of the rules of treaty interpretation (well before their own codification in the VCLT) for the interpretation of contracts that appear in a public international law setting, before the $\mathrm{PCIJ},{ }^{30}$ in practice, those rules were not relied upon, neither in the PCIJ, nor in subsequent ICJ jurisprudence, even after the VCLT emerged in 1969 and defined the interpretative practices of many public international law courts. ${ }^{31}$ Hersch Lauterpacht himself had an opportunity to reflect on the hypothetical question of the reverse relevance of rules on treaty interpretation regarding the interpretation of contracts that appear in a public international law setting. The opportunity arose in 1957 when Lauterpacht acted as an ICJ judge ${ }^{32}$ in Certain Norwegian Loans (France v. Norway). In the Separate Opinion, he concluded without hesitation that it was the proper national law of the loan agreements - Norwegian law - that primarily defined how these contracts should be construed. ${ }^{33}$ To international law, Lauterpacht attributed only a corrective role because ' $[t]$ he question of conformity of national legislation with international law is a matter of international law'. ${ }^{34}$ The idea of a possible reliance on the rules of treaty interpretation was not raised at all.

30 Clarence Wilfred Jenks, The Prospects of International Adjudication (Stevens \& Sons 1964) 599 .

31 In the paper 'Disengagement from Domestic Law in Contract Interpretation in Public International Law Context' I analysed contract-related jurisprudence of PCIJ and ICJ and came to the conclusion that the World Court has not (expressly) relied on rules of treaty interpretation while approaching contracts. The paper was presented at the Workshop 'Engaging with Domestic Law in International Adjudication: Fact-finding or Transnational Law-Making?' at the University of Amsterdam on 1 March 2019.

32 Hersch Lauterpacht served as a judge of the ICJ in the period 1955-1960 - Elihu Lauterpacht, The Life of Hersch Lauterpacht (Cambridge University Press 2010) 373-422.

33 Sir Hersch Lauterpacht justified relevance of national law in the following words: " $[u] n$ doubtedly, the question of the interpretation of the contracts between the Norwegian State and the bondholders is primarily a question of Norwegian law. It is not disputed that the Norwegian law is the proper law of the contract and that it is for the Norwegian courts to decide what Norway had actually promised to pay' - see Separate opinion of Sir Hersch Lauterpacht in Case of Certain Norwegian Loans, 37.

34 Ibid. 32. Lauterpacht's recognition in a subsequent ICJ case, in a different context, of the existence of common interpretative principles for contracts and treaties 'relevant to all legal instruments, of whatsoever description' does not illustrate a change of view, but serves rather as a reiteration of the similarity he initially raised in 1927 in his Private Law 
Nevertheless, there may be an explanation for the at least hypothetical readiness of the treaty-based tribunals to rely on treaty interpretation rules for contract interpretation in investment treaty arbitration. In their decisionmaking, treaty-based tribunals extensively and routinely apply rules on treaty interpretation. Tribunals have not only become familiar with the interpretative paradigm of the VCLT, they have become accustomed to it too. Their overall legal argumentative technique may be viewed as being more receptive to public law reasoning - national and international - than private national law reasoning. ${ }^{35}$ Because of the various signs of these influences, it is unsurprising that private law critics of investment treaty arbitration are on the rise. ${ }^{36}$ Instead of outright negation, the extension of the interpretative paradigm of the VCLT to contract interpretation, accordingly, merits investigation. And that is what this section will do.

To start with it is interesting to look at practice. Are there any cases in which the tribunal relied on the interpretative provisions of the VCLT for contract interpretation? On a thorough inquiry, at least one case can be identified. Before proceeding to the analysis of this case, it is important to understand what the interpretative provisions of the VCLT are and how different they are, if at all, from the interpretative provisions in national laws. The VCLT contains

Analogies: With Special Reference to International Arbitration - see Admissibility of hearings of petitioners by the Committee on South West Africa (1956) (Advisory Opinion) [1956] ICJ Rep 23, 47-48.

35 On the role of the paradigm of public law in the reasoning of investment treaty tribunals, see Stephan W Schill, 'The Public Law Paradigm in International Investment Law' (EJIL: Talk!, 3 December 2013) <www.ejiltalk.org/the-public-law-paradigm-ininternational-investment-law> accessed 25 June 2021; Stephan W Schill, 'The Impact of International Investment Law on Public Contracts' in Mathias Audit and Stephan W Schill (eds), Transnational Law of Public Contracts (Bruylant 2016) 231-258. On the role of analogies drawn from public national laws, see Daniel Peat, 'International Investment Law and the Public Law Analogy: The Fallacies of the General Principles Method' (2018) 9(4) Journal of International Dispute Settlement 654. For the analogies drawn in legal reasoning from commercial arbitration and from public international law, see also Gus Van Harten, Investment Treaty Arbitration and Public Law (Oxford University Press 2008) 121-151. For a broad perspective of competing paradigms in understanding international investment that included views from public international law, international commercial arbitration, public law, trade law and human rights, see Anthea Roberts, 'Clash of Paradigms: Actors and Analogies Shaping the Investment Treaty System' (2013) 107(1) American Journal of International Law 45.

36 Zachary Douglas, The International Law of Investment Claims (Cambridge University Press 20o9) 6-38; Julian Arato, 'The Private Law Critique of International Investment Law' (2019) 113(1) American Journal of International Law 1; Julian Arato, 'The Logic of Contract in the World of Investment Treaties' (2016) 58(2) William \& Mary Law Review 351. 
interpretative provisions in three articles. Article $3^{1}$ deals with the general rules of interpretation providing that interpretation shall be 'in good faith in accordance with the ordinary meaning to be given to the terms of the treaty in their context and in the light of its object and purpose'. Article 32 contains the supplementary rules of interpretation in the form of 'the preparatory work of the treaty and the circumstances of its conclusion.' Article 33 clarifies approaches for linguistic discrepancies by specifying the equal authority of the text in each language in the absence of the specific provisions in the treaty to the contrary or the parties' agreement as to which text shall prevail.

The overall operation of the interpretative rules raises an ongoing debate. Articles $31-32$ triggered numerous publications discussing whether they set clear stages for interpretative exercise, ${ }^{37}$ how they deal with intertemporal aspects, ${ }^{38}$ what the role of other uncodified rules of interpretation are, ${ }^{39}$ and

37 For instance, Christian Djeffal, Static and Evolutive Treaty Interpretation: A Functional Reconstruction (Cambridge University Press 2016); Richard Gardiner, Treaty Interpretation (2nd edn, Oxford University Press 2015); Tarcisio Gazzini, Interpretation of International Investment Treaties (Hart Publishing 2016); Ulf Linderfalk, On the Interpretation of Treaties: The Modern International Law as Expressed in the 1969 Vienna Convention on the Law of Treaties (Springer 2007); Michael Waibel, 'Demystifying the Art of Interpretation' (2011) 22 European Journal of International Law 571.

38 For instance, on intertemporal aspects of treaty interpretation and evolutive interpretation, see Eirik Bjørge, The Evolutionary Interpretation of Treaties (Oxford University Press 2014); Giovanni Distefano, 'Linterpretation évolutive de la norme internationale' (2011) 115(2) Revue Générale de Droit International Public 373; Julian Arato, 'Subsequent Practice and Evolutive Interpretation: Techniques of Treaty Interpretation over Time and Their Diverse Consequences' (2010) 9(3) Law \& Practice of International Courts and Tribunals 443; Malgosia Fitzmaurice, 'Dynamic (Evolutive) Interpretation of Treaties Part I' (2008) 21(2) Hague Yearbook of International Law 101; Marko Milanovic, 'The ICJ and Evolutionary Treaty Interpretation' (EJIL: Talk!, 14 July 2009) <https://www.ejilt alk.org/the-icj-and-evolutionary-treaty-interpretation/> accessed 25 June 2021; Osamu Inagaki, 'Evolutionary Interpretation of Treaties Re-examined: The Two-Stage Reasoning' (2015) 22(2-3) Journal of International Cooperation Studies 127; Pierre-Marie Dupuy, 'Evolutionary Interpretation of Treaties: Between Memory and Prophecy' in Enzo Cannizzaro (ed), The Law of Treaties Beyond the Vienna Convention (Oxford University Press 2011) 123; Rudolf Bernhardt, 'Evolutive Treaty Interpretation, Especially of the European Convention on Human Rights' (1999) 42 German Yearbook of International Law 11; Sondre Torp Helmersen, 'Evolutive Treaty Interpretation: Legality, Semantics and Distinctions' (2013) 6(1) European Journal of Legal Studies 127; Ulf Linderfalk, 'Doing the Right Things for the Right Reason - Why Dynamic or Static Approaches Should be Taken in the Interpretation of Treaties' (2008) 10(2) International Community Law Review 109.

39 Michael Waibel, 'The Origins of Interpretative Canons in Domestic Legal Systems' in Joseph Klinger and others (eds), Between the Lines of the Vienna Convention? Canons of Construction and Other Interpretive Principles in Public International Law (Kluwer Law 
some others. Article 33, on linguistic discrepancies, receives somewhat less attention. ${ }^{40}$

Raising itself disagreement in relation to its own interpretation, Articles $3^{1-}$ 32 shall not accordingly form an illusion about their magic capacity to represent universal interpretative rules, which, as and when applied to contracts, by analogy or by extension, mute all the contrasts/differences to contract interpretation across national laws (as discussed in Chapter 2, the mission of neutralising discrepancies in contract interpretation across jurisdictions for various private law harmonisers became somewhat challenging). The described focus of interpretative rules on consent captures the similarity in contract and treaty interpretation on a very superficial level and does not react to the plurality of important distinctions as to how the meaning of consent is in fact extracted from a contract and from treaties. It is accordingly not surprising that the existent general similarity between contract interpretation and treaty interpretation that illuminated academic work of the previous century prior to the emergence of the VCLT almost disappeared from the radar of contemporary scholars.$^{41}$ Not only are we better informed now on the distinctions between contract interpretation in various national laws and the difficulties to reflect common rules in uniform transnational sources on harmonisation, more analysis has become available on the distinctions between treaty interpretation across various international law subfields. The fragmentation of international law and the growing of the somewhat isolated interpretative communities sharpened differences in treaty interpretation within investment, trade, financial, monetary, human rights and other regimes. ${ }^{42}$ Furthermore, there seems to

International 2018) 25-46. See also other chapters in Joseph Klingler and others (eds), Between the Lines of the Vienna Convention? Canons of Construction and Other Interpretive Principles in Public International Law (Kluwer Law International 2018).

40 For instance, Oliver Dörr and Kirsten Schmalenbach (eds), Vienna Convention on the Law of Treaties: A Commentary (2nd edn, Springer 2018) 635-651; Peter Germer 'Interpretation of Plurilingual Treaties: A Study of Article 33 of the Vienna Convention on the Law of Treaties' (1970) 11 Harvard International Law Journal 400, 400-427; Christopher B Kuner, 'The Interpretation of Multilateral Treaties: Comparison of Texts versus the Presumption of Similar Meaning' (1991) 40(4) International and Comparative Law Quarterly 953, 953-964.

41 Some references nevertheless may still be found - see Eirik Bjørge, The Evolutionary Interpretation of Treaties (Oxford University Press 2014) 99-105.

42 Michel Waibel, 'Interpretive Communities in International Law' in Andrea Bianchi and others (eds), Interpretation in International Law (Oxford University Press 2015) 147-165. For various aspects of the application of VCLT to the interpretation of treaties in the subfields of international law, see, for instance, Christoph Schreuer, 'Diversity and Harmonization of Treaty Interpretation in Investment Arbitration' in Malgosia Fitzmaurice and others (eds), Treaty Interpretation and Vienna Convention on the Law of Treaties: 30 Years 
be an increasing interest in interpretative rules of international law in relation to sources other than treaties. Interpretation of customary rules of international law appears increasingly in focus. ${ }^{43}$ The described distinctions to a certain extent resemble differences in contract interpretation under applicable national regimes ${ }^{44}$ and similar distinctions in statutory interpretation across jurisdictions and even across federal parts. ${ }^{45}$ To put it simply, neither treaty interpretation nor contract interpretation are monochrome and homogenous concepts; they are concepts that welcome to various extents, under their umbrella, a range of distinct approaches.

Further, comparison of Article 31 and Article 32 of the VCLT with rules on contract interpretation in national laws reveals numerous rather sensitive distinctions between them. For instance, for English law, not only a reference to good faith in Article 31 will serve as a red flag; a reference to the object and purpose of the document/treaty will be perceived as an open invitation to investigate subjective intent, something that English contract law tries to diminish. ${ }^{46} \mathrm{~A}$ reference to any subsequent practice of the parties in the application of the document will turn equally rebellious against fundamental

on (Martinus Nijhoff 2010) 129-151; J Romesh Weeramantry, Treaty Interpretation in Investment Arbitration (Oxford University Press 2012); Isabelle Van Damme, Treaty Interpretation by the WTO Appellate Body (Oxford University Press 2009). Georges AbiSaab, 'The Appellate Body and Treaty Interpretation', in Malgosia Fitzmaurice and others (eds), Treaty Interpretation and Vienna Convention on the Law of Treaties: 30 Years on (Martinus Nijhoff 2010) 97-109.

43 Alexander Orakhelashvili, The Interpretation of Acts and Rules in Public International Law (Oxford University Press 2008) 496-510. See also ERC projects, 'The Rules on Interpretation of Customary International Law' <https://cordis.europa.eu/project/rcn/ 212805/en> accessed 25 June 2021 and Jean d'Aspremont, 'The Four Lives of Customary International Law' (2019) 21 (3-4) International Community Law Review 229, 229-256.

44 See Chapter 2.

45 On distinctions in statutory interpretation, see Stephan Vogenauer, 'Statutory Interpretation' in Jan M Smits (ed), Encyclopedia of Comparative Law (2nd edn, Edward Elgar Publishing 2012) 826-838; Christopher Hunt and others, Legislating Statutory Interpretation: Perspectives from the Common Law World (Thomson Reuters 2018).

46 See Chapter 2. English contract law traditionally has a restrictive approach to good faith as undermining predictability in contractual relations. Even for relational types of contracts that usually imply considerations of good faith in civil law jurisdictions, English courts are somewhat sceptical. In Globe Motors Inc v. TRW Lucas Variety Electric Steering $L t d$, the Court of Appeal rejected the relevance of good faith consideration as a general principle and emphasised a need for more clear incorporation: 'the implication of a duty of good faith will only be possible where the language of the contract, viewed against its context, permits it. It is thus not a reflection of a special rule of interpretation for this category of contract.' - Globe Motors Inc v TRW Lucas Variety Electric Steering Ltd, [2016] EWCA Civ 396. 
principles of interpretative rules under English contract law that prioritise text. ${ }^{47}$ In fact, as addressed in Chapter 1, a treaty-based tribunal had an opportunity to contrast these interpretative approaches under international law along the same lines in Azpetrol v. Azerbaijan, emphasising the role of subsequent practice and travaux préparatoires as the most sharp distinctions in approaches. ${ }^{48}$ Equally, however unsatisfactory Articles 31 and 32 may be, if assessed from the civil law tradition of French law, even if one may align general rules of treaty interpretation with that of contract interpretation under Article 1188 of the French Civil Code, other sensitive distinctions nevertheless emerge. An interpretation of a reasonable man in the same situation ${ }^{49}$ as a default interpretative rule under the French law and the absence of the precise rule in the VCLT may disappoint a French interpreter relying on the VCLT for contract interpretation. Furthermore, a lack of more specific provisions in the VCLT, that are available in French law regarding interpretation in favour of certain parties - the debtor or the party that acceded to a document/contract ${ }^{50}$ may turn out to be equally sensitive distinctions.

If one were to attempt to reconstruct whether a reference to good faith in the VCLT is in fact a transplant from the national laws making the VCLT closer to a civil law approach to contract interpretation, one would be equally disappointed. Rather than bringing the corrective function of good faith considerations into civil law tradition, a reference to good faith appeared primarily in the VCLT as a manifesto directed at interpreters who have to interpret in good faith. The origin of the appearance of good faith in the VCLT and other

47 As a general rule, English contract law does not permit consideration of the subsequent conduct of the parties for interpretation. An exception to the general rule can take place when an original intent has to be established when a contract is part oral and part written - Brian Maggs v. Guy Marsh [2006] EWCA Civ 1058. Another exception comes in cases of rectification as identified in a leading case on contract interpretation Investors Compensation Scheme Ltd. v. West Bromwich Building [1998] 1 WLR 898.

48 Azpetrol International Holdings B.V., Azpetrol Group B.V. and Azpetrol Oil Services Group B.V. v. The Republic of Azerbaijan, ICSID Case No. ARB/o6/15, Award dated 8 September 2008, para 62-65.

49 Article 1188 (2) of the French Civil Code in force as of 1 October 2016 provides: 'Lorsque cette intention ne peut être décelée, le contrat s'interprète selon le sens que lui donnerait une personne raisonnable placée dans la même situation.' [When the intention cannot be defined, the contract shall be interpreted in the sense that would be given to it by a reasonable person in the same situation.]

50 Article 1190 of the French Civil Code in force as of 1 October 2016 specifies: 'Dans le doute, le contrat de gré à gré s'interprète contre le créancier et en faveur du débiteur, et le contrat d'adhésion contre celui qui l'a proposé.' [In case of doubt, a contract concluded in negotiations is interpreted against the creditor and in favour of the debtor, and the contract of adhesion against the one who proposed it]. 
considerations associated with good faith are addressed in more detail in the section dealing with general principles of law below.

Viewed from contract law perspectives of any jurisdiction, it would be unlikely that the interpretative provisions of Article $31-32$ of the VCLT would settle all differences. Should they be able to do so, it would have certainly been the VCLT that influenced the drafting efforts on interpretative provisions in transnational sources - such as the UPICC. The history of the UNIDROIT text however demonstrates that it was rather the CISG than the VCLT that affected interpretative provisions. In turn, and as discussed in the subsequent section on the CISG, the VCLT has not informed its interpretative provisions and was raised as an argument for the overall exclusion of interpretative principles from the CISG.

While not responding to expectations on contract interpretation under national laws, interpretative provisions of the VCLT bring nevertheless some novelty which is not routinely found in national laws - rules on linguistic discrepancy. ${ }^{51}$ Article 33 suggests that if no preference is established either by a treaty or by the parties' agreement, the differences should be attempted to be removed using general rules of interpretation established by Articles $3^{11}$ and $3^{2}$ of the VCLT. If this exercise does not remove discrepancy, a harmonising interpretation reconciling both texts with a view to a treaty object and purpose shall be adopted.

The approach to dealing with linguistic discrepancy substantially differs from that suggested later by the UPICC. The VCLT suggests to attempt to remove discrepancies primarily by teleological and purposive interpretation without giving any single language predetermined priority. The UPICC in turn favours the initial or original language in which a provision or the whole contract were drafted. ${ }^{52}$

Linguistic practice existent in treaty drafting at the time of the work on the VCLT largely explains the reluctance of Article 33 to rely on the language in which a treaty is originally drafted. At that time, the predominant part of

$5^{1} \quad$ Ingeborg Schwenzer and others, Global Sale and Contract Law (Oxford University Press 2012) 296-297, para. 26.18 .

52 Article 4.7 of the UPICC provide as follows: 'Where a contract is drawn up in two or more language versions which are equally authoritative there is, in case of discrepancy between the versions, a preference for the interpretation according to a version in which the contract was originally drawn up.' See also a commentary on the provision - Stefan Vogenauer, 'Article 4.7 ' in Stefan Vogenauer and Jan Kleinheisterkamp (eds), Commentary on the UNIDROIT Principles of International Commercial Contracts (PICC) (Oxford University Press 2009) 531-533. 
treaties was drafted in French. ${ }^{53}$ A reference to the original language would almost automatically give a preference to the French language. The Special rapporteur explained the undesirability to prefer a single language and the appropriateness of reconciling and only thereafter applying the general rules of interpretation as follows:

Plurilingual in expression, the treaty remains a single treaty with a single set of terms the interpretation of which is governed by the same rules as unilingual treaties, that is, by the rules set out in articles $7 \mathrm{O}^{-} 73$ [now articles $31-33]$...

The plurilingual form of the treaty does not justify the interpreter in simply preferring one text to another and discarding the normal means of resolving an ambiguity or obscurity on the basis of the objects and purposes of the treaty, travaux préparatoires, the surrounding circumstances, subsequent practice, etc. On the contrary, the equality of the texts requires that every effort should first be made to reconcile the texts and to ascertain the intention of the parties by recourse to the normal means of interpretation. ${ }^{54}$

It might be tempting, accordingly, to see political considerations behind the rules in the VCLT dealing with linguistic discrepancy and practical considerations behind the UPICC provision.

A single attempt so far to engage with the VCLT for contract interpretation evidences precisely a reliance on Article 33 of the VCLT when dealing with linguistic discrepancy. ${ }^{55}$ The tribunal in the Eurotunnel case found that even though 'the Concession Agreement is not a treaty, it is an agreement governed by international law, an "international contract", and that international law principles of interpretation are to be applied'; ${ }^{56}$ furthermore, with reference to the parties' agreement, the tribunal clarified that 'the principles of interpretation laid down in the Vienna Convention on the Law of Treaties

53 Oliver Dörr and Kirsten Schmalenbach (eds), Vienna Convention on the Law of Treaties: A Commentary (2nd edn, Springer 2018) 635, 637 .

54 Sir Humphrey Waldock, "Third Report on the Law of Treaties, by Sir Humphrey Waldock, Special Rapporteur' (A/CN.4/167, 1964) 2 Yearbook of the International Law Commission 63-64 <http://legal.un.org/ilc/documentation/english/a_cn4_167.pdf> last accessed 25June 2021.

55 This chapter does not deal with the unconscious reliance on interpretative rules in the VCLT that could have taken place in the analysis of those tribunals that were more affected by the public international law paradigm. The Eurotunnel Arbitration, Partial Award of 30 January 2007, para. 92. 
("Vienna Convention") are declaratory also for agreements between States and private parties under international law and should be applied to resolve any discrepancies. ${ }^{57}$ Relying on Article 33, the tribunal, consisting primarily of public international law lawyers, ${ }^{58}$ chose to emphasise its customary character. ${ }^{59}$

While Eurotunnel was primarily a contract-based case, a public international law source - the Treaty of Canterbury 60 - constituted an important part of its legal framework. ${ }^{61}$ The treaty backed up the concession supplying relevant

57 Ibid.

$5^{8}$ The tribunal was composed of James Crawford, L Yves Fortier, Gilbert Guillaume, Lord Millett, and Jan Paulsson. Nowadays when many lawyers practise both public international law and international commercial arbitration, it may be difficult to attribute to a profile an exclusive or dominant specialisation in public international law. At the same time no difficulty arises to see a public international law highlight for this panel. James Crawford was Former Whewell Professor of International Law of the University of Cambridge, judge of the ICJ from 2014-2021; L Yves Fortier is a former Canadian diplomat, Gilbert Guillaume is a former Judge and President of the ICJ and Member of the Institute of International Law; Lord Millet is a non-permanent judge of the Hong Kong Court of Final Appeal and a former Lord of Appeal in Ordinary and barrister of the United Kingdom; Jan Paulsson, while being seen more in international commercial arbitration, served also in other tribunals including as President of the World Bank Administrative Tribunal and President of the EBRD Administrative Tribunal.

59 The Eurotunnel Arbitration, Partial Award of 30 January 2007, fn 242: 'The International Court recognized the customary character of Article 33(4) of the Vienna Convention in the LaGrand case' (Germany v. United States of America) ICJ Reports 2001, 466, 502 (para. 101).

6o The Treaty concerning the Construction and Operation by Private Concessionaires of a Channel Fixed Link was signed at Canterbury on 12 February 1986. Following ratification by both States it entered into force on 24 July 1987.

61 The tribunal explained the limits of its jurisdiction and relevance of the Treaty of Canterbury as follows: 'The conclusion that the Tribunal lacks jurisdiction to consider claims for breaches of obligations extrinsic to the provisions of the Concession Agreement (and the Treaty as given effect by the Concession Agreement) does not mean that the rules of the applicable law identified in Clause 40.4 are without significance. They instruct the Tribunal on the law which it is to apply in determining issues within its jurisdiction. They provide the legal background for the interpretation and application of the Treaty and the Concession Agreement, and they may well be relevant in other ways. But it is the relationship between the Principals and the Concessionaires as defined in Clause 41.1 on which the Tribunal is called to pronounce ... To conclude, the Tribunal's jurisdiction is limited to claims which implicate the rights and obligations of the Parties under the Concession Agreement as defined in Clause 41.1. Thus, the source and the only source of the Parties' respective rights and obligations with which the Tribunal is concerned is (a) the Treaty (but only insofar as it is given effect to by the Concession Agreement) and (b) the Concession Agreement (whether or not it goes beyond merely giving effect to the Treaty).' - The Eurotunnel Arbitration, Partial Award of 30 January 2007, para. 151, 153 . 
rules that affected the jurisdiction and substance of the dispute. At the same time, the treaty did not serve as an independent cause of action in the dispute and was relied upon through a concession agreement. ${ }^{62}$ In the absence of any refined/clear examples of cases of investment treaty arbitration which relied on the interpretative provision in the VCLT, and with necessary caveats, the Eurotunnel is used here for illustrative purposes.

The concession agreement that appeared central to the dispute was entered into by two entities of the Eurotunnel group and the governments of France and the United Kingdom for the construction of the Fixed Link between France and the United Kingdom. Claimants said that they had suffered losses because of the incursions caused by refugees who illegally attempted to travel to the United Kingdom, and claimed that both states had failed to prevent said incursions. Linguistic discrepancies marked one of the most important provisions of the concession - clause 2.1 - relating to the nature of undertakings assumed by the states vis-à-vis concessioner, either as an obligation of coordination, or as an obligation individually and, where necessary, collectively to take appropriate measures for the development, financing, construction and operation of the Fixed Link in accordance with the concession agreement. Relying on Article 33 of the VCLT and equating pre-contractual correspondence and negotiations to travaux préparatoires, ${ }^{63}$ the tribunal concluded that clause 2.1 related not only to coordination undertakings, but also to individual and collective measures, and that the principals under the concession agreement had failed to observe said undertakings.

Even though the contract in question involved states as contracting parties and even though the tribunal predominantly consisted of public international law lawyers, this alone does not suffice to justify reliance on the VCLT for interpreting a contract. A thorough investigation reveals that it was rather the parties' agreement that made a reliance technically possible. ${ }^{64}$ The parties did not dispute the relevance of Article 33, most likely because the provision represents a rather unique set of rules that expressly govern issues of linguistic discrepancies which states are familiar with. While one can no doubt agree with the proposition that contractual laws are more advanced to address a broad variety of peculiarities surrounding contracts, contractual multilingualism does not however turn as a rule into an issue for express regulation in national laws.

62 The tribunal, for instance, found that two states were in a breach of obligations under the Treaty of Canterbury 'as given effect by the Concession Agreement' - The Eurotunnel Arbitration, Partial Award of 30 January 2007, para. 395 (1).

63 Ibid. para. 94.

64 Ibid. para. 92. 
Parties usually distribute risks associated with language discrepancies across their contracts by including provisions expressly setting which linguistic version of a contract should prevail in the case of discrepancy. In the absence of this provision, such as in the concession agreement for the Eurotunnel, as well as in the absence of specific regulation in national law, tribunals can do nothing but resolve issues circumstantially. ${ }^{65}$ Stephan Vogenauer acknowledges an innovative provision on linguistic discrepancy, commenting on the interpretative rules in the UPICC, which while somewhat different from the VCLT's approach ${ }^{66}$ could also potentially serve as a basis for contract interpretation, but it failed, possibly because of its applicability to 'commercial' contracts. ${ }^{67}$ A reliance on the provisions on linguistic discrepancy may be a ground to consider that the VCLT was not applied as a source of international law, but rather as a reflection of certain interpretative rules to which both parties expressed agreement after the dispute arose - closer to a transnational source than a public international law instrument proper.

That it was a rather unique coincidence of factors that led to the application of Article 33 (4) of the VCLT to contract interpretation in Eurotunnel is indirectly supported by other investment treaty arbitration cases in which arbitrators involved in Eurotunnel acted and in which they had to interpret contracts. ${ }^{68}$ There is no single case with the participation of these arbitrators which demonstrates any

65 Schlechtriem \& Schwenzer's Commentary on the UN Convention on the International Sale of Goods (CISG) provides a helpful overview of factors that might assist to resolve language discrepancies, and which might be equally applicable to the context of analysis under national laws. The spectrum of factors includes trade or industry usages, the context of standard contracts, established practice between the parties, the official language in the place of business, etc. - see Ingeborg Schwenzer (ed), Schlechtriem \& Schwenzer Commentary on the UN Convention on the International Sale of Goods (4th edn, Oxford University Press 2016) 164-166.

66 Stefan Vogenauer, 'Article 4.7' in Stefan Vogenauer and Jan Kleinheisterkamp (eds), Commentary on the UNIDROIT Principles of International Commercial Contracts (PICC) (Oxford University Press 2009) 531.

67 For a discussion of the binary nature of commercial and investment contracts see below.

68 For clarity it should be noted that it appears from the public sources that James Crawford, Jan Paulsson, Gilbert Guillaume, L Yves Fortier and The Rt. Hon. Lord Millett - arbitrators involved in the Eurotunnel case - have not sat all on the same panel thereafter and neither of the cases in which they acted and interpreted contracts in fact related to contracts where more than one party was a state, and no linguistic discrepancy in the text of a contract appeared either. James Crawford acted as an arbitrator/member of an annulment committee in the investment treaty arbitration involving contract interpretation in the cases as follows: SGS Société Générale de Surveillance S.A. v. Republic of the Philippines, ICsid Case No. ARB/o2/6; Waste Management, Inc. v. United Mexican States ("Number 2"), ICSID Case No. ARB(AF)/oo/3; MTD Equity Sdn. Bhd. and MTD Chile 
attempt to rely on the VCLT as a declaration of the relevant interpretative principles for contract interpretation. Somewhat distant similarities may be, however, found in Lemire v. Ukraine (II), with participation of one of the arbitrators from the Eurotunnel case - Jan Paulsson. Although not referring to the VCLT, the tribunal in Lemire v. Ukraine (II) considered the parties' failure to expressly choose which law was to be applicable in the settlement agreement as a 'negative choice' of national law and a proxy to rely on transnational principles. ${ }^{69}$

S.A. v. Republic of Chile, ICSID Case No. ARB/o1/7 (Annulment), Compañiá de Aguas del Aconquija S.A. and Vivendi Universal S.A. v. Argentine Republic, ICSID Case No. ARB/97/ 3 (Annulment); CMS Gas Transmission Company v. The Argentine Republic, ICsID Case No. ARB/o1/8 (Annulment). Jan Paulsson acted as an arbitrator in the investment treaty arbitration involving contract interpretation in Desert Line Projects LLC $v$. The Republic of Yemen, ICSID Case No. ARB/05/17; Joseph Charles Lemire v. Ukraine, ICSID Case No. ARB/o6/18; Generation Ukraine, Inc. v. Ukraine, ICSID Case No. ARB/oo/9; Adem Dogan v. Turkmenistan, ICSID Case No. ARB/o9/9; Vannessa Ventures Ltd. v. Bolivarian Republic of Venezuela, ICSID Case No. ARB(AF)O4/6. Gilbert Guillaume acted as an arbitrator/ member of an annulment committee in the investment treaty arbitration involving contract interpretation in Swisslion DOO Skopje v. The former Yugoslav Republic of Macedonia, ICSID Case No. ARB/og/16, CMS Gas Transmission Company v. The Argentine Republic, ICsid Case No. ARb/o1/8 (Annulment), Siemens A.G. v. The Argentine Republic, ICSID Case No. ARB/o2/8 (Annulment), MTD Equity Sdn. Bhd. and MTD Chile S.A. v. Republic of Chile, ICSID Case No. ARB/o1/7 (Annulment), Venezuela Holdings, B.V., et al (case formerly known as Mobil Corporation, Venezuela Holdings, B.V., et al.) v. Bolivarian Republic of Venezuela, ICSID Case No. ARB/o7/27. L Yves Fortier acted as an arbitrator/member of an annulment committee in the investment treaty arbitration involving contract interpretation in Bureau Veritas, Inspection, Valuation, Assessment and Control, BIVAC B.V. v. The Republic of Paraguay, ICsid Case No. ARB/o7/9; Eureko B.V.v. Republic of Poland; Ron Fuchs v. The Republic of Georgia; Ioannis Kardassopoulos v. The Republic of Georgia, ICsID Case No. AR B / 05/18; Gemplus S.A., SLP S.A., Gemplus Industrial S.A. de C.V.v. The United Mexican States, ICSID Case No. ARB (AF)/o4/3; Talsud S.A.v. The United Mexican States, ICSID Case No. ARB(AF)/o4/4; Hulley Enterprises Limited (Cyprus) v. The Russian Federation, UNCITRAL, PCA Case No. AA 226; Occidental Petroleum Corporation and Occidental Exploration and Production Company v. The Republic of Ecuador, ICSID Case No. ARB/o6/11; PSEG Global, Inc., The North American Coal Corporation, and Konya Ingin Electrik Üretim ve Ticaret Limited Sirketiv. Republic of Turkey, ICSID Case No. ARB/ o2/5; Bernhard von Pezold and Others v. Republic of Zimbabwe (ICSID Case No.ARB/10/15); Ampal-American Israel Corporation and others v. Arab Republic of Egypt, ICSID Case No. ARB /12/11, Oko Pankki Oyj, VTB Bank (Deutschland) AG and Sampo Bank Plcv. The Republic of Estonia, ICsid Case No. ARB/o4/6, ConocoPhillips Petrozuata B.V., ConocoPhillips Hamaca B.V. and ConocoPhillips Gulf of Paria B.V. v. Bolivarian Republic of Venezuela, ICsid Case No. ARB/o7/3o, Saluka Investments B.V.v. The Czech Republic, UnCITRAL, Khan Resources Inc., Khan Resources B.V., and Cauc Holding Company Ltd. v. The Government of Mongolia and Monatom Co., Ltd. (PCA Case No.2011-o9), unCitral, Compañiá de Aguas del Aconquija S.A. and Vivendi Universal S.A. v. Argentine Republic, ICSID Case No. ARB/97/3 (Annulment).

69 Joseph Charles Lemire v. Ukraine, ICSID Case No. ARB / O6/18, Decision on Jurisdiction and Liability dated 14 January 2010, para. 111. 
It is further noteworthy that no other analysed case in investment treaty arbitration dealing with issues relating to linguistic discrepancies in contracts evidences a reliance on the VCLT. The issue of linguistic discrepancy has arisen in at least two cases: Werner Schneider, acting in his capacity as insolvency administrator of Walter Bau Ag (In Liquidation) $v$. The Kingdom of Thailand ${ }^{70}$ and Caratube International Oil Company LLP and Devincci Salah Hourani v. Republic of Kazakhstan..$^{71}$ In contrast to Eurotunnel, the parties in these cases expressly allocated risks between themselves in relation to linguistic discrepancy, either by agreeing in a straightforward manner which language prevailed from the outset, ${ }^{72}$ or by providing a more complex mechanism which, on the one hand, would emphasise the equal nature of drafts in both languages, while on the other hand retaining one language as an ultimate recourse. ${ }^{73}$ In Werner Schneider, acting in his capacity as insolvency administrator of Walter Bau Ag (In Liquidation) v. The Kingdom of Thailand, the tribunal, with the assistance of the Thai arbitrator on the panel, reconfirmed that the terms in question in the dominant Thai language did not substantially differ from the English variant. In this regard, the tribunal exclusively relied on the contractual provision on prevalence of one language and did not find it necessary to corroborate the finding by reference to the law applicable to a contract. In Caratube International Oil Company LLP and Devincci Salah Houraniv. Republic of Kazakhstan, the tribunal faced a more complicated task.

$70 \quad$ Werner Schneider, acting in his capacity as insolvency administrator of Walter Bau Ag (In Liquidation) $v$. The Kingdom of Thailand, UNCITRAL (formerly Walter Bau AG (in liquidation) $v$. The Kingdom of Thailand).

71 Caratube International Oil Company LLP and Devincci Salah Hourani v. Republic of Kazakhstan, ICSID Case No. ARB $/ 13 / 13$.

72 Werner Schneider, acting in his capacity as insolvency administrator of Walter Bau Ag (In Liquidation) v. The Kingdom of Thailand, UNCITRAL (formerly Walter Bau AG (in liquidation) v. The Kingdom of Thailand), Award dated 1 July 2009, para. 7.13-7.14. Clause 35.7, paragraph two, of the Concession Agreement reads in part: 'This Concession Agreement is executed in Thai and English languages in duplicate with identical wording and the Thai version shall govern in the event of discrepancies.'

73 Caratube International Oil Company LLP and Devincci Salah Hourani v. Republic of Kazakhstan, ICSID Case No. ARB/13/13, Award dated 27 September 2017, para. 6oo. The contract provided: '30.1 The text of this Contract shall be made in the State, Russian and English languages and all signed versions shall have equal legal force. 30.2 In case of any inconsistency or conflicts among the versions, the versions of the text in Russian and English shall be used to resolve such inconsistency or conflict and both texts will be considered on an equal basis; provided, however, that in case of any conflict between the English and Russian texts in any arbitration under this Contract, the arbitration panel shall conform the two texts to the extent possible and shall revert to the Russian text for the interpretation of any specific provisions, using general principles of fairness.' 
In deciding whether the contract at stake represented the parties' agreement to treat one of the parties to be a foreign one for the purpose of the ICSID Convention, ${ }^{74}$ the tribunal had to resolve the parties' disagreements over the effects of a provision specifying the Lebanese nationality of the claimant in the Russian version. The tribunal was not in search of international or transnational rules, and based its analysis exclusively within the ambit of national law. A principle to consider is that an agreement as a whole under Kazakh law shaped the tribunal's interpretative exercise. ${ }^{75}$ The two cases again reaffirm the rather unique assembly of factors that surrounded the reliance on the VCLT in Eurotunnel.

Having seen the rather peculiar nature of reliance on the VCLT for solving linguistic discrepancy in Eurotunnel and the lack of other cases affirming the approach either in general or in relation to linguistic discrepancy, one may treat the words of Eirik Bjørge on there being a 'tendency', ${ }^{76}$ that Eurotunnel represents something rather premature. However, if assessed from a broader perspective, a proposition seems to resonate with Stephan Schill's observation on the reasoning of public international law in investment treaty arbitration. ${ }^{77}$ What remains certain is that the interpretative rules of the vCLT are not designed to be extended to contract interpretation and any reliance on them requires considerably more legitimising factors, including the parties' agreement. Furthermore, when applied through parties' agreement, the interpretative provisions of the VCLT lose their features as a source of international law and become mostly a reflection of a certain transnational regime that the parties made applicable to a particular contract.

74 Article 25(2)(b) of the ICSID Convention specifies parties' agreement as to nationality among one of the conditions for its jurisdiction. According to the provision, juridical persons are considered to have the 'nationality of another Contracting State' where, because of foreign control, the parties agreed to treat such person as a national of another Contracting State for the purposes of the ICsid Convention.

75 Caratube International Oil Company LLP and Devincci Salah Hourani v. Republic of Kazakhstan, ICSID Case No. ARB/13/13, Award dated 27 September 2017, para. 601.

76 Eirik Bjørge, 'Contractual' and 'Statutory' Treaty Interpretation in Domestic Courts?' in Helmut Phillipp Aust and Georg Nolte (eds), The Interpretation of International Law by Domestic Courts: Uniformity, Diversity, Convergence (Oxford University Press 2016) 53-54.

77 Stephan Schill notes: 'At the same time, investment tribunals are themselves increasingly breaking with the mind-set of international commercial arbitration by making use of argumentative techniques known from (national and international) public law, such as proportionality balancing, doctrines of deference, and comparative public law reasoning.' - see Stephan W Schill, 'In Defence of International Investment Law' in Marc Bungenberg and others (eds), European Yearbook of International Economic Law 2016 (Springer 2016) $328-329$. 


\subsubsection{International Investment Agreements}

As the critical legal framework for treaty-based disputes, international investment agreements (IIAS) are the next stop in the inquiry on the availability of specific rules of international law for contract interpretation. Because IIAs have emerged to provide an additional layer of protection for foreign investors in international law, but not to intervene in substantive regulation of investment activity in the respective states, an intuitive reaction would suggest that no interpretative provisions could be traced in their texts. A continuous failure of IIAs to solve the general intricacies of the contract-treaty divide makes it further rather unlikely that IIAs would expressly address contract interpretation. ${ }^{78}$ At the same time, treaty language is not put in stone. Even though states are signing less bilateral treaties than before, they continue to be actively engaged in megaregional trade treaties with investment chapters. ${ }^{79}$ Their choices seem to be more informed regarding new-generation IIAs and amendments of existing IIAs. ${ }^{80}$ This intensified dynamics makes it less certain that no specific provisions in IIAs on contract interpretation can be found in the texts of IIAs. In any event, an intuitive scepticism, even if reflecting the true picture, cannot substitute a proper investigation that has to be performed if one wants to find an answer.

The task to verify whether IIAs contain specific provisions that might shed light on contract interpretation is a demanding exercise. To answer properly, one has to deal with a large number of IIAs. ${ }^{81}$ In addition to concluded treaties,

78 Numerous unsettled issues that mark the contract-treaty divide in investment treaty arbitration, and which find their most dramatic development in the application of an umbrella clause and the FET standard, would not have taken place should IIAs resolve them expressly. The IsDs Academic Forum marks treaty silence on the contract-treaty divide as a reason for inconsistency in investment treaty arbitration ultimately compromising its overall legitimacy - see, ISDS Academic Forum, 'Concept Paper on Issues of ISDS Reform. Working Group No 3: Lack of Consistency and Coherence in the Interpretation of Legal Issues', para. 41, available at <https://www.cids.ch/images/Documents/AcademicForum/3_Inconsistency_-_WG3.pdf > accessed 25 June 2021.

79 UNCTAD, World Investment Report 2018: Investment and New Industrial Policies (UNCTAD/ WIR/2018) 88-103, available at <https://unctad.org/en/PublicationsLibrary/wir2018_ en.pdf $>$, accessed 25 June 2021; UNCTAD, World Investment Report 2019, 17-18, available at $<$ https://unctad.org/en/PublicationsLibrary/wir2o19_overview_en.pdf> accessed 25 June 2021.

8o UNCTAD, World Investment Report 2019: Special Economic Zones (UNCTAD/WIR/2019) 1920, available at <https://unctad.org/en/PublicationsLibrary/wir2o19_overview_en.pdf> accessed 25 June 2021; UNCTAD, 'IIA Issues Note No. 3, 2019. Taking Stock of IIA Reform: Recent Developments' 2-8, available at <https://unctad.org/en/PublicationsLibrary/diae pcbinf2019d5_en.pdf> accessed 25 June 2021.

81 Available at the UNCTAD Investment Policy Treaty Hub as of 30 January $2019<$ https:// investmentpolicyhub.unctad.org/IIA > accessed 25 June 2021. 
available model BITs also have to be considered because they may serve as an articulation of state policy and provide valuable insight into future changes in the wording of IIAs. ${ }^{82}$ In other words, the study has to engage with empirical analysis of the corpus linguistic of IIAs and model BITs.

To find an answer, this work has scrutinised the content of 1,525 IIAs (Annex VII) and 47 model BITs (Annex VIII) whose texts were available in English. As with all awards analysed in this book, only those treaties that were available as of 30 January 2019 were taken into account. Each and every treaty text was analysed first manually. Thereafter, all texts were run through verification with a computer search of key words. The following key words were used - 'contract', 'agreement', 'interpret' and 'interpretation'. All findings with these words were read again to double check that no omissions had occurred and no single provision was missed that could qualify under the rule or principle relevant for contract interpretation in investment treaty arbitration.

The study organised in this way found no rules or principles on contract interpretation. Of particular interest was the verification stage which revealed a broad range of treaty provisions expressly dealing with contracts or interpretation. In particular, contracts are frequently named in IIAs and Model BITs to define the term investment. ${ }^{83}$ Treaties may expressly distinguish between two types of contracts - investment and commercial. If an investment contract, they receive treaty protection as an investment. Commercial contracts are referenced as an illustration of contractual arrangements that must not fall under the concept of investment (more discussion on this comes in the section on uniform private law conventions and contract interpretation below). Contracts are also occasionally mentioned in substantive treaty provisions, such as umbrella clauses. ${ }^{84}$ Regarding interpretation, analysed treaties offer rules on dispute settlement in relation to inter-state disputes on treaty

82 An approach adopted by India is remarkable in this regard. After having prepared a revised Model BIT in 2015, India terminated all its previous BITs and started to conclude new ones. See, for instance, Alison Ross, 'India's termination of BITs to begin' GAR 22 March 2017 available at <https://globalarbitrationreview.com/article/1138510/indias -termination-of-bits-to-begin > accessed 25 June 2021. Not all states can be found to aggressively insist on the application of their own template, but Model Biтs nevertheless represent a refined picture of what a particular state considers attractive when isolated from negotiations.

83 See, for instance, Article 1 Canada Model в вт (2004); Article 3 of Brazil Model CF IA (2015); Article 1 of the Netherlands Model BIT 2019; Article 1 of Azerbaijan - Serbia BIT (2011); Article 1 of Benin - Canada BIT (2013); Article 1 of Italy-Qatar BIT (2000).

84 For instance, Article 11(1) of Kazakhstan-Austria BIT (2010); Article 11 Tajikistan - Austria BIT (2010). 
interpretation. ${ }^{85}$ Many treaties of the new generations introduce more elaborate provisions on treaty interpretation that include binding interpretation by joint commissions or committees ${ }^{86}$ and clarification of the rules applicable to treaty interpretation. ${ }^{87}$ Some treaties also offer clarifications even for the interpretation of national law exercised by treaty-based tribunals. ${ }^{88}$ No treaty, however, appears to exist as of 30 January 2019 that provides any clarity as to how contracts should be interpreted.

This gap in IIAs and model BITs has a direct connection with the lack of uniformity in approaches to contract interpretation in investment treaty arbitration. One can explain this gap as being rather deliberate and thus indirectly supporting the exclusivity of national law in relation to contract interpretation. One can also interpret the lack of guidance in IIAs as carte blanche for other interpretative techniques that are not necessarily based on national law. To recall, as analysed in Chapter 1, arbitration awards reveal a majority of occasions in which tribunals have applied national law to contract interpretation ( $53 \%$ of cases with elements of contract interpretation), but the predominant number of these awards does not show however that interpretative rules of national law were in fact applied (only 9\% of awards with elements of contract interpretation indicate application of interpretative rules). Furthermore, a rather significant number of cases $(47 \%)$ also demonstrate ascertainment

85 For instance, Article 10 of Chile - Switzerland вiт (1999); Article 8 of China - Colombia BIT (2008).

86 See, for instance, Albania - Israel BIT (1996), Argentina - Israel BIT (1995) and BelgiumLuxembourg Economic Union - China BIT (2005). For an overview of the trend, see Yuliya Chernykh, 'Assessing Convergence between International Investment Law and International Trade Law through Interpretative Commissions/Committees: A Case of Ambivalence?' in Szilárd Gáspár-Szilágy, Daniel Behn and Malcolm Langford (eds), Adjudicating Trade and Investment Law:Convergence orDivergence?(Cambridge University Press 2020) 211-243.

87 Canada - EU CETA (2016) stipulates, for instance, in Article 8.31: 'When rendering its decision, the Tribunal established under this Section shall apply this Agreement as interpreted in accordance with the Vienna Convention on the Law of Treaties, and other rules and principles of international law applicable between the Parties.' See, also Article 24 of Belarus India BIT (2018) and Article 3.13 of EU - Singapore Investment Protection Agreement (2018).

88 For instance, Article 8.31 of the CETA, Article 3.42 of the EU-Vietnam. Article 8.31 of the CETA reads as follows: 'For greater certainty, in determining the consistency of a measure with this Agreement, the Tribunal may consider, as appropriate, the domestic law of a Party as a matter of fact. In doing so, the Tribunal shall follow the prevailing interpretation given to the domestic law by the courts or authorities of that Party and any meaning given to domestic law by the Tribunal shall not be binding upon the courts or the authorities of that Party.' 
of the content of contractual provisions that were not expressly based on national law regulation of contract interpretation. The existent uncertainty around application of national law to contract interpretation in investment treaty arbitration calls for an appropriate clarification in IIAs and Model BITs.

The necessity may become more obvious if one looks at issues through the paradigm of Jeswald Salacuse, who suggested that investment treaty disputes trigger three legal frames - international, national and contractual. ${ }^{89}$ Given that some IIAs have already started to expressly clarify how international and national regulation have to be approached, i.e. methods for treaty and statutory interpretation, the time is ripe to give clarification in relation to contract interpretation as well. The UNCTAD's statement, with its emphasis on the necessity to enhance coordination between various regulations affecting investment, ${ }^{90}$ may be viewed as supporting the proposition too. Overall, with clear treaty guidelines on the precise role of national law in the analysis of investment treaty tribunals more generally and in the analysis relating to contract interpretation in particular, much more clarity and predictability could be achieved.

\subsubsection{Uniform Private Law Conventions}

While IIAs are silent on rules concerning contract interpretation, it is interesting to turn our attention to the harmonisation of private law rules via public international law sources in the field of international commercial law - uniform private law conventions. ${ }^{91}$ These conventions are unduly ignored in the

89 Jeswald W Salacuse, The Three Laws of International Investment: National, Contractual, and International Frameworks for Foreign Capital (Oxford University Press 2013) 35-50.

90 UNCTAD noted, for instance, as follows: 'In sum, in considering next steps for investment policy reform, countries should be guided by the objectives of fostering coherence, maximizing synergies and improving interaction between various instruments that govern investment.' - UNCTAD, World Investment Report 2018: Investment and New Industrial Policies $<$ https://unctad.org/en/PublicationsLibrary/wir2018_en.pdf>accessed 25 June 2021.

91 The term can be found in Jürgen Basedow, 'Uniform Private Law Conventions and the Law of Treaties' (2006) 11(4) Uniform Law Review 731, 731-746 or here - Ulrich G Schroeter, 'The Withdrawal of Reservations under Uniform Private Law Conventions' (2015) 20(1) Uniform Law Review 1, 1-18. The uniform private law conventions may also be referred to as 'international uniform commercial law conventions' - see Herbert Kronke, 'International Uniform Commercial Law Conventions: Advantages, Disadvantages, Criteria for Choice' (2000) 5(1) Uniform Law Review 13, 13-21. These conventions may also be addressed as 'private commercial law conventions' - see Roy Goode, 'Private Commercial Law Conventions and Public and Private International Law: The Radical Approach of the Cape Town Convention 2001 and its Protocols' (2016) 65(3) International and Comparative Law Quarterly 523. 
general discourse relating to international treaties and conventions. ${ }^{92}$ They are also invisible in the discourse of investment treaty arbitration. Because the uniform private law conventions deal primarily with the rights and obligations of non-state parties, they are indeed somewhat peculiar. At the same time they remain international conventions and impose certain obligations on contracting state parties. ${ }^{93}$ The private law dimension [regulatory focus] of these conventions makes it highly probable that they would have certain provisions on contract interpretation. What follows below will accordingly discuss whether uniform private law conventions provide any clarity regarding contract interpretation, and if so, whether these rules may be of any assistance in the context of investment treaty arbitration. The focus here is thus two-fold and encompasses both a question on availability and a question on applicability.

The answer to the question on availability could easily receive a negative response if one looks back at history. At the time of the previously cited scholars and international judges, Hersch Lauterpacht or Lord McNair, for instance, international law was quite far from being able to cover private law matters and from attempting to harmonise national regulation. An insight from a bit further back, in 1907, prior to Hersch Lauterpacht's and Lord McNair's time, reveals the most striking context of the discussion on the interaction between conventional norms and contracts one could ever imagine. Instead of harmonising private law in relation to contracts, 17 countries had to agree to limit the use of force in relation to the recovery of contractual debts 'claimed from the Government of one country by the Government of another country as being due to its nationals. ${ }^{94}$ The resulting Convention respecting the Limitation of

92 This observation is easy to confirm by looking at classical monographs in public international law. The scholars cited above, Jürgen Basedow, Roy Goode and Ulrich G. Schroeter share this view.

93 Most typical for these conventions are to impose certain undertakings on harmonisation and unification of regulation in a specific field upon the contracting parties.

94 Dramatic events in 1902 surrounding the use of military force by the United Kingdom, Germany and Italy to compel Venezuela to comply with contractual debts, preceded the conclusion of the Convention respecting the Limitation of the Employment of Force for the Recovery of Contract Debts on 18 October 1907. From 1909 to 1911, 17 states ratified the convention: Austria-Hungary, Denmark, El Salvador, Germany, Great Britain, Mexico, the Netherlands, Russia, and the USA (all on 27 November 1909), Nicaragua (on 19 November 1910), China (on 15 January 1910), Haiti (on 2 February 1910), France (on 7 October 1910), Norway (on 19 November 1910), Guatemala (on 15 March 1911), Portugal (on 13 April 1911), and Panama (on 11 November 1911). On the contemporaneous perception of the convention, as well as its context and the history of its conclusion, see George Winfield Scott, 'Hague Convention Restricting the Use of Force to Recover on Contract Claims' (1908) 2(1) The American Journal of International Law 78, 78-94. On the modern understanding of the Convention's role, see Wolfgang Benedek, 'Drago-Porter Convention (1907), Max 
the Employment of Force for the Recovery of Contract Debts (1907), or the Drago-Porter Convention, imposed an obligation not to use force before having recourse to arbitration in relation to the question of contractual debts. Later, the UN Charter would outlaw the use of force and the Convention became redundant. As a result, adjudicative bodies, in particular arbitral institution, became the real battlefields. ${ }^{95}$ For the sake of completeness, it should be acknowledged that some initiatives in the field of the harmonisation of intellectual property law, the transport of goods by rail and by sea, as well as in other fields were also ongoing at the beginning of the last century. ${ }^{96}$ The real results covering a broad range of private law regulation appeared only with the intensification of international commercial relations after the Second World War. The enhanced work of the two institutions - the International Institute for the Unification of Private Law (UNIDROIT) as an independent intergovernmental organisation with a mission to modernise, harmonise and coordinate private and commercial law between states ${ }^{97}$ and the UN Commission on International Trade Law (UNCITRAL) on the unification of international trade law ${ }^{98}$ contributed most to elaboration of the substantive harmonised rules in the private law uniform conventions. The work of the Hague Conference on Private International Law $(\mathrm{HCCH})$ contributed mostly to other aspects of harmonisation, relating primarily to the choice of law and jurisdictions. ${ }^{99}$

Planck Encyclopedia of Public International Law <https://opil.ouplaw.com/view/10.1093/ law:epil/978019923169o/law-978o19923169o-e733> updated January 2007, accessed 25 June 2021.

95 According to Taylor St John, permanent arbitral institutions ultimately outlawed the use of force: 'The gradual, decades-long effort toward outlawing the use of force dovetailed with the development of permanent institutions for arbitration' - see Taylor St John, The Rise of Investor-State Arbitration: Politics, Law, and Unintended Consequences (Oxford University Press 2018) 59 .

96 For a broader historical account covering the appearance of uniform private law conventions, see Jürgen Basedow, 'Uniform Private Law Conventions and the Law of Treaties' (2006) 11 (4) Uniform Law Review 731, 731-736.

97 UNIDROIT has existed since 1926 - <www.unidroit.org > accessed 25 June 2021.

98 UNCITRAL has existed since 1966 - <https://uncitral.un.org/en> accessed 25 June 2021.

99 HCCH has existed since 1893. Apart from some conventions with limited reach relating to the choice of law regarding the sale of goods, $\mathrm{HCCH}$ has not elaborated any other convention or treaty that would address any specific type of contract. For a broad overview of the conventions prepared by HCCH, see Dieter Martiny, 'Hague Conventions on Private International Law and on International Civil Procedure', Max Planck Encyclopedia of Public International Law <https://opil.ouplaw.com/view/10.1093/law:epil/978o19923169o/ law-978019923169o-e942 > updated September 2009, accessed 25 June 2021. The significant contributions of HCCH in the development of conflict of laws regulation include the Principles on Choice of Law in International Commercial Contracts. 
These days, the unification and harmonisation of international commercial law results in numerous instruments directly regulating various contracts, ${ }^{100}$ such as the Hague Rules on Bills of Lading (1924), ${ }^{101}$ the Warsaw Convention on Air Carriage (1929), ${ }^{102}$ the Geneva Convention on the Bill of Exchange and Promissory Notes (1930), ${ }^{103}$ the CISG (1980), ${ }^{104}$ the UN Convention on Independent Guarantees and Stand-by Letters of Credit (1995), ${ }^{105}$ the UNIDRoIt Convention on International Financial Leasing (1988), ${ }^{106}$ the Unidroit Convention on International Factoring (1988), ${ }^{107}$ and the Cape Town Convention on International Interests in Mobile Equipment(2001), to name but a few. ${ }^{108}$ There are also some conventions that may come into force and start to uniformly regulate other types of contractual arrangements such as the UNIDROIT Convention on Agency in the International Sales of Goods (1983), for instance. ${ }^{109}$ Furthermore, the UNIDROIT's ongoing work

100 Unification of certain facets of contract law in the EU as a supra-national law and not international law is left aside from this inquiry. For an overview of the EU law see Achilles Skordas and Luke Dimitrios Spieker, 'Supranational Law', Max Planck Encyclopedia of Public International Law <https://opil.ouplaw.com/view/10.1093/law:epil/978019923169o/ law-978019923169o-e1723> last updated May 2014, accessed 25 June 2021.

101 'International Convention for the Unification of Certain Rules of Law relating to Bills of Lading ("Hague Rules"), and Protocol of Signature' <https://comitemaritime.org/wpcontent/uploads/2018/o5/Status-of-the-Ratifications-of-and-Accessions-to-the-BrusselsInternational-Maritime-Law-Conventions.pdf > accessed 25 June 2021.

102 'Contracting Parties to the Convention for the Unification of Certain Rules Relating to International Carriage by Air Signed at Warsaw on 12 October 1929 and the Protocol Modifying the Said Convention Signed at the Hague of 28 September 1955'<www.icao. int/secretariat/legal/List\%20of\%2oParties/WC-HP_EN.pdf> accessed 25 June 2021.

103 United Nations, 'Convention providing a Uniform Law for Bills of Exchange and Promissory Notes' <https://treaties.un.org/pages/LONViewDetails.aspx?src=LON\&id= $553 \&$ chapter $=30 \&$ clang=_en $>$ accessed 26 September 2021.

104 UNCITRAL, 'Status: United Nations Convention on Contracts for the International Sale of Goods' <https://uncitral.un.org/en/texts/salegoods/conventions/sale_of_goods/cisg/sta tus> accessed 25 June 2021.

105 UNCITRAL, 'Status United Nations Convention on Independent Guarantees and Stand-by Letters of Credit' <https://uncitral.un.org/en/texts/payments/conventions/independent_ guarantees/status> accessed 25 June 2021.

106 UNIDROIT, 'Status - UNIDROIT Convention on International Financial Leasing' <https:// www.unidroit.org/instruments/leasing/convention/status/> accessed 26 September 2021.

107 UNidroit, 'Status - UNIDROIT Convention on International Factoring' <https://www. unidroit.org/instruments/factoring/status/> accessed 26 September 2021.

108 Unidroit, 'Convention on International Interests in Mobile Equipment (Cape Town, 2001) - Status' <https://www.unidroit.org/instruments/security-interests/cape-town-con vention/> accessed 26 September 2021.

109 Unidroit, 'Status of The Convention on Agency in the International Sale of Goods' $<$ https://www.unidroit.org/instruments/agency/status/> accessed 26 September 2021. 
in relation to contracts of reinsurance ${ }^{110}$ and agricultural land investment contracts, ${ }^{111}$ while being currently within a modest ambition of creating guidance and principles, is not prohibited from turning into more powerful forms of international treaties and conventions. The UNCITRAL in turn also addresses, with its current efforts, contractual aspects of cloud computing in electronic commerce, ${ }^{112}$ the private financing of infrastructure projects ${ }^{113}$ and the judicial sale of ships, ${ }^{114}$ each area inevitably dealing with specific types of contracts.

Of the identified range of conventions currently in force, the CISG appears not only to be among the most powerful, but surprisingly it is the only one directly and explicitly regulating contract interpretation. As evidenced by Annex IX, other mentioned conventions touch contract interpretation only on a tangent through provisions that may impact understanding, but that do not provide universal general regulation/guidance on their interpretation. The CISG was quite close to adhere to their way, were it not for a proposition by Poland that was shared by other delegates, developing further and which was subsequently defended during the UNCITRAL working sessions.

During the 1oth Commission Session, a delegate from Poland specified:

7. It seems advisable to precede article 13 of the draft by a general clause to the effect that in the interpretation and application of the stipulations of a contract, the intention of the parties as well as the purpose they wish to achieve are to be taken into account.

8. The rationale of the foregoing suggestion is as follows:

The draft convention deals with a contract of sale of goods. In case of a dispute, the stipulations of the contract concerned are to be examined. If any of the said stipulations gives rise to doubts, the court when considering a case should try to clear up the intention of the parties at the conclusion of the contract. The court should also

\footnotetext{
110 Unidroit, 'Study L - Formulation of Principles of Reinsurance Contracts Law < https:// www.unidroit.org/work-in-progress/reinsurance-contracts> accessed 25 June 2021.

111 Unidroit, 'Study LXXX B - Preparation of an International Guidance Document on Agricultural Land Investment Contracts' <https://www.unidroit.org/work-in-progress/ agricultural-land-investment> accessed 25 June 2021.

112 UNCITRAL, 'Working Group IV: Electronic Commerce' <https://uncitral.un.org/en/wor king_groups/4/electronic_commerce $>$ accessed 25 June 2021.

113 UNCitraL, 'Privately Financed Infrastructure Projects' <https://uncitral.un.org/en/wor king_groups/1/pfip > accessed 25 June 2021.

114 UNCITRAL, 'Working Group VI: Judicial Sale of Ships' <https://uncitral.un.org/en/wor king_groups/6/sale_ships $>$ accessed 25 June 2021.
} 
consider what the parties wanted to achieve, i.e. what was the purpose of the contract. ${ }^{115}$

Not all delegates were positive about having a general provision on interpretation and the appearance of Article 7 in the semi-final draft of 1978 (ultimately Article 8) did not prevent hot discussions. Criticism ranged from the overall utility and appropriateness of having specific interpretative provisions in the first place, to attacking their precise content. ${ }^{116}$ Article 7 of the CISG was very close to being dropped, in a similar way to provisions on the validity of the contract, the rights of third parties and passing of title to national law that were ultimately excluded from the scope of the CISG regulation. Among the most critical of the provision was the ICC, which suggested that article 7 should have been deleted and if interpretative rules were to be included at all 'a more objective standard should be set up'.117 Later, the representative from Sweden also argued against the introduction of the provision in the text, mainly because it differed from the principles of treaty interpretation contained in Part III of the VCLT. ${ }^{118}$ This opposition was met with resistance and the representatives of many states argued in favour of the provision. Remarkably, the representatives from the USA and the United Kingdom, whose rules are nowadays largely viewed as being different to what the CISG offers for contract interpretation, supported the insertion of Article $7 \cdot{ }^{119} \mathrm{~A}$ view expressed by a delegate from the German

115 UNCITRAL, 'Comments by Governments and international organizations on the draft convention on the international sale of goods (A/CN.9/125 and A/CN.9/125/ Add.l to 3)' (22 March 1977) <https://undocs.org/en/A/CN.9/125/Add.1>, <https://undocs.org/en/A/ CN.9/125/Add.2 >, <https://undocs.org/en/A/CN.9/125/Add.3> accessed 26 September 2021.

116 See, for instance, Gyula Eörsi, 'General Provisions' in Nina M Galston and Hans Smit (eds), International Sales: The United Nations Convention on Contracts for the International Sale of Goods (Matthew Bender 1984), available at <https://iicl.law.pace.edu/cisg/scholarlywritings/general-provisions $>$ accessed 26 September 2021.

117 Ibid.

118 The summary of records describes the position of the representative of Sweden, $\mathrm{Mr}$ Hjerner, in the following words: 'Introducing his delegation's amendment (A/CONF.97/C.1/ L.52), [the representative of Sweden] said that the discussion had shown that there were wide differences of view on the question dealt with in the article. In his opinion, it was neither necessary nor useful to set forth new rules for the interpretation of contracts, which might be contrary to those established in section 3 of the Vienna Convention on the Law of Treaties. That was why his delegation had proposed that article 7 [later Article 8] should simply be deleted.' - see Summary Records of Meetings of the First Committee 6th meeting of 14 March 1980, para. 46. available at <https:/uncitral.un.org/sites/uncitral.un.org/files/media-documents/uncitral/en/a-conf-97-19-ocred-eng.pdf>, accessed 26 September 2021.

119 Analysis of Comments and Proposals by Governments and International Organizations on the Draft Convention on Contracts for the International Sale of Goods, and on Draft 
Democratic Republic reflected a broader compromise that Article 7 [later Article 8] was based on. ${ }^{120}$ Article 8 was adopted unanimously by 42 votes to none, with four abstentions. ${ }^{121}$

During the drafting process, the 1978 version of Article 7 remained almost unchanged compared to what is now Article 8. The minor change related to the specification that a standard of a reasonable person received: a reference to 'of the same as the other party' was included to identify what kind a reasonable person should be. Article 8 in its final wording, that is currently in use, looks as follows:

(1) For the purposes of this Convention statements made by and other conduct of a party are to be interpreted according to his intent where the other party knew or could not have been unaware what that intent was.

(2) If the preceding paragraph is not applicable, statements made by and other conduct of a party are to be interpreted according to the understanding that a reasonable person of the same kind as the other party would have had in the same circumstances.

(3) In determining the intent of a party or the understanding a reasonable person would have had, due consideration is to be given to all relevant circumstances of the case including the negotiations, any practices which the parties have established between themselves, usages and any subsequent conduct of the parties.

Provisions Concerning Implementation, Reservations and Other Final Clauses Prepared by the Secretary-General Document A/Conf.97/9 of 21 February 1980, available at $<$ https://digitallibrary.un.org/record/10782?ln=es> accessed 26 September 2021.

120 Summary Records of Meetings of the First Committee 6th meeting of 14 March 1980 evidences a rather intense discussion of Article 7. The position of the representative of the German Democratic Republic, Mr Wagner, was described in the following words: ' 50 . Mr. WAGNER (German Democratic Republic) said that the existing text of article 7 [later Article 8] did not give rise to major differences of views on the interpretation of contracts. It was a balanced compromise and deserved to be retained ... 54. Mr. HERBER (Federal Republic of Germany) said that the deletion of article 7 [later CISG article 8] would leave a gap in the Convention which would have to be filled by reference to national law. His delegation was thus strongly opposed to its deletion:- see Summary Records of Meetings of the First Committee 6th meeting of 14 March 1980, para. 5o, 54, available at <https://uncitral. un.org/sites/uncitral.un.org/files/media-documents/uncitral/en/a-conf-97-19-ocred-eng. pdf $>$, accessed 26 September 2021.

121 UNCITRAL Official Records 1o March-11 - April 1980, Part Two Summary Records, 6th plenary meeting, p.203, para. 64 - available at <https://uncitral.un.org/sites/uncitral.un.org/files/ media-documents/uncitral/en/a-conf-97-19-ocred-eng.pdf>, accessed 26 September 2021. 
The compromise came at a cost. The content of Article 8 continues to raise numerous concerns of a more nuanced nature. ${ }^{122}$ One can see both strength and weakness in the existing lack of clarity regarding the application of the provision. Its strength lies in the flexibility or even the elasticity of the interpretative method that enables one to see the provision as being compliant even with those systems that at first glance offer a somewhat divergent regime. ${ }^{123}$ Its weakness lies in the ambiguity that opens a door for a 'home bias approach' that, instead of uniform regulation, relies on domestic rules for contract interpretation, even though the CISG attempts to set a preclusive effect on national rules for contract interpretation.

A thorough analysis of Article 8 indeed reveals areas of potential ambiguity. The first striking element lies in the object of interpretation. The text of the provision technically refers to unilateral statements and conduct of a party as an object of interpretation. The UNCITRAL Secretary was careful to make the point clear in the commentary to the first draft of the convention of 1978 emphasising that, 'analytically', the contract is perceived as an exchange of an offer and its acceptance; therefore, principles for interpretation of the components are equally applicable to the interpretation of the whole contract. ${ }^{124}$ The question, however, may arise as to how precisely to deal with these components,

122 For an updated most recent extensive commentary on the provision addressing various areas of critics, see Ingeborg Schwenzer (ed), Schlechtriem\&Schwenzer Commentary on the UN Convention on the International Sale of Goods (CISG) (4th edn, Oxford University Press 2016) 143-180.

123 Jacob S. Ziegel and Professor Claude Samson demonstrate general compliance of the provision with a common law approach, though they note some caveats, relating, for instance, to a more restrictive approach to extrinsic evidence under common law - see Jacob S Ziegel and Claude Samson, 'Report to the Uniform Law Conference of Canada on Convention on Contracts for the International Sale of Goods', July 1981, available at < https://iicl.law.pace.edu/ cisg/bibliography/report-uniform-law-conference-canada-convention-contracts-internatio nal-sale-1>, accessed 26 September 2021; on deeper similarities with common law system on the example of the law of Singapore, see Chan Leng Sun, 'Interpreting an International Sale Contract', presented in 'Celebrating Success: 25 Years United Nations Convention on Contracts for the International Sale of Goods' (Collection of Papers at UNCITRAL - SIAC Conference 22-23 September 2005, Singapore), reproduced with permission of the SIAC at <https://www.cisg.law.pace.edu/cisg/biblio/sunı.html>, accessed 26 September 2021.

124 The Commentary of the UnCitral Secretariat to Article 7 of the Draft 1978 [later CISG Article 8] clarified: 'Nevertheless article 7 is equally applicable to the interpretation of 'the contract' when the contract is embodied in a single document. Analytically, this Convention treats such an integrated contract as the manifestation of an offer and an acceptance. Therefore, for the purpose of determining whether a contract has been concluded as well as for the purpose of interpreting the contract, the contract is considered to be the product of two unilateral acts.' - available at <http://www.cisg-online.ch/index.cfm?pageID=644> accessed 26 September 2021. 
and more particularly whether Article 8 (1) is equally applicable to those contracts, which do not come in refined and distinguishable forms of offers and acceptance (which are arguably a predominant part of contracts). Whether these contracts are to be interpreted through distinguishing common intent, or Article 8(2) with the standard of a reasonable person should guide interpretation remains unsettled. ${ }^{125}$ Furthermore, giving effect to all relevant circumstances of the case, including negotiations, practices established between the parties, usage and their subsequent conduct in Article 8(3), the CISG does not allocate any superior role to any of these elements. This rather deliberate failure makes the operation of the provision less clear and predictable, but again, it also makes it more flexible. Among other common areas of concern are the interaction of Article 8 with plain meaning rules in certain jurisdictions and entire agreement contract clauses, as well as the overall effect of the provision on domestic procedural rules, including parol evidence. ${ }^{126}$

The inherent ambiguity of the provision, ${ }^{127}$ as a result of a compromise in its drafting history and an attempt to meet rather diverse national expectations,

125 Enderlein's and Maskow's Commentary explains the complexity in the following terms: '[2.3] Article 8 relates directly only to the acts (legal acts - referred to below also as acts) of a party and contains no provision for the interpretation of contracts. Insofar as contracts are based on corresponding unilateral acts by the parties, there will be no problems. This also holds true where a party accepts the contract offer made by the other party, for instance, by signing it. When the contract, however, is contained in a joint document of the parties, it cannot be generally determined which party made a specific statement becoming part of the document. Basically, each party has then made a statement relating to the entire, substance of the contract document so that the general rule can be applied, as in the case of corresponding individual statements of intent, i.e. the relevant clause is interpreted first as the statement of the one party and then as the statement of the second party (so already in the Secretariat's Commentary, O.R., 18; Farnsworth/BB, 101), their identity resulting in a common intent. Honnold (137) wants to apply here only paragraph 3 , which seems inconsistent to us.' - see Fritz Enderlein and Dietrich Maskow, International Sales Law: United Nations Convention on Contracts for the International Sale of Goods, Convention on the Limitation Period in the International Sale of Goods (Oceana Publications 1992) available at $<$ https://iicl.law.pace. edu/sites/default/files/cisg_files/enderlein.html\#arto8> accessed 26 September 2021.

126 On the complexity surrounding the parol evidence rule and the CISG, see, for instance, Bruno Zeller, 'The Parol Evidence Rule and the CISG: a Comparative Analysis' (2003) 36 (3) Comparative and International Law Journal of Southern Africa, 308-324; see also parts IV (4) and viII to the commentary to Article 8 in Ingeborg Schwenzer (ed), Schlechtriem\&Schwenzer Commentary on the UN Convention on the International Sale of Goods (CISG) (4th edn, Oxford University Press 2016) 158-161, 179-180.

127 For an extensive discussion on the consequences and possible responses to the ambiguity of Article 8, see Donald J Smythe, 'Reasonable Standards for Contract Interpretation Under the CISG' (2016) 25 Cardozo Journal of International and Comparative Law 1. While the ambiguity of Article 8 of the CISG is generally perceived to be a problem, some choose to praise it for its practicality and universality - see Gyula Eörsi, 'General Provisions' in 
does not put it aside. Article 8 is frequently used by domestic courts and international commercial arbitration tribunals. ${ }^{128}$ To enhance its further uniform application, the CISG Advisory Council ${ }^{129}$ issued an opinion ${ }^{130}$ clarifying its various facets and reconfirming that interpretative provisions of the CISG prevail over domestic regulation. The opinion emphasised the default nature of the provision and the parties' right to modify its content in relation to principles applicable to contract interpretation. The opinion made it also clear that Article 8 does not encapsulate the plain meaning rule per se, nor does it encapsulate the parol evidence rule. Existing commentaries to the CISG may offer some nuanced views on the operation of Article 8, but they essentially conform to what the CISG Advisory Council clarified.

Turning from the issue of availability in international law to the issue of applicability in investment treaty arbitration, one has to consider the original scope of application of CISG, and possiblerelevance of the sales of goods for investment treaty disputes. The CISG is applicable on two occasions: firstly when a contract pertaining to the sale of goods is concluded between parties whose places of business are in different states and when those states are contracting states to the CISG (Article 1(1)(a)) and secondly when a contract pertaining to the sale of goods is concluded between parties whose places of business are in different states and the rules of private international law lead to the application of the law of the contracting state (Article $1(1)(b))$. Either ground may arise in relation to the sale of goods that come in focus in investment treaty arbitration.

Nina M Galston and Hans Smit (eds), International Sales: The United Nations Convention on Contracts for the International Sale of Goods, (Matthew Bender 1984), 2-1 to 2-36, available at <https://iicl.law.pace.edu/cisg/scholarly-writings/general-provisions $>$, accessed 26 September 2021.

128 Albert H Kritzer CISG Database maintained by the Pace Law School contains 423 retrieved cases - see <https://iicl.law.pace.edu/cisg/cisg> accessed 26 September 2021; Case Law on UnCitral Texts (CLOUT) contains at least 485 cases - see $<$ https://uncit ral.un.org/en/case_law>, accessed 25 June 2021; see also the UNCITRAL CISG Digest 2016 edition - <http://www.uncitral.org/pdf/english/clout/CISG_Digest_2016.pdf $>$, accessed 25 June 2021.

129 The CISG-Advisory Council of (CISG-AC) is a private initiative supported by the Institute of International Commercial Law at Pace University School of Law and the Centre for Commercial Law Studies, Queen Mary, and University of London. The International Sales Convention Advisory Council (CISG-AC) has a mission to enhance understanding of the CISG and to promote its uniform application.

130 Richard Hyland 'CISG-AC Opinion no 3: Parol Evidence Rule, Plain Meaning Rule, Contractual Merger Clause and the CISG, 23 October 2004 Rapporteur: Professor Richard Hyland, Rutgers Law School, Camden, NJ, USA' < https://www.trans-lex.org/500153/_/cisgadvisory-council-opinion-no-3:-parol-evidence-rule-plain-meaning-rule-contractualmerger-clause-and- > accessed 26 September 2021. 
Furthermore, it is difficult to find reasons why the CISG should not be given effect in contexts that do not relate to contractual disputes when some of these conditions are satisfied. Obviously, its effect comes not from outside but rather from within the contract in question, but that itself changes nothing.

What makes the CISG, and any other interpretative rules, possibly less relevant, is the specific nature of questions that usually arise in relation to contracts of international sales of goods in investment treaty arbitration. The nature of questions that arise in relation to the international sales of goods is rather of identity, or qualification, than of interpretation. ${ }^{131}$ In the context of investment treaty arbitration, contracts of sale are frequently associated with commercial contracts and thus often contrasted with investment contracts. The discussion, accordingly, limits the investigation to just one question about whether a particular contract is a contract of sale and thus deprived of treaty protection or not. Typically, if at all, this sort of investigation takes place at the jurisdictional stage. It may also be part of the discussion at the merits stage, most often though when the jurisdictional stage is connected to the merits. For this task, IIAs and not national laws primarily guide tribunals in their qualification as to whether a particular contract is a commercial contract or a sales contract and not an investment contract. At the same time, it is not automatic, however, for qualifications to exclude interpretation. While IIAs form independent concepts of what investment and commercial contracts are, the precise content of these contracts, whenever needed, should be established, according to the proper law of the contract, of which the CISG (being a uniform private law convention) may be part. A thorough understanding of the parties' mutual obligations might indeed be needed to decide to which type a contract belongs either to investment or commercial ones. Certain provisions may require more thorough ascertainment than what is on the surface. On some occasions, while still presenting a minimalistic analysis of qualifications, tribunals expressly acknowledge that a contract has an interpretative element in itself. ${ }^{132}$ On other occasions, tribunals acknowledge that qualifications necessitate a rather thorough study of the parties' undertakings, taken as a broad picture of all transactions involved. ${ }^{133}$ Furthermore, contracts of sale may appear in other contexts

131 A typical kind of qualification analysis is helpfully captured in Joy Mining Machinery Limited and The Arab Republic of Egypt, ICSID Case No. ARB/o3/11, Award on Jurisdiction dated 6 August 2004, para. 55 .

132 See, for instance, Global Trading Resource Corp. and Globex International, Inc. v. Ukraine, ICSID Case No. ARB/o9/11, Award dated 1 December 2010, para. 57.

133 See, for instance, H\&H Enterprises Investments, Inc. and Arab Republic of Egypt, ICSID Case No. ARB/o9/15, The Tribunal's Decision on Respondent's Objections to Jurisdiction dated 5 June 2012, para. 42. 
of investment treaty arbitration that might necessitate a thorough analysis and possible interpretation. Issues of foreseeability for the calculation of compensation might open room for an interpretative exercise. ${ }^{134}$ Be that as it may, the CISG has not received any application in the analysis of sales agreements in investment treaty arbitration in the awards analysed in this book, nor has it received any broader impact (extended by analogy or convenience) for interpreting other types of contractual arrangement.

Remarkable in this silence, is the appraisal that the CISG received as the convention in one case brought under the UK - Egypt BIт Joy Mining Machinery Limited and The Arab Republic of Egypt (ICSID Case No. ARB/o3/11), but again without being put into operation. In this case, the tribunal recognised the CISG's role in unifying the laws governing sales contracts, but emphasised that sales and procurement contracts involving state agencies would not typically qualify as investment in the absence of specific investment-related undertakings:

58. The Tribunal is also mindful that if a distinction is not drawn between ordinary sales contracts, even if complex, and an investment, the result would be that any sales or procurement contract involving a State agency would qualify as an investment. International contracts are today a central feature of international trade and have stimulated far reaching developments in the governing law, among them the United Nations Convention on Contracts for the International Sale of Goods, and significant conceptual contributions. Yet, those contracts are not investment contracts, except in exceptional circumstances, and are to be kept separate and distinct for the sake of a stable legal order. Otherwise, what difference would there be with the many State contracts that are submitted every day to international arbitration in connection with contractual performance, at such bodies as the International Chamber of Commerce and the London Court of International Arbitration? ${ }^{135}$ [emphasis added]

While Article 8 of the CISG has not informed any of the interpretative efforts of the treaty-based tribunals in the analysed cases, its overall conceptual framework turned out to be a point of inspiration for some scholars in proposing a solution for a contract-treaty divide in investment treaty arbitration. The CISG,

134 See, for instance, the dissenting opinion of Zachary Douglas in Koch Minerals Sàrl and Koch Nitrogen International Sàrl v. Bolivarian Republic of Venezuela, ICsid Case No. ARB / 11/19, para. 13 .

135 Joy Mining Machinery Limited and The Arab Republic of Egypt, ICSID Case No. ARB/o3/11, Award on Jurisdiction dated 6 August 2004. 
on the one hand, represents a uniform regulation for the international sale of goods, and on the other hand, a unique mechanism that retains a certain autonomy of the parties to a contract to modify its provisions and to opt out from it entirely. Julian Arato used both of these features in his proposition to deal with investment contracts. On the one hand, a multilateral convention on international investment contracts could turn into a uniform regulation of investment contracts with a harmonised set of standards of investment protection, while on the other hand, foreign states and investors could retain a certain autonomy to modify the provisions in their contracts or to opt out of them entirely. ${ }^{136}$

There is nothing unusual in such proposition. Similar attempts to rely on a successful multilateral instrument can be found in other contexts. For instance, the New York Convention on the Recognition and Enforcement of Foreign Arbitral Awards served as a point of inspiration for introduction of a legal fiction that equates the decisions of a future (currently non-existent) investment court with awards for the purpose of their enforcement in the new generation of free trade agreements. ${ }^{137}$

The question that can be raised in relation to a proposal to rely on the CISG model for a multilateral instrument for investment contracts, lies not only in the overall feasibility of the multilateral proposal, but also in the much harder necessity to come to a common understanding of the interplay between contracts and treaties. Should that happen, it would be interesting to see whether interpretative provisions of the CISG, or the VCLT, or other sources, would be part of the proposal.

To conclude this part of the discussion on the relevance of the uniform private law conventions for contract interpretation in investment treaty arbitration, one has to respond to questions of availability and applicability. In terms of availability, Article 8 contains interpretative provisions that govern the interpretation of the international sale of goods. While some discussion may touch on its efficiency, the provision nevertheless represents an exhaustive framework for analysis in relation to all inquiries directed at the interpretation

136 Julian Arato, 'The Logic of Contract in the World of Investment Treaties', (2016) 58 William \& Mary Law Review 351, 364-365.

137 The wording equating final awards rendered under the investment sections of free trade agreements to arbitral awards in claims arising out of a commercial relationship or transaction is contained in the EU-Vietnam FTA, the TTIP and the CETA. See also August Reinisch, 'Will the EU's Proposal Concerning an Investment Court System for CETA and TTIP Lead to Enforceable Awards? - The Limits of Modifying the ICSID Convention and the Nature of Investment Arbitration' (2016) 19 (4) Journal of International Economic Law $761,761-786$. 
of contracts and is widely used in a commercial context. And while the CISG is frequently applicable via private international law rules as a proper law of a contract and not as a source of public international law per se, as a matter of principle, there is no reason not to consider it for the purpose of interpretation of contracts that fall into its scope of application. Given that contracts for the international sale of goods may appear in the context of investment treaty arbitration, and their analysis may be more complex than simply identity/ qualification, no grounds exist to ignore the CISG when it constitutes a part of the law applicable to these contracts.

To sum up, the distinctions between contracts and international law as objects of interpretation are so considerable that the mere question of relevance of interpretative rules of international law to contract interpretation may sound like an absurd question to which a serious answer is attempted to be offered in this chapter. The common origin of interpretative rules of international law and domestic interpretative rules, as well as the frequent occasions when state or state-related entities become contracting parties allows the question on the extension of interpretative rules of international law to contract interpretation to be less absurd, whereas a reliance on the rules of treaty interpretation at least in one investment case [hybrid, precise qualification] makes the question less hypothetical.

As approaches in national laws differ in relation to contract interpretation, so too may they differ in international law in respect to treaty interpretation in certain subfields of international law and in relation to interpretation regarding different objects of interpretation being treaties, jurisdictional instruments, unilateral acts, customs, etc. The interpretative rules do not operate in a vacuum and are supplemented by the relevant legal framework: for international law by the relevant provisions of international law and for contract by the relevant provisions of national laws (background law). Crossing different legal orders (national law - international law), certain interpretative rules or canons of interpretation can potentially retain legacy and even supplant some gaps. However, similar interpretation-related concepts and approaches on domestic and international levels, more often than not, have peculiar operation and may mislead as to their capacity to operate interchangeably.

\subsection{Customary International Law}

To answer the question as to whether customary international law contains any rules for the interpretation of contracts, one may attempt to look at customary international law in its entirety. This task would be extremely difficult, as well 
as considerably more cumbersome than the analysis of IIAs performed previously. The complexity of identifying the rules of customary international law will become a major challenge. ${ }^{138} \mathrm{~A}$ more pragmatic and yet still meaningful approach to answer the question is to only examine those rules of customary international law that matter in the context of investment treaty arbitration.

Customary international law becomes applicable or relevant to investment treaty arbitration in various ways. State attribution serves as one of the most typical examples where rules of customary international law are frequently applied. ${ }^{139}$ State succession forms another, though less frequent, example. ${ }^{140}$ Furthermore and as discussed, whenever treaty-based tribunals rely on rules on treaty interpretation as codified by the VCLT, they may be viewed as giving effect to customary international law. Finally, rules of customary international law that protect the property of aliens retain their relevancy for state contracts in investment treaty arbitration. Even if they do not necessarily constitute independent grounds for a claim, ${ }^{141}$ these rules may become indispensable for

138 Only a fraction of customary international law rules are formally expressed in treaties. The ongoing work of the International Law Commission on the identification of customary international law evidences this complexity - see Text of the Draft Conclusions as Adopted by the Drafting Committee on Second Reading 'Identification of Customary international Law' A/CN.4/L.908, available at <http://legal.un.org/docs/?symbol=A/ CN.4/L.908> accessed 25 June 2021.

139 International Law Commission, 'Draft Articles on Responsibility of States for Internationally Wrongful Acts, with commentaries 20o1' available at <http://legal. un.org/ilc/texts/instruments/english/commentaries/9_6_20o1.pdf>, accessed 25 June 2021. The customary nature of attribution rules have been widely recognised - see Kaj Hobér, 'State Responsibility and Attribution' in Peter Muchlinski and others (eds), The Oxford Handbook of International Investment Law (Oxford University Press 2008) 551; Simon Olleson, 'Attribution in Investment Treaty Arbitration', (2016) 31(2) ICSID Review - Foreign Investment Law Journal 457; Zachary Douglas, 'Specific Regimes of Responsibility: Investment Treaty Arbitration' in James Crawford and others (eds), The Law of International Responsibility (Oxford University Press 2010) 815, 821.

140 In the 41 years since its adoption, the 1978 Vienna Convention on Succession of States in respect of Treaties has secured only 23 parties, having been unable to achieve a broader acceptance among states and therefore fragmenting the regulatory field of state succession - see <https://treaties.un.org/Pages/ViewDetails.aspx?src=IND\&mtdsg_no=XXIII$2 \&$ chapter=23\&clang=_en $>$, accessed 26 September 2021; for an overview of the relevance of the rules of state succession to investment treaties, the role of customary international law and the limited number of cases where the issue was addressed, see Christian J Tams, 'State Succession to Investment Treaties: Mapping the Issues' (2016) 31 (2) ICsID Review Foreign Investment Law Journal 314, 314-343.

141 Kate Parlett, for instance, provides a detailed observation on the possibilities and jurisdictional constraints for self-standing customary international law claims in investment treaty arbitration- see Kate Parlett, 'Claims under Customary International Law in ICSID Arbitration' (2016) 31 (2) ICSID Review - Foreign Investment Law Journal 434-456. See also, 
assessing the content of treaty standards of investment protection in investment treaty arbitration. Some IIAs incorporate a minimum standard of treatment under customary international law into their standards of investment protection; ${ }^{142}$ others while not expressly incorporating a minimum standard of treatment may nevertheless treat the rule as a benchmark for construing the content of a treaty standard in a relevant IIA. ${ }^{143}$

Of the described occasions when customary international law becomes applicable or relevant for investment treaty arbitration, only the minimum standard rule cannot easily be discarded from the analysis from the outset

Berk Demirkol, 'Non-treaty Claims in Investment Treaty Arbitration' (2018) 31 Leiden Journal of International Law 59, 59-91.

142 For instance, Article 5 of the 2012 USA Model BIT expressly equates FET and full protection and security standards to a minimum standard of treatment as understood under customary international law - the 2012 USA Model BIT is available at $<\mathrm{https} / / / 2009-2017$. state.gov/documents/organization/188371.pdf>, accessed 25 June 2021. It is also wellknown that Article 1105 of the NAFTA entitles parties to a 'minimum standard of treatment' - see Notes of Interpretation of Certain Chapter Eleven Provisions (NAFTA Free Trade Commission, 31 July 2001), available at $<$ http://www.sice.oas.org/tpd/nafta/Com mission/CH1understanding_e.asp >, accessed 25 June 2021. Jean Ho characterises the interaction between international investment law and customary international law, when FET expressly relies on a minimum standard of treatment (MST), as 'MST-linked FET' - see Jean Ho, State Responsibility for Breaches of Investment Contracts (Cambridge University Press 2018) 229-237. See also OECD (2004), 'Fair and Equitable Treatment Standard in International Investment Law', OECD Working Papers on International Investment, 2004/o3, OECD Publishing, <https://www.oecd.org/daf/inv/investment-policy/WP-2004_ 3.pdf>, accessed 25 June 2021; Martins Paparinskis, The International Minimum Standard and Fair and Equitable Treatment (Oxford University Press 2013) 14-98.

143 A view may be traced back to the Abs-Shawcross Draft Convention and the oEcD Draft Convention on the Protection of Foreign Property where drafters gave a definition of FET via the minimum standard of treatment under customary international law - Hermann Abs and Hartley Shawcross, 'The Proposed Convention to Protect Foreign Investment: A Round Table', (1960) 9 Journal of Public Law 115, 119-120; oEcD, 'The Draft Convention on the Protection of Foreign Property' (OECD Publication 1962) $9<$ www.oecd.org/ investment/internationalinvestmentagreements/39286571.pdf> accessed on 25 June 2021; Yuliya Chernykh, 'The Gust of Wind: The Unknown Role of Sir Elihu Lauterpacht in the Drafting of the Abs-Shawcross Draft Convention' in Stephan W Schill and others (eds), International Investment Law and History (Edward Elgar Publishing 2018) 254. See also Campbell McLachlan, 'Is There an Evolving Customary International Law on Investment?' (2016) 31(2) ICSID Review - Foreign Investment Law Journal 257, 257, 266; for an earlier, similar opinion of the same author on the role of customary international law for international investment law, see Campbell McLachlan, 'Investment Treaties and General International Law' (2008) 57(2) International and Comparative Law Quarterly $361,361-401$. 
and requires a deeper assessment. Indeed, the latter category directly interacts with contracts, whereas other types of described rules of customary international law do not have a similar exposure. Clearly stating that it is inappropriate to automatically equate a breach of contract to a breach of international law and acknowledging that an entry into or a breach of a contract by a state organ may be attributable to the state, ${ }^{144}$ at no point do the ILC Articles on the Responsibility of States for Internationally Wrongful Acts clarify how those contracts have to be ascertained. Furthermore, an occasion of reliance on the content of contractual provisions in this work for deciding on state attribution does not reveal any specific rule of customary international law for ascertaining their content. ${ }^{145}$ Rules on state succession to investment treaties have nothing to do with contracts in principle. As discussed, the rules for treaty interpretation do not turn into a functional substitute for the rules for contract interpretation. The only hypothesis to be assessed thus falls on those rules of customary international law that actively interact with state contracts by offering them international protection.

A closer analysis of the operation of the rules of customary international law in relation to state contracts will reveal an absence of rules for ascertaining their content and the reason for this absence. Customary international law offers protection primarily for those breaches of state contracts that are committed by states in their sovereign capacity. The expropriation of contractual rights, interference with contractual rights in an arbitrary manner contrary to a minimum standard of treatment and the denial of justice are three situations that are traditionally perceived as violating customary international law. ${ }^{146}$

144 A commentary to Article 4 the ILC Articles explains: 'It is irrelevant for the purposes of attribution that the conduct of a State organ may be classified as "commercial" or as acta iure gestionis. Of course, the breach by a State of a contract does not as such entail a breach of international law. Something further is required before international law becomes relevant, such as a denial of justice by the courts of the State in proceedings brought by the other contracting party. But the entry into or breach of a contract by a State organ is nonetheless an act of the State for the purposes of article 4, and it might in certain circumstances amount to an internationally wrongful act.' - International Law Commission, 'Report of the International Law Commission on the Work of its Fifty-third Session' (23 April-1 June and 2 July-10 August 2001) A/CN.4/SER.A/2001/Add.1 (Part 2), 41 <https://legal.un.org/ilc/ publications/yearbooks/english/ilc_20o1_v2_p2.pdf>> accessed 26 September 2021.

145 Garanti Koza LLPv. Turkmenistan, ICSID Case No. ARB/11/20; Award of 19 December 2016, para. 335 .

146 Stephan W Schill, 'The Impact of International Investment Law on Public Contracts' in Mathias Audit and Stephan WSchill (eds), Transnational Law of Public Contracts (Bruylant 2016) 236-238; Régis Bismuth, 'Customary Principles Regarding Public Contracts Concluded with Foreigners' in Mathias Audit and Stephan W Schill (eds), Transnational Law of Public Contracts (Bruylant 2016) 334-336. 
States may commit these violations either by sovereign decisions, directly and intentionally modifying or terminating state contracts, or by sovereign decisions modifying the legal environment of state contracts, as well as by other sovereign decisions adversely affecting contractual rights. ${ }^{147}$ Having looked at this broad scope of protection, one may still expect customary international law in its engagement with contracts to offer certain rules for their ascertainment. The obvious negative answer appears only when one appreciates the precise approach that customary international law takes in relation to state contracts when providing them international protection. Rather than being treated as contracts, state contracts are treated as property under customary international law. Protection is offered only to those state contracts that have proprietary features and for those violations of international law that interfere with the proprietary, contract-related rights of a foreign investor. Instead of looking at contracts as contracts, customary international law accordingly looks at contracts as property. ${ }^{148}$ This assimilation not only explains the restricted protection offered to state contracts under customary international

147 Régis Bismuth, 'Customary Principles Regarding Public Contracts Concluded with Foreigners' in Mathias Audit and Stephan W Schill (eds), Transnational Law of Public Contracts (Bruylant 2016) 334-336.

148 There is nothing unusual in this assimilation if one looks at precedents on contract as property in national laws as valuably summarised by Jean Ho through the overview of the expanded meaning of property, constitutional protection of property rights and judicial elaboration on contract as property - Jean Ho, State Responsibility for Breaches of Investment Contracts (Cambridge University Press 2018) 142-152. Furthermore, a comparative perspective on contracts as property, in the field of human rights and in investment treaty arbitration, reveals that this approach is not exclusively tied to international investment law - see Christoph Schreuer and Ursula Kriebaum, 'The Concept of Property in Human Rights Law and International Investment Law' in Stephan Breitenmoser and others (eds), Human Rights, Democracy and the Rule of Law: Liber Amicorum Luzius Wildhaber (Dike 2007) 6-10. It may be revealing to discover the reasons behind the assimilation of contracts to property in the general observations of Henry Hansmann and Reinier Kraakman unrelated to international law: 'Just using the ordinary tools of contract, it is possible with sufficient effort to fashion nonpossessory rights in an asset that will bind third-party purchasers. The rules of law that offer explicit recognition of particular types of property rights simply reduce the costs of establishing those rights. Consequently, it is not quite right to say that the law limits the kinds of property rights that can be created. Rather, it is more accurate to say that there are only limited kinds of property rights whose creation the law affirmatively facilitates.' - Henry Hansmann and Reinier Kraakman, 'Property, Contract, and Verification: The Numerus Clausus Problem and the Divisibility of Rights' (2002) 10 The Harvard John M Olin Discussion Paper Series $1<$ http://www.law.harvard.edu/programs/olin_center/papers/pdf/388.pdf > accessed 25 June 2021. 
law in comparison to that offered by IIAs, ${ }^{149}$ but, more importantly, as will be clarified below, it sheds light on the lack of any specific rules in principle that can assist in ascertaining the content of contractual provisions.

By assimilating contracts to property, customary international law becomes blind or agnostic to the 'contractual nature' of contracts and therefore is not in need of any specific rule for contract interpretation. The only elements that matter are proprietary features in the contract in question and the assessment of the precise character of state interference with a contract. Verification of the existence of proprietary rights in state contracts appears to be less detailed and less nuanced an exercise if compared with the assessment of the content of contractual provisions under various standards of investment protection under international investment law. ${ }^{150}$ Monetary value, enforceability against the world at large and alienability serve as the key areas of assessment. ${ }^{151}$ While parties may disagree as to whether construction of a contract in relation to the above three points is correct, this disagreement will most likely be treated as a factual issue that befits proprietary rights and not as an interpretative issue tied to contractual rights. What the legitimate expectations are under a contract, an issue in relation to which parties frequently disagree in investment treaty arbitration and which frequently necessitates interpretation, becomes of no concern for customary international law. Because licences represent rights in personam and not in rem, ${ }^{152}$ a failure of a state to renew the licence or other permit which a foreign investor legitimately expects under an existing contract, does not as a rule grant protection under customary international law to

149 Kate Parlett gives examples of when customary international law as a background legal framework may in fact enlarge protection that is otherwise available to investments under a relevant IIA. Situations however arise when the IIA itself offers limited protection, and excludes, for instance, the FET. For more details, see Kate Parlett, 'Claims under Customary International Law in ICSID Arbitration' (2016) 31(2) ICSID Review - Foreign Investment Law Journal 434, 435-436.

150 It should be noted, however, that tribunals in investment treaty arbitration may also approach investment/investment contracts as property. For a broad overview of the approaches to investment, see Zachary Douglas, 'Property, Investment and the Scope of Investment Protection Obligations' in Zachary Douglas and others (eds), The Foundations of International Investment Law: Bringing Theory into Practice (Oxford University Press 2014) 363-406.

151 Jean Ho, State Responsibility for Breaches of Investment Contracts (Cambridge University Press 2018) 142-144, 271-272.

152 Zachary Douglas gives a more nuanced example when an alienable licence may be viewed as property - see Zachary Douglas, 'Property, Investment and the Scope of Investment Protection Obligations' in Zachary Douglas and others (eds), The Foundations of International Investment Law: Bringing Theory into Practice (Oxford University Press 2014) 363,375 . 
the said investor. In the same vein, customary international law cannot offer protection for expenditures at the pre-contractual stage. ${ }^{153}$ Until and before contracts come into existence, there are no protectable proprietary rights under customary international law in principle and when contracts do come into existence, they are of interest only as property. Once proprietary rights in a contract are verified as a precondition for the application of customary international law, the analysis immediately switches to state interference with the proprietary rights. Given the blindness of customary international law towards the 'contractual nature' of contracts and their assimilation to the property of aliens, it comes as no surprise that customary international law does not have rules on contract interpretation.

The only occasions that seem to come closer to interpretation relate to a principle that contractual forum selection clauses do not preclude the diplomatic protection or the jurisdiction of international courts or tribunals. Not only customary international law, but also general principles of law and decisions and awards of international courts and tribunals may be viewed as sources for this principle. As will be discussed at a later stage, the principle however is not a rule on contract interpretation and has nothing to do with contract interpretation. The non-exclusivity of forum selection clause in contracts, for the purpose of diplomatic protection or for the purpose of jurisdiction of international courts and tribunals, appears in another capacity as an example of the overriding application or overriding effect of international law.

The conclusion on the absence of rules for contract interpretation in investment treaty arbitration finds its further affirmation in two other examples.

153 Régis Bismuth supports this point by clarifying the absence of customary principles regulating government procurement and the absence of customary principles protecting pre-contractual expenditures - Régis Bismuth, 'Customary Principles Regarding Public Contracts Concluded with Foreigners' in Mathias Audit and Stephan W Schill (eds), Transnational Law of Public Contracts (Bruylant 2016) 334-336. For clarity, it should be noted that IIAs do not seem to offer express protection for pre-contractual expenditures - see UNCTAD, International Investment Agreements: Key Issues: Volume I (UN Doc. UnCtAd/ITE/IIt/2004/10 (Vol. I), United Nations Publication 2004) 143-16o. Even though investment treaty arbitration jurisprudence seems to also be reluctant, at least one reported case can be found offering protection - Nordzucker AG v. The Republic of Poland - see Irmgard Marboe, 'Nordzucker AG v The Republic of Poland ad hoc Arbitration (UNCItRAL), Partial Award, 10 December 2008; Second Partial Award, 28 January 2009; Third Partial and Final Award, 23 November 2009 (Vera Van Houtte, Andreas Bucher, Maciej Tomaszewski)' (2015) 16 (3) Journal of World Investment and Trade 533; Stephan W Schill, 'The Impact of International Investment Law on Public Contracts' in Mathias Audit and Stephan W Schill (eds), Transnational Law of Public Contracts (Bruylant 2016) 246-247; fn 79 and 8 o. 
Firstly, international courts or tribunals, including treaty-based tribunals in investment treaty arbitration, when engaged in contract interpretation, for various purposes and depending on their jurisdiction, do not seem to refer to any customary international law in their attempts to ascertain the content of contractual provisions. Furthermore, even contra proferentem, which some scholars in the context of treaty interpretation connect with customary international law, does not receive the same clarification when used by the international courts and tribunals in relation to contract interpretation. ${ }^{154}$

Enabling the protection of state contracts under international law, customary international law does not support an internationalisation theory in any form. The assimilation of a state contract to property for the purpose of protection under international law does not affect the proper law of a contract. Nor does an assessment of state conduct in relation to state contracts under customary international law change the proper law of a contract. Stephan Schill goes further and suggests that customary international law is not merely ambivalent to internationalisation; rather it is against it. ${ }^{155} \mathrm{~A}$ similar point can be found in the works of the most consistent opponent of the theory of internationalisation - Muthucumaraswamy Sornarajah. ${ }^{156}$ The positively accepted jurisprudence of the ICJ in recognition of the role of national law for contracts can serve as evidence of the customary rule that the mere fact of appearance of contracts in the context of disputes governed by international law does not

154 For instance, Isabelle Van Damme comparing contra proferentem to the principle of restrictive interpretation in relation to treaty interpretation clarifies that: ' $[t]$ he contra proferentem principle, in contrast, is more accepted as part of customary international law.' - see Isabelle Van Damme, Treaty Interpretation by the WTO Appellate Body (Oxford University Press 2009) 62, fn 142. In investment treaty arbitration as well as in the practice of the Iran-USA Claims Tribunal the principle of contra proferentem whenever applied to contracts was either justified by national laws (Inceysa Vallisoletana S.L. v. Republic of El Salvador, ICSID Case No. ARB/o3/26, Award dated 2 August 20o6, para. 273-276) or was applied without explaining its origin by any of the existent legal orders (William Nagelv. The Czech Republic, scc Case No.049/2002, Final Award, para. 172; Ceskoslovenska Obchodni Banka, A.S. v. The Slovak Republic, ICSID Case No. ARB/97/4, Decision of the Tribunal on Objections to Jurisdiction, para. 51; First Travel v. Government of the Islamic Republic of Iran and Iran National Airlines Corporation, Award No. 206-34-1 dated 3 December 1985, pp.15-16 <https://iusct.com/wp-content/uploads/1985/12/C34-Doc-127. pdf $>$ accessed 25 June 2021.

155 Stephan W Schill, 'The Impact of International Investment Law on Public Contracts' in Mathias Audit and Stephan W Schill (eds), Transnational Law of Public Contracts (Bruylant 2016) 237.

156 Muthucumaraswamy Sornarajah, The International Law on Foreign Investment (4th edn, Cambridge University Press 2017) 339-357. 
lead to a substitution of proper law over a contract by another regulation. ${ }^{157}$ Thus, it is not only that customary international law does not have specific rules for contract interpretation for state contracts in principle because it 'sees' property instead of 'contracts'. Importantly enough, customary international law may be further viewed as being against any attempt to disengage contracts from the relevant national law/proper law of a contract.

The analysis would not be complete, if one ignores the evolution of customary international law. Customary international law does not remain constant. ${ }^{158}$ Addressing emerging changes, some authors while openly recognising the absence of rules on certain issues that are traditionally regulated by national law, seem to be more positive in relation to the emergence of others. For instance, Régis Bismuth, recognising an absence of any rule on a form of a state contract in customary international law, points to the emergence of a concept of contract validity in [customary] international law in parallel to the national law concept of contract validity. ${ }^{159}$ Bismuth substantiates the point by referencing some cases in investment treaty arbitration. The cited cases indeed demonstrate that invalidity under national law does not constitute an absolute ground for the invalidity/non-recognition of rights under contract with only a limited number of specific grounds justifying the absolute invalidity of contracts under customary international law. While the proposition on the parallel contract-related concept of validity under customary international law may be debated, not least on grounds of the sufficiency of the cited arbitral awards to evidence the emergence of a customary rule, ${ }^{160}$ it would suffice to

157 See, for instance, Case concerning the Payment of Various Serbian Loans Issued in France; Case concerning the Payment in Gold of the Brazilian Federal Loans Issued in France, Payment in Gold of Brazilian Federal Loans Contracted in France (France v. Brazil), (Judgment of 12 July 1929) (1929) PCIJ Series A No 21.

158 Campbell McLachlan, 'Is There an Evolving Customary International Law on Investment?' (2016) 31(2) ICSID Review - Foreign Investment Law Journal 257, 257-269; Jean d'Aspremont, 'The Four Lives of Customary International Law' (2019) 21 (3-4) International Community Law Review 229.

159 Régis Bismuth, 'Customary Principles Regarding Public Contracts Concluded with Foreigners' in Mathias Audit and Stephan Schill (eds), Transnational Law of Public Contracts (Bruylant 2016) 334-341.

16o On the limited role of arbitral awards as evidence of customary international law, see, for instance, Muthucumaraswamy Sornarajah, who concludes: 'The argument in some recent awards that consistent practice among arbitral tribunals can create customary law is one that is made without an adequate understanding of international law. It arrogates a power to a group of individuals which the ICJ itself has not claimed. It is an elementary proposition that awards of tribunals are but 'subsidiary sources' of international law.' - Muthucumaraswamy Sornarajah, Resistance and Change in the International Law on Foreign Investment (Cambridge University Press 2015) 92. For a more affirmative role 
say here that no attempts have yet been made that would suggest any similar parallel emergence of a specific rule on contract interpretation in customary international law. Regarding contract interpretation, customary international law retains lacunae.

To conclude, while having a role in investment treaty arbitration and while engaging with contractual rights, customary international law does not have rules on the ascertainment of the content of contractual provisions. The principal reason for this lies in the assimilation of state contracts to property rights that customary international law maintains while offering international law protection to state contracts. ${ }^{161}$

\subsection{General Principles of Law}

Dismissing the proposition that general principles of law can play a role in contract interpretation in investment treaty arbitration is not as easy as one might assume. The primary hesitation rests on the universal character of the general principles of law and their interpretative ${ }^{162}$ and lacunae-filling functions. ${ }^{163}$ These features extend the operation of general principles to various relatively new areas of international law, including international investment

of arbitral awards, see Jean Ho, State Responsibility for Breaches of Investment Contracts (Cambridge University Press 2018) 61-89.

161 The argument advanced in this section and explanation behind it on the absence of rules on contract interpretation in customary international law does not serve as a proposition that tribunals applying customary international law should not interpret contracts. If they need to interpret, interpretation should be conducted under national law, that is, a proper law of contract. Furthermore, a mere recognition of the role of national law under customary international law confirms this proposition. The point is important, because some tribunals in investment treaty arbitration in applying IIAS, also approach contracts as property and that alone should not exclude interpretation; it merely explains a lack of interpretative rules in customary international law that does not recognise the contractual nature of contracts.

162 The interpretative function of the general principles of law even triggered doubt as to whether they are sources of international law - see Jean d'Aspremont, 'What Was Not Meant to Be: General Principles of Law as a Source of International Law' in Riccardo Pisillo Mazzeschi and Pasquale De Sena (eds), Global Justice, Human Rights and the Modernization of International Law (Springer 2018) 163-184.

163 The lacunae-filling function of the general principles of law has been long recognised ever since their formal codification in the statutes of the PCIJ and thereafter in the statutes of the ICJ - see, for instance, Michael Bogdan, 'General Principles of Law and the Problem of Lacunae in the Law of Nations' (1977) 46(1-2) Nordic Journal of International Law $37,37-53$. 
law, and augment their potential significance for those areas that remain unregulated in international law. If international law is generally silent about contract interpretation, as has been evidenced via the analysis of treaties and customary international law, it might be the case that general principles of law are capable of filling the existing gap. State contracts may be more receptive to the relevance of the general principles of law. The roots of general legal principles in national law may potentially identify their aptness, or at least their predisposition to address the interpretation of private law instruments more meaningfully than any other source of international law. Furthermore, a possible overlap between the general principles of law as recognized by the civilized nations, on the one hand, and the general principles of contract law as a reflection of a transnational legal order, on the other hand, makes it more demanding to deny the role of the general principles of law as a source of international law for contract interpretation. ${ }^{164}$ When ideas represent certain universally accepted values, the precise basis of their application, whether it be the international legal order or the transnational legal order, becomes more elusive. Ultimately, a historic aspect of the reliance on the general principles of law in choice-of-law provisions in the early concession disputes in the epoch preceding investment treaty arbitration, their use in the tribunals' reasoning, and thereafter theorisation in scholarly writings, makes it necessary to verify the relevance, if any, of these cases and resulting theories they nourish for the contemporary context of contract interpretation in investment treaty arbitration. In other words, general principles of law cannot be easily discarded and require a thorough investigation.

The starting complexity of approaching the general principles of law resembles a challenge one faces while addressing customary international law. Like customary international law, general principles of law remain uncodified. Their identification seems to be even more complicated because of the lack of uniform criteria that one can, for instance, observe in a two-fold test to identify customary international law rules. ${ }^{165}$ The comparative method is often mentioned for defining general principles through commonalities among various

164 Recognising the expanding borders of international law in terms of the scope of regulation earlier in this chapter, one also has to acknowledge that international law is considered here to be rules that are of international character and that bind states. Transnational law, while potentially overlapping in part with international law, does not bind states as such. It has an impact either through agreement or because of its pervasive character, and is essentially based on decentralised, non-state rules.

165 For criteria and challenges in the identification of the general principles of laws as sources of international law, see, for instance, Rumiana Yotova, 'Challenges in the Identification of the 'General Principles of Law Recognized by Civilized Nations': The Approach of 
national laws. ${ }^{166}$ At the same time, some of the principles have received such high recognition that they do not require one to repeatedly perform a comparative exercise. The consensus regarding their fundamental and pervasive character, supported by the reoccurrence in the reasoning of the international courts and tribunals seem to be relevant, though frequently unarticulated. By and large, it would not be improper to say that one recognises general principles when one sees them, but one faces serious difficulties in defining how to identify them.

The approach, based on the analysis of the reasoning of international courts and tribunals, informed efforts of Bin Cheng in his classical book General Principles of Law as Applied by International Courts and Tribunals, ${ }^{167}$ written in 1953, that represents one of the first and most complete empirical studies of the general principles of law. ${ }^{168}$ Subsequent scholarly works on the subject

the International Court' (2017) 3 Canadian Journal of Comparative and Contemporary Law 269 .

166 For instance, Michael Bogdan suggests that 'that the only acceptable way of determining the general principles of law goes through the use of the methods of comparative law' - see Michael Bogdan 'General Principles of Law and the Problem of Lacunae in the Law of Nations' (1977) 46(1-2) Nordic Journal of International Law 37, 49. For a critique of the methods of identification of the general principles of law, in light of the possible lessons drawn from comparative law, see Jaye Ellis, 'General Principles and Comparative Law' (2011) 22(4) European Journal of International Law 949, 949-971. It is impossible to omit how excited and rather overoptimistic scholars specialising in comparative law became in the 195os in relation to the possibility to study the general principles of law and to make a comparative exercise in various fields for international judges and arbitrators. In 1957, Rudolf B Schlesinger noted: 'No attempt has been made to find and formulate the common core of the world's legal systems in the area of substantive private law, including commercial law, and of civil procedure. Until about a year ago even the feasibility of such an attempt had not been seriously examined. During the last year, with the help and encouragement of his faculty colleagues at the Cornell Law School and of other scholars, the author has worked on the blueprint of a project designed to fill this void. The lines on the blueprint are still tentative, and perhaps a bit blurred. It is not even quite certain what the name of the project should be. Stressing its substance, one might call it "Research on General Principles of Law." - Rudolf B Schlesinger, "The Research on the General Principles of Law Recognized by Civilized Nations' (1957) 51(4) The American Journal of International Law 734, 751. Subsequently, instead of maintaining the declared broad focus on general principles of laws in private law, Rudolf B Schlesinger had to substantially narrow his research agenda to achieve a feasible result. For comparatists, he became known for the seminal 10-year international research project on contract formation - 'Formation of Contracts: A Study of the Common Core of Legal Systems.'

167 Bin Cheng, General Principles of Law as Applied by International Courts and Tribunals (Stevens \& Sons 1953).

168 At the time, the empirical method received increasing recognition under the name of the inductive approach. Bin Cheng acknowledged the influence of his supervisor George 
inescapably revolve around those principles identified by Bin Cheng. ${ }^{169} \mathrm{~A}$ practice of international courts and tribunals that has been emerging for more than 60 years since Cheng's publication has nourished further works. For instance, a book project by Charles T Kotuby and Luke A Sobota, General Principles of Law and International Due Process: Principles and Norms Applicable in Transnational Disputes, ${ }^{170}$ became of a similar breadth as Cheng's book. Drawn on the same principles as enumerated by Bin Cheng, Kotuby's and Sobota's work revisits them with the example of the modern practice of international courts and tribunals, including treaty-based tribunals. The authors make a remarkable turn from Bin Cheng's work by arguing that an evolution of the system of international justice in the time that has passed since Cheng's work demonstrates the extension of the general principles to private conduct, including asymmetric relations between states and private actors/investors in investment treaty arbitration. ${ }^{171}$ One may see in the extension, a transnational broader role that Kotuby and Sobota attribute to general principles of law that steps out of tenets of a source of international law. Unlike other discussions on the transnational legal order that frequently start from transnational ideas, lex mercatoria and the UPICC, Kotuby and Sobota start the discussion from general principles as a source of international law.

This chapter does not engage in an independent verification of the existence of the general principles of law. It limits its inquiry to those general principles of law, the existence of which remains uncontested in scholarly works, more particularly to some of those that may play a role in contract interpretation in

Schwarzenberger on the methods used in his research - Bin Cheng, General Principles of Law as Applied by International Courts and Tribunals (Stevens \& Sons 1953) XIV. On the theoretical foundation of the inductive or empirical method as clarified contemporaneously by George Schwarzenberger, see George Schwarzenberger, 'The Inductive Approach to International Law' (1947) 6o(4) Harvard Law Review 539, 539-570; see also, L C Green, International Law through the Cases (Stevens \& Sons 1970) and Clarence Wilfred Jenks, The Prospects of International Adjudication (Stevens \& Sons 1964) 617-662.

169 Published in 1953, Bin Cheng's General Principles of Law as Applied by International Courts and Tribunals were reprinted three times, in 1987, 1994 and 2006. Charles T Kotuby Jr and Luke A Sobota recognise that Cheng's work is 'among the most cited authorities in international arbitration' - see Charles T Kotuby Jr and Luke A Sobota, General Principles of Law and International Due Process: Principles and Norms Applicable in Transnational Disputes (Oxford University Press 2017) xiii.

170 Charles T Kotuby Jr and Luke A Sobota, General Principles of Law and International Due Process: Principles and Norms Applicable in Transnational Disputes (Oxford University Press 2017).

171 Ibid. xii-xiv. The transnational nature of general principles seems to be a primary, underlying idea behind Kotuby's and Sobota's work, which is also partially reflected in the title of the book that points to transnational disputes. 
an adjudicative setting of public international law. Furthermore, since general principles of law may find their expression through other sources of international law, such as treaties and customary international law, ${ }^{172}$ general principals of law are analysed here if and when applied in their own name.

The separation of those general principles of law that potentially matter for contract interpretation represents another complexity. Looking at the principles that Cheng named in his Draft Code of General Principles of Law, purely for interstate application, ${ }^{173}$ and at those that Kotuby and Sobota reiterate with their broader perspective, ${ }^{174}$ one can distinguish two categories of general principles. The first category relates to general principles that bear substantive regulation, and include good faith, proportionality, principles of causation and reparation, and principles of responsibility and fault. The second category relates to those general principles that become relevant for various procedural aspects of dispute resolution, and includes principles of judicial independence and impartiality, procedural equality and the right to be heard, condemnation of fraud and corruption, and the principle of res judicata. General principles in the first category may mimic national law regulation when addressed to contractual material, and are thus capable of assisting to a certain degree to contract construction. One principle, the principle of good faith, is even more relevant ${ }^{175}$, and it is this principle alone that Kotuby and Sobota rely upon when they illustrate the role of the general principles for contract interpretation. The

172 For instance, the principle of pacta sunt servanda may appear as a principle of international law, a part of customary international law and an express treaty provision in the vCLT. Tarcisio Gazzini helpfully clarifies that: ‘ $\mathrm{g}]$ eneral principles of law derived from national system interact with the other sources of international law too. They may develop into customary rules, find their way in treaties, or fill the gaps of both treaties and customs. Treaty rules, customary international rules and general principle of law are by no means mutually exclusive categories.' - see Tarcisio Gazzini 'General Principles of Law in the Field of International Investment Law' (2009) 9(1) Journal of World Investment \& Trade 1, 3. See also on interrelations of sources of international law in the context of international investment law, Christoph Schreuer, 'Sources of International Law: Scope and Application: Emirates Lecture Series 28' (The Emirates Center for Strategic Studies and Research) <https://www.univie.ac.at/intlaw/sources.pdf >, accessed 25 June 2021.

173 Appendix 1 'Draft Code of General Principles of Law' in Bin Cheng, General Principles of Law as Applied by International Courts and Tribunals (Stevens \& Sons 1953) 397-399.

174 Annex of cases in Charles T Kotuby Jr and Luke A Sobota, General Principles of Law and International Due Process: Principles and Norms Applicable in Transnational Disputes (Oxford University Press 2017) 211-271.

175 Focused on inter-state relations, and writing before the VCLT, Cheng mentions the role of good faith in treaty relations, good faith in the exercise of rights in interstate relations and some other applications of the principle - see Bin Cheng, General Principles of Law as Applied by International Courts and Tribunals (Stevens \& Sons 1953) 105-162. 
analysis exercised here will be, accordingly, narrowed to the relevance of the general principle of good faith as a possible source of international law for contract interpretation. ${ }^{176}$

Addressing good faith as the general principles of law, the source of international law, for contract interpretation, makes it important to place the discussion in a broader context of good faith as an idea that informs numerous concepts, rules and principles in national law, international law and transnational law and as a foundation for interpretative approaches under these legal orders. At a very high level of abstraction, largely balancing, complementing and correcting functions of good faith as an idea have a persuasive appeal of universality. One can argue that good faith becomes inherent to the very notion of law, becomes its 'irreducible predicate,',77 and finds its natural expression in all three legal orders - in international law, in national law and in transnational law. Unsurprisingly, one can trace an idea of good faith in numerous recognised forms in investment treaty arbitration. Good faith informs various concepts, rules and principles, expressly and implicitly. Good faith informs the content of legitimate expectations, the concept that forms a central part of various substantive standards of investment protection, including FET , 178 expropriation, ${ }^{179}$ umbrella clauses, ${ }^{180}$ etc. The concept is also frequently invoked

${ }_{17}$ Remarkably, in one of the most complete and comprehensive book projects on the effect of general principles in investment arbitration, no general principles applicable to contract interpretation are identified and discussed - see Andrea Gattini, Attila Tanzi and Filippo Fontanelli (eds), General Principles of Law and International Investment Arbitration (Nijhoff 2018).

177 Charles T Kotuby Jr and Luke A. Sobota, General Principles of Law and International Due Process: Principles and Norms Applicable in Transnational Disputes (Oxford University Press 2017) 88-89.

${ }_{17}$ For a comprehensive overview of the role of good faith in FET, see Martins Paparinskis, 'Good Faith and Fair and Equitable Treatment in International Investment Law' in Andrew D Mitchell and others (eds), Good Faith and International Economic Law (Oxford University Press 2015) 143-172; Rumana Islam, 'Role of Good Faith in Interpreting Fair and Equitable Treatment (FET) Standard in Arbitral Practice' (2017) 12(1-2) Bangladesh Journal of Law 107; Rudolf Dolzer, 'Fair and Equitable Treatment: Today's Contours' (2014) 12(1) Santa Clara Journal of International Law 7; Campbell McLachlan, 'Investment Treaties and General International Law' (2008) 57(2) The International and Comparative Law Quarterly 361, 380-401.

179 See, for instance, a discussion on public interest in expropriation - Andrew Paul Newcombe and Lluís Paradell, Law and Practice of Investment Treaties: Standards of Treatment (Kluwer Law International 2009) 370.

180 See, for instance, Greece-Serbia and Montenegro BIT 1997 Article 2: 'Promotion and protection of investment ... (4) Each Contracting Party shall, in its territory, respect in good faith all obligations concerning a particular investor of the other Contracting Party undertaken within its legal framework.' 
as a state's defence in opposing the jurisdiction or admissibility of a case. ${ }^{181}$ Examples of the concept may be found in the analysis of corporate structures for deciding on protected investments. ${ }^{182}$ Good faith is also frequently called upon to measure the appropriateness of the parties procedural behaviour. ${ }^{183}$ As a source of international law - a general principle of law - good faith can turn into part of a substantive regulation along with IIAs, ${ }^{184}$ etc.

Given the pervasiveness of the idea of good faith, one can, to a certain extent, align the role of good faith across international and national laws: good faith as a principle of international law and as an overarching principle of civil/ contract laws (in civil law jurisdictions); good faith as a recognised interpretative tool for treaty interpretation and good faith as an interpretative standard for contract interpretation (again in civil law jurisdictions). The appearance of interchangeability, though, is deceptive. Despite numerous natural parallels and overlaps because of the inherent idea of bona fide in various legal concepts, ${ }^{185}$ good faith is conceptualised somewhat differently in the three legal orders - international law, national law and transnational law. ${ }^{186}$

181 Tania Voon, Andrew D Mitchell and James Munro, 'Good Faith in Parallel Trade and Investment Disputes' in Andrew D Mitchell and others (eds), Good Faith and International Economic Law (Oxford University Press 2015) 6o-87; Muthucumaraswamy Sornarajah, 'Good Faith, Corporate Nationality, and Denial of Benefits' in Andrew D Mitchell and others (eds), Good Faith and International Economic Law (Oxford University Press 2015) 117142; Chittharanjan Félix Amerasinghe, Jurisdiction of International Tribunals (Martinus Nijhoff Publishers 2003) 305; Chittharanjan Félix Amerasinghe, International Arbitral Jurisdiction (Martinus Nijhoff Publishers 2011) 100-101.

182 Stephan W Schill and Heather L Bray, 'Good Faith Limitations on Protected Investments and Corporate Structuring' in Andrew D Mitchell and others (eds), Good Faith and International Economic Law (Oxford University Press 2015) 88-116.

183 Eric de Brabandere, 'Good Faith', 'Abuse of Process' and 'the Initiation of Investment Treaty Claims' (2012) 3(3) Journal of International Dispute Settlement 6og.

184 For instance, some IIAs expressly recognise the role of the general principles of law as applicable regulation - see Article 17 (1) of the United Kingdom-Mexico BIT (2006) (in force) or Article 13 (5) the Netherlands-Bolivia BIт (1992) (terminated).

185 Views on good faith as a principle reinforce an impression of a certain degree of highlevel universality that it possesses. For good faith as a principle of international law, see Robert Kolb, 'Principles as Sources of International Law (With Special Reference to Good Faith)' (2006) 53(1) Netherlands International Law Review 1, 1-36; Robert Kolb, Good Faith in International Law (Hart Publishing 2017) 3-37. For good faith as a principle in civil law jurisdictions, see Hugh Collins (ed), Standard Contract Terms in Europe: A Basis for and a Challenge to European Contract Law (Kluwer Law International 2008) 237 .

186 Steven Reinhold, for instance, helpfully clarifies the distinction as follows: 'In national law, good faith acts to balance out unequal sides of a bargain. In international law this asymmetrical power balance, whether real or perceived, is absent. The principle of sovereign equality of nations dictates that there is no 'weak party' to a bargain in international law: by 
Upon deeper investigation, one will face a plurality of distinctions in the application of good faith, depending on whether its specific source is international, national or transnational law. These sources define whether and to what extent good faith imposes a standard of behaviour for actors in the exercise of their authority, discretion or rights, whether and to what extent good faith assists to ensure equality between the parties, and whether and to what extent good faith leads to corrective justice, etc.

The examples relating to interpretation of various instruments that follow illustrate the differences.

In the VCLT, good faith opens the general rule of treaty interpretation in Article 31: 'A treaty shall be interpreted in good faith in accordance with the ordinary meaning to be given to the terms of the treaty in their context and in the light of its object and purpose.' Despite the appearance of simplicity, the precise intent of the drafters behind the inclusion of 'good faith' in a rule on treaty interpretation is not easy to establish. A thorough investigation of the travaux préparatoires evidences that a reference to good faith appeared as a result of complex circumstantial discussions, without being directly informed by any of the specific roles good faith plays in national laws.

According to the travaux préparatoires of the VCLT, good faith first appeared in the discussion as an extension of the principle that treaties shall be performed in good faith. ${ }^{187}$ While referring to good faith in interpretation, the International Law Commission did not even decide whether, after all, it would be advisable to have a separate provision focused on the methods of treaty

\footnotetext{
"entering the Family of Nations a State comes as an equal to equals". This does not necessarily mean that States are completely equal as regards power, territory, and the like. But as States, they are legally equal, at least in principle, whatever differences between them may otherwise exist. As a result, even though sovereign equality can still serve to protect weaker States from the hegemony of stronger States, the fundamental conception of good faith as a means of corrective justice is not directly applicable to the relations between States.' - see Steven Reinhold, 'Good Faith in International Law' (2013) 2 Bonn Research Paper on Public International Law 1 <https://papers.ssrn.com/sol3/papers.cfm?abstract_id=2269 746> accessed 25 June 2021. See also Giuditta Cordero-Moss listing the concept of 'good faith' among 'the false friends' in public international law and national commercial laws in Giuditta Cordero-Moss, 'Commercial Arbitration and Investment Arbitration: Fertile Soil for False Friends?' in Christina Binder and others (eds), International Investment Law for the 21st Century: Essays in Honour of Christoph Schreuer (Oxford University Press 2009) 782,789 .
}

187 Sir Humphrey Waldock, 'Third Report on the Law of Treaties, by Sir Humphrey Waldock, Special Rapporteur' (A/CN.4/167, 1964) 2 Yearbook of the International Law Commission 5, $5^{2-} 57<$ http://legal.un.org/ilc/documentation/english/a_cn4_167.pdf > accessed 25June 2021. 
interpretation. Rather than presenting a self-standing canon of treaty interpretation, a provision just affirmed a proposition that was not controversial per se. Namely, if treaties are to be performed in good faith, they have to be interpreted in good faith by contracting parties as well. This extension of the pacta sunt servanda principle towards interpretation tied for some authors the origin of good faith in treaty interpretation to good faith in contract interpretation. ${ }^{188}$ The connection, though, is nothing but pure analogy. Good faith as it is understood in private law - as an overarching principle of contract/civil law and an important tool for contract interpretation under some national laws has not informed the content of good faith in the mentioned proposition. Nor, as will be demonstrated below, has it informed the inclusion of good faith in the subsequently elaborated Article 31 , focused on the methods of treaty interpretation.

When the drafting group of the ILC decided to have provisions on treaty interpretation and turned to the discussion of canons and the principle of treaty interpretation in what is presently Article $3^{1}$ of the VCLT, good faith emerged again. The Special Rapporteur, Sir Humphrey Waldock, tied good faith again to the principle of pacta sunt servanda, at the same time recognising that an idea of integrity was also of good faith. ${ }^{189}$ Efficiency Waldock put into a separate provision - Article 72 'Effective interpretation of the terms' ( $u t$ res magis valeat quam pereat). ${ }^{190}$ Being supportive of the role of good faith,

188 Propositions on similarities follow a widely cited statement by Hersch Lauterpacht, who said: 'Most of the current rules of interpretation, whether in relation to contracts or treaties ... are no more than the elaboration of the fundamental theme that contracts must be interpreted in good faith.' - Hersch Lauterpacht, 'Restrictive Interpretation and the Principle of Effectiveness in the Interpretation of Treaties' (1949) 26 British Yearbook of International Law 48, 56. See, for instance, Eric De Brabandere and Isabelle Van Damme who start their analysis of good faith in treaty interpretation with an analogous comparison with the interpretation of contracts in good faith, citing Hersch Lauterpacht - Eric De Brabandere and Isabelle Van Damme 'Good Faith in Treaty Interpretation' in Andrew D Mitchell, Muthucumaraswamy Sornarajah and Tania Voon, Good Faith and International Economic Law (Oxford University Press 2015) 37. To the authors' knowledge, no deep inquiry into the comparison of good faith in treaty interpretation and good faith in contract interpretation has been exercised, but see a comprehensive overview of various facets of the role of good faith in investment treaty arbitration with a concept built on a summary of its use in international law and national laws in Emily Sipiorski, Good Faith in International Investment Arbitration (Oxford University Press 2019) 20-47.

189 Sir Humphrey Waldock, 'Third Report on the Law of Treaties' (A/CN.4/167, 1964) 2 Yearbook of the International Law Commission $5,5^{6}<$ http://legal.un.org/ilc/documentat ion/english/a_cn4_167.pdf> accessed 25 June 2021.

190 Sir Humphrey Waldock, 'Third Report on the Law of Treaties' (A/CN.4/167, 1964) 2 Yearbook of the International Law Commission 5, $53<\mathrm{http}$ //legal.un.org/ilc/documentat ion/english/a_cn4_167.pdf> accessed 25 June 2021. 
six principles of treaty interpretation prepared by Sir Gerald Fitzmaurice ${ }^{191}$ and the 1956 Resolution of the Institute of International Law ${ }^{192}$ informed his efforts. ${ }^{193}$ Looked at nowadays, both integrity and efficiency seem to form an inseparable package of what interpretation in good faith means to Article 31 of the VCLT. ${ }^{194}$ The fact that both Sir Gerald Fitzmaurice and Sir Humphrey Waldock were British lawyers and that good faith is not an overarching principle for English contract law, ${ }^{195}$ may reinforce the view that national law did not inform the content of good faith in its appearance among methods of treaty interpretation.

Subsequent discussion within the ILC evidences how good faith 'absorbed' a separate provision on efficiency and offered safe tenets for consensus. As the discussion proceeded after Waldock introduced a separate provision on efficiency, a tension arose between those who wanted to have a principle of effectiveness to be inserted into the VCLT as a self-standing provision and those who affirmed the principle of effective interpretation, but not as an independent provision. Furthermore, a substantial schism between capitalist and communist blocks burdened the overall work on the text: the former preferred intentionalism and the latter preferred textualism. ${ }^{196}$ The ultimate reference to good faith in the opening paragraph of Article 31 safeguarded all interests. Treaties had to be interpreted 'in good faith' to impose a discipline on interpreters and to secure that all tools of interpretation would be used properly. The contemporaneous explanation emphasised the connecting role of good faith between all elements of treaty interpretation and, more importantly,

191 Gerald Fitzmaurice, 'The Law and Procedure of the International Court of Justice 1951-4: Treaty Interpretation and Other Treaty Points' (1957) 33 British Yearbook of International Law 203 .

192 The 1956 Resolution of the Institute of International Law available at <http://www.idi-iil. org/app/uploads/2017/o6/1956_grena_o2_fr.pdf>, accessed 25 June 2021.

193 Sir Humphrey Waldock, 'Third Report on the Law of Treaties' (A/CN.4/167, 1964) 2 Yearbook of the International Law Commission 5,55 <http://legal.un.org/ilc/documentat ion/english/a_cn4_167.pdf> accessed 25 June 2021.

194 Oliver Dörr and Kirsten Schmalenbach (eds), Vienna Convention on the Law of Treaties: A Commentary (1st edn, Springer 2012) 540, 548 .

195 One may also argue though that a cautious attitude to good faith under English contract law did not impede active contribution to the drafting of the CISG, an observation that is made in contemporary literature advocating the attractiveness of the CISG for the UK. For instance, on reasons for the UK to refuse accession tied with the distinctions in contract regulation to the CISG, see Nathalie Hofmann, 'Interpretation Rules and Good Faith as Obstacles to the UK's Ratification of the CISG and to the Harmonization of Contract Law in Europe' (2010) 22(1) Pace International Law Review 145.

196 Fuad Zarbiyev, 'A Genealogy of Textualism in Treaty Interpretation' in Andrea Bianchi and others (eds), Interpretation in International Law (Oxford University Press 2015) 74. 
between purposive and textual readings of a treaty: 'An interpretation given in good faith and taking account of the object and purpose of a treaty would always necessarily seek to give a meaning to the text. ${ }^{\prime 197}$ Rather than being informed by considerations of national law, good faith, in treaty interpretation, became a product of consensus.

Corresponding to these (complex) original expectations, the contemporaneous function of good faith in treaty interpretation in investment treaty arbitration has a plurality of appearances, valuably summarised by Eric De Brabandere and Isabelle Van Damme:

Good faith may thus be used to justify: the use of certain principles of treaty interpretation above others: the use of other tools, principles or values that can be taken into account in interpreting treaties (such as the principle of effectiveness); the choice of what preparatory work to use in relying on supplementary means of treaty interpretation; or reliance on other (relevant) rules of international law. Good faith can also justify completing treaties with content that is not expressly stated and complementing treaties with norms of customary international law or general principles of law, including the principle of good faith itself. The principle of good faith equally functions as a limit on the exercise of discretion that any interpretative analysis involves and thus the exercise of judicial or judicial-like powers. ${ }^{198}$

Instead of vagueness, the plurality of examples in which good faith can be relied upon in treaty interpretation demonstrates its context-dependence. What remains clear is that good faith was not considered to be a bare escape from textualism. It was supposed to connect and calibrate all elements of treaty interpretation, ${ }^{199}$ to justify interpretative choices under certain premises, in order to ensure what is fair and reasonable under given circumstances, and, where relevant, to reinforce their textual meaning. Furthermore, while

\footnotetext{
197 International Law Commission, 766th meeting minutes dated 15 July 1964, (1964) 1 Yearbook of the International Law Commission 290, para. 106 (chairman of ILC Roberto Ago speaking as a member of the Commission).

198 Eric De Brabandere and Isabelle Van Damme, 'Good Faith in Treaty Interpretation' in Andrew D Mitchell and others (eds), Good Faith and International Economic Law (Oxford University Press 2015) 59.

199 Richard Gardiner emphasises that 'not only was the scene set for a broad view of good faith but that concept was also aligned from the start with other elements of the general rule, such as the role of object and purpose' - see Richard Gardiner, Treaty Interpretation (2nd edn, Oxford University Press 2015) 170.
} 
the reach of good faith seems to be broad, one should not omit a view that emphasises the dominant textualism in treaty interpretation that emerges regardless of the plurality of methods as envisaged in Article 31 of the VCLt. ${ }^{200}$ According to this view, as a matter of practice and regardless of the introduction of good faith and numerous other tools on treaty interpretation in the VCLT, textualism which was quite dominant at the time of the VCLT's drafting, ${ }^{201}$ developed into a prevailing approach. ${ }^{202} \mathrm{An}$ indirect understanding of this trend can be seen in how modern treaties are drafted in ever-increasing detail within texts. ${ }^{203}$ Importantly for the present discussion, other considerations distinct from the ordinary operation of good faith for contract interpretation in national laws inform its appearance and its actual application in treaty interpretation.

In what relates to good faith in transnational, non-state regulation, instruments such as, for instance, the PECL and the UPICC, ${ }^{204}$ are difficult to understand autonomously from the national legal traditions. ${ }^{205}$ Despite the attempts of their drafters to find truly neutral grounds, differences in the role of good

200 Fuad Zarbiyev, 'A Genealogy of Textualism in Treaty Interpretation' in Andrea Bianchi and others (eds), Interpretation in International Law (Oxford University Press 2015) 251-267.

201 It is interesting to observe how Waldock explains dominant textualism noting that the report 'accepts the view that the text must be presumed to be the authentic expression of the intention of the parties' and that 'the Institute of International Law adopted this - the textual - approach to treaty interpretation, despite its first Rapporteur's [H Lauterpacht] strong advocacy of a more subjective, 'intentions of the parties', approach' - Sir Humphrey Waldock, 'Third Report on the Law of Treaties, by Sir Humphrey Waldock, Special Rapporteur' (A/CN.4/167, 1964) 2 Yearbook of the International Law Commission 5 <http://legal.un.org/ilc/documentation/english/a_cn4_167.pdf>, accessed 25 June 2021.

202 On changes of the approaches towards textualism in time and on primary operation of the plain and ordinary meaning in treaty interpretation under the VCLT, see also Alexander Orakhelashvili, The Interpretation of Acts and Rules in Public International Law (Oxford University Press 2008) 301-322.

203 Certain similarities can be drawn from extensive and rather detailed contracts subjected to English law and more extensive and detailed treaties concluded by states. New generations of FTAs serve as a good illustration for detailed and voluminous treaties.

204 Though the UPICC and the PECL are referred to as non-state transnational instruments, one can find numerous areas that are influenced by the national laws of certain jurisdictions. While I refer to express provisions here, one can however find expression of the principle of good faith in provisions on integrity and efficiency of interpretation in which good faith was not formally mentioned. For the PECL - Articles 5:105, Article 5:106; for the UPICC - Article 4.4, Article 4.5.

205 See, for instance, some observations in Giuditta Cordero-Moss, 'Lectures on Comparative Law of Contracts' (2004) 166 Publications Series of the Institute of Private Law, University of Oslo $132-134$. 
faith can be spotted even on a perfunctory level. While the PECL expressly features good faith among relevant circumstances for contract interpretation, ${ }^{206}$ the UPICC attributes this role to good faith for supplying the omitted terms ${ }^{207}$ and omits a reference to good faith in a general provision featuring the relevant circumstances for contract interpretation. ${ }^{208}$ Even the contra proferentem rule receives somewhat different wording that might affect its ultimate application. While the PECL extends the rule to 'doubts' about the meaning of contract terms, ${ }^{209}$ the UPICC links it to the 'unclarity' of the term. ${ }^{210}$

Furthermore, differences and nuances in approaches towards good faith do not only appear between legal orders: the national contract laws of various states differ dramatically between themselves in the role allocated to good faith. What is more, and as illustrated in Chapter 2, good faith informs the fundamental distinctions in contract interpretation under national laws across various legal traditions. The span ranges from an overarching principle and a powerful mechanism for control over the contractual content to a categorical rejection of its role in interpretation with the recognition of only a very limited role on certain precisely defined occasions.

The identified differences in the operation of good faith as a part of various legal orders makes it necessary to look at its precise function as a general principle of law, a source of international law, and in contract interpretation, if there is any precise function one can distil. First, this chapter will consider the analysis and examples given by Kotuby and Sobota on the application of the principle for contract interpretation in investment arbitration. Thereafter the work will attempt to identify and look independently at occasions when good faith was raised or relied upon in investment treaty arbitration for contract interpretation as a general principle of law in its own name, disengaged from national law and transnational law.

According to Kotuby and Sobota, the principle of good faith matters for ensuring contract performance (pacta sunt servanda), for excusing contractual performance and for remedying non-performance. Each of the identified areas in which good faith operates may require contract interpretation. When applied for interpretative purposes, good faith finds expression in three sub-principles. Firstly, good faith appears as a demonstration of a principle of integrity - ut res magis valeat quam pereat ('no construction shall be admitted

206 Article 5:102 of the PECL.

207 Article 4.8 of the UPICC.

208 Article 4.3 of the UPICC.

209 Article 5:103 of the PECL.

210 Article 4.6 of the UPICC. 
which renders a [contract] null and illusive, nor which leaves it in the discretion of the party promising to fulfil or not their promise'). ${ }^{211}$ Secondly, good faith appears as a demonstration of effectiveness (interpretation of 'an agreement as a whole to achieve its purpose and aim, which ensures that individual words or phrases within the agreement are given meaning, force, and effect'). ${ }^{212}$ Thirdly and finally, according to Kotuby and Sobota, good faith appears as a foundation of the contra proferentem principle.

The first two expressions of good faith essentially reflect the holistic ideas of taking a contract as a whole and of not depriving a single term of its significance. These approaches to interpretation hardly require any external justification, be that general principles as a source of international law or general principles as an emanation of a transnational legal order, or more generally international law, national law and transnational law. ${ }^{213}$ Alexander Orakhelashvili helpfully notes the limits of holistic approaches to treaty interpretation that retain validity in the context of contract interpretation. He notes, in particular, that a holistic approach does not present a method of interpretation, but it rather leads to 'the balance of interpretative outcomes under particular methods of interpretation.214 Importantly, holistic functions/derivatives of the principle of good faith as a general principle of law differ from the ordinary and conventional operation of good faith in contract interpretation as a concept of national (civil/contract) law in civil jurisdictions. Rather than operating to ensure that neither term is unduly discarded and an agreement is treated as a whole, good faith under national laws operates mostly for corrective

211 Charles T Kotuby Jr. and Luke A Sobota, General Principles of Law and International Due Process: Principles and Norms Applicable in Transnational Disputes (Oxford University Press 2017) 97, reference in fn 59 .

212 Ibid. 97-98.

213 Holistic approaches to contract construction reflect hermeneutic principles based on an understanding of the words in context. In other words, the method is inherent to the nature of language and does not require external justifications. Stefan Vogenauer, for instance, in his Commentary on similar provisions in reference to 'a contract as a whole' in Article 4.4. emphasises the hermeneutic foundation of the provision, whereas in relation to 'all terms to be given effect' in Article 4.5 of the UPICC - the common sense of the provision, see Stefan Vogenauer and Jan Kleinheisterkamp (eds), Commentary on the UNIDROIT Principles of International Commercial Contracts (PICC) (1st edn, Oxford University Press 2009) 521, 524. At the same time, some national laws may expressly codify holistic principles as a part of the rules for contract interpretation. For instance, Article 20 of the Law of Obligations and Contracts of Bulgaria and Article 1.267 of the Civil Code of Romania.

214 Alexander Orakhelashvili, The Interpretation of Acts and Rules in Public International Law (Oxford University Press 2008) 311. 
interpretation in extreme cases. This corrective application, addressed in a comparative perspective in Chapter 2, works in reverse order by precisely discarding the significance of some contractual terms because of the unfair implications they bring.

In what relates to the third and probably the most characteristic example of the application of the general principles of law to contract interpretation out of those that Kotuby and Sobota name, contra proferentem, one cannot omit scepticism. While indeed being premised on good faith, whenever applied to contracts, the contra proferentem rule nevertheless depends on the applicable national law and the operation of good faith under that particular law. Comparative analysis demonstrates distinctions in the application of contra proferentem across various jurisdictions. ${ }^{215}$ A distinction drawn by Alexander Orakhelashvili between principles of interpretation and interpretative maxims in the context of treaty interpretation is again helpful here. According to Orakhelashvili, maxims or canons of interpretation, including contra proferentem, do not possess an independent legitimacy, or normativity, and may be applied 'in so far as they constitute the application of the principles of interpretation'.216 In the context of treaty interpretation, being an uncodified canon of interpretation, contra proferentem is not a recognised principle or rule of treaty interpretation. It can only be applied through rules on treaty interpretation. Sean D Murphy is even more clear about why one should apply canons of interpretation to treaty interpretation with care: '... the invocation of a canon as requiring a particular outcome may be an attempt to mask with legal jargon the interpreter's own policy preference, even when invoked simply as an interpretative aide, such canons must be used with caution taking full account of the context at issue.217 In the same vein, contra proferentem when applied to contract interpretation does not bear universal independent legitimacy and can only be applied for contract interpretation so far as an applicable national law permits or justifies it.

215 Péter Cserne, 'Policy Considerations in Contract Interpretation: the Contra Proferentem Rule from a Comparative Law and Economics Perspective' (2007) 5 Hungarian Association For Law and Economics Working Paper <http://citeseerx.ist.psu.edu/ viewdoc/download;jsessionid=16418DDB5B3905 $55577040 B F 61 D A C E 10 ? d o i=10.1 .1 .624 .5797 \&$ rep=rep1\&type $=\mathrm{pdf}>$ accessed 25 June 2021.

216 Alexander Orakhelashvili, The Interpretation of Acts and Rules in Public International Law (Oxford University Press 2008) 317.

217 Sean D Murphy, 'The Utility and Limits of Canons and Other Interpretative Principles in Public International Law' in Joseph Klinger, Yuri Parkhomenko and Constantinos Salonidis (eds), Between the Lines of the Vienna Convention? Canons and Other Principles of Interpretation in Public International Law (Kluwer Law International 2018) 13, 23. 
Given these points, it is not surprising that both examples on contra proferentem that Kotuby and Sobota raise to illustrate the operation of the principle of good faith in its proper name (i.e. disengaged from national law) to contract interpretation in the field of contract-based and treaty-based investment arbitration are problematic. While a discussion on contra proferentem in Ceskoslovenska Obchodni Banka v. The Slovak Republic ${ }^{218}$ was not indeed formally corroborated by reliance on national law, ${ }^{219}$ the tribunal did not rely on the principle, but rather rejected it in one sentence. What is more, the tribunal construed the contract in question - the financial consolidation agreement concluded among the Czech Republic, the Slovak Republic and čso in relation to the bank's financial restructuring (the Consolidation Agreement) - by relying on Czech law applicable to it and not general principles of law as a source of international law. ${ }^{220}$ In the treaty-based case of Int'L Thunderbird Gaming Corp. v. United Mexican States, ${ }^{221}$ Thomas Wälde indeed introduced contra proferentem as a general principle, in his words, 'a traditional international law principle. ${ }^{222}$ However, Wälde suggested a principle for interpretation of a unilateral act - an 'interpretative assurance' or a 'comfort letter' provided to the Secretary of the Interior, and not for contract interpretation, and only in a separate opinion unsupported by other members of the tribunal. ${ }^{223}$ In light of the above, it can hardly be accepted that the presence of the idea of good faith in contra proferentem raises the rule to a general principle of law applied in its name proper.

Given the limited number of examples that Kotuby and Sobota provide to illustrate how the principle of good faith operates for contract interpretation in investment arbitration, an independent empiric verification becomes necessary. An analysis of awards in investment treaty arbitration reveals two distinct problems inherent to the notion of good faith. For the first, there are cases in investment treaty arbitration with express reliance on good faith in the context

218 The case of Ceskoslovenska Obchodni Bankav. The Slovak Republic is essentially a contractbased case. The Czech-Slovakia BIT did not come into force and was applied by the tribunal exclusively as a part of the parties' agreement.

219 Ceskoslovenska Obchodni Banka v. The Slovak Republic, ICSID Case No. ARB/97/4, Decision of the Tribunal on Objections to Jurisdiction dated 24 May 1999, para. 55 .

220 Ceskoslovenska Obchodni Banka v. The Slovak Republic, ICSID Case No. ARB/97/4, Award dated 29 December 2004, para. 52, 58-68.

221 International Thunderbird Gaming Corporation v. The United Mexican States, UNCITRAL, Arbitral Award dated 26 January 2006.

222 International Thunderbird Gaming Corporation v. The United Mexican States, UnCITRAL, Separate Opinion of Thomas Wälde, dated 1 December 2005, para. 5 .

223 Ibid. para. 6. 
of contract construction, but in the absence of the tribunal's explanation, it may prove difficult to recognise that good faith actually operates as a general principle. ${ }^{224}$ McNair's observation in 1961 on the difficulty 'to give the expression of the precise meaning 225 in frequent reliance on good faith in judicial reasoning retains its validity nowadays. For the second, there are various other cases in which tribunals relied on efficiency and integrity in contract construction but were silent as to the possible ties of the exercised approach with the principle of good faith as a source of international law.226 Tying justification that relies on efficiency and integrity to the principle of good faith now instead of tribunals may be an undue stretch. Bearing in mind these difficulties, priority is given only to those cases that contain an express reliance on good faith in relation to the ascertainment of the content of contractual provisions and that mark good faith as a principle. As striking as it can be, only one case out of those analysed - Azurix Corp. v. The Argentine Republic ${ }^{227}$ - satisfies the criteria on a prima facie basis. In the case, the tribunal relied on the maxim exceptio non adimpleti contractus (exception due to a contractual breach) in relation to concession, expressly attributing it to the principle of good faith. ${ }^{228}$ The prima facie fitness of the case would be rejected though, on a more detailed analysis,

224 In Swisslion v. Macedonia, for instance, the tribunal extensively referred to good faith in an interpretation of a share sale agreement. Reliance did not, however, constitute an independent good faith construction that the tribunal exercised. The tribunal was rather satisfied that given the ambiguity of the contractual terms, both parties to the contract could disagree on the construction 'in good faith', and therefore the application by the state to a national court for the termination of the share sale agreement was not in bad faith per se (Award dated 6 July 2012, para. 266). In ICS Inspection and Control Services Limited $v$. the Argentine Republic(I), for instance, the respondent attempted to base a legal argument on good faith as part of a holistic interpretation, stressing that disregarding the language of a forum selection clause by the claimant was contrary to good faith (para. 167-168 of the Award on jurisdiction of 10 February 2010). Good faith was called to reinforce the textual integrity - the content of the forum selection clause. The tribunal denied jurisdiction on other arguments advanced by the respondent and has not reacted to the argument based on good faith, however. For a critique of minimalism in legal reasoning, see also Federico Ortino, 'Legal Reasoning of International Investment Tribunals: A Typology of Egregious Failures' (2012) 3(1) Journal of International Dispute Settlement 31, 31-52.

225 Arnold McNair, Law of Treaties (Clarendon Press 1961) 465.

226 See, for instance, Millicom International Operations B.V. and Sentel GSM SA v. The Republic of Senegal, ICSID Case No. ARB/o8/20, Decision on Jurisdiction of the Arbitral Tribunal dated 16 July 2010, para. 98; Biwater Gauff (Tanzania) Ltd. v. United Republic of Tanzania, ICSID Case No. ARB/ 05/22, Award dated 24 July 2008, para. 495-496.

227 Azurix Corp. v. The Argentine Republic (I), ICSID Case No. ARB/o1/12, Award dated 14 July 2006.

228 Ibid. para. 26 o. 
thus leaving untouched the sceptical view on the independent and immediate role of the general principles of law as a source of international law for contract interpretation.

In Azurix Corp. v. The Argentine Republic, a dispute arose in relation to the 30-year concession concluded between an Argentinian subsidiary of the American corporation, Azurix Corp., and the Province of Buenos Aires regarding the distribution of drinkable water and the treatment of sewage in the Province. Under the concession agreement, the Province had to fulfil its undertakings in relation to completion of the infrastructure repair works. The failure to do so resulted in an algae outbreak that contaminated the water, rendering it unfit for human consumption. The government, however, blamed an investor for this failure and encouraged consumers not to pay bills to the concessioner. Furthermore, the provincial authorities precluded the Argentinian subsidiary of Azurix Corp. from increasing tariffs. Experiencing negative economic consequences as a result of the cumulative acts of the provincial and governmental authorities, the concessioner terminated the contract. The Province, however, rejected the termination, and only after the concessioner filed for bankruptcy, did the Province terminate the concession, referring to the failures of the concessioner to perform its undertakings under the concession. Bringing the case to the ICSID, Azurix Corp. claimed that Argentina was responsible for indirect expropriation, for violation of FET, full protection and security, and an umbrella clause, as well as for arbitrary, unreasonable, and/ or discriminatory measures. The tribunal found that Argentina had violated the FET principle and was responsible for arbitrary measures. The remaining claims were rejected.

To decide the case, the tribunal had to undertake an extensive analysis of the concession agreement to which neither the claimant, nor the respondent were formal parties. ${ }^{229}$ The contractual provision on contract termination became one of the hot points of disagreement. The claimant argued that the concessioner was empowered to terminate the concession pursuant to its terms and that a contrary view would lead to an unjustified abuse of rights that would enable a party failing to perform its part of reciprocal obligations to benefit from its own failure. The province disagreed, arguing that it alone possessed the exclusive right to terminate the concession. According to the Province, the concessioner had to first apply to the Province for termination,

229 Ibid. para. 41. The concession was concluded between an Argentinian subsidiary of Azurix - Azurix Buenos Aires S.A., Administración General de Obras Sanitarias de la Provincia de Buenos Aires ('AGOSBA') - and the Province. 
and only if the Province did not agree, would the matter be referred to the court for termination.

Addressing the disagreement, the tribunal referred to the maxim exceptio non adimpleti contractus, presenting it as an expression of the principle of good faith:

The difficulty in interpreting the provisions of Article 14 harmoniously is compounded by Article 49-II of the Law which, as already noted, prescribes that termination "must be resolved by the Provincial Executive Authority with the intervention of овав." The Law does not distinguish between termination by the Grantor or the Concessionaire. It would seem appropriate that the Concession Agreement be interpreted consistently with the provisions of the Law. On the other hand, the Tribunal cannot ignore the practical result of this interpretation: if taken to the extreme, a concessionaire would be obliged to continue to provide the service indefinitely at the discretion of the government and its right to terminate the Concession Agreement would be deprived of any content. For this reason, the application of the maxim exceptio non adimpleti contractus provides a balance to the relationship between the government and the concessionaire. The Tribunal considers it immaterial whether ABA [Azurix Buenos Aires S.A.] raised this defense in its recourse to the Argentine courts. The Tribunal is assessing the conduct of the Respondent and its instrumentalities in the exercise of its public authority against the standards of protection of foreign investors agreed in the BIT, and the application of the maxim exceptio non adimpleti contractus has been raised by the Claimant in these proceedings. This exception is not unknown to Argentine law and to legal systems generally as it is a reflection of the principle of good faith. The Tribunal will take it into account when evaluating the actions of the Province under the standards of protection. ${ }^{230}$ [emphasis added]

In the subsequent reasoning, the tribunal was not very explicit as to the announced operation of exceptio non adimpleti contractus as part of the principle of good faith. Nor did the tribunal clarify the role of national law Argentinian law - applicable to the concession in relation to the operation of the principle. One can see nevertheless that the tribunal understood that it was the concessioner who possessed the right to terminate and exercised it properly. ${ }^{231}$ Zachary Douglas criticised the award precisely for the failure to

23 Ibid. para. 259-26o.

231 Ibid. para. 255-26o. 
apply national law, pointing to the inconsistency of the adopted principle of exceptio non adimpleti contractus with the concept of the administrative contract under French tradition that informed the Argentinian administrative law applicable to concessions. ${ }^{232}$ Argentina advanced the same argument in the annulment proceedings arguing that reliance on the principle was contrary to applicable national law and largely an unauthorised assumption of the function of ex aequo et bono. ${ }^{233}$ Azurix Corp. insisted that the respondent mischaracterised the reliance on the principle, its source and role in the tribunal's reasoning and highlighted the limited mandate of the annulment committee to review the award based on its substance. ${ }^{234}$ The annulment committee rejected the argument that the tribunal found the principle of exceptio non adimpleti contractus to be a part of Argentinian national law applicable to concessions. ${ }^{235}$ To the annulment committee, the tribunal's reasoning that the principle of exceptio non adimpleti contractus was 'not unknown in Argentine law' should not be perceived as a misconstruction of national law and in any event should not amount to the annullable failure. ${ }^{236}$

If one attempts to understand the precise operation of exceptio non adimpleti contractus in the tribunal's reasoning, through the perception of the annulment committee, one would rather see it not as a general principle of international law but as an emanation of the 'treaty standard' on fair and equitable treatment. ${ }^{237}$ A more detailed analysis of exceptio non adimpleti contractus reveals, however, that the principle was relied upon in a more sophisticated manner, first to offset constraints of the applicable national law and, second, to harmonise findings with other contractual provisions. The principle became an instrument to overcome unfair constructions that would deprive the concessioner of the right to terminate the contract because of the potential faults

232 See Zachary Douglas, The International Law of Investment Claims (Cambridge University Press 2009) 71-72, including fn 170 with reference to the works on administrative contracts.

233 Azurix Corp. v. The Argentine Republic (I), Decision on the Application for Annulment of the Argentine Republic dated 1 September 2009, para. 134 (d-j). It is interesting to see the parallel with the Sapphire case where the arbitrator, Judge Pierre Cavin, chose to emphasise that his reliance on general principles of law shall not be treated as a decision on $e x$ aequo et bono as he 'had no intention of deciding the case according to 'equity', like an 'amiable compositeur' - Sapphire International Petroleums Ltd. v. National Iranian Oil Company (1963) 35 ILR 135, 175 .

234 Azurix Corp. v. The Argentine Republic (I) Decision on the Application for Annulment of the Argentine Republic dated 1 September 20o9, para. 135 (h)-(j), (n), (o).

235 Ibid. para. $165^{-167 .}$

236 Ibid. para. 169 .

237 Ibid. para. 167. 
committed by the Province and would require the concessioner to continue to operate under the terms of the concession. One can recognise in this application of exceptio non adimpleti contractus a corrective function of international law operationalised via one of its sources - good faith as a general principle of law. $^{238}$

Justification behind the corrective function of international law requires substantial efforts. At the same time, it is the task of the tribunal to justify its findings in a transparent, comprehensive and methodologically sound manner. If one were to agree with this proposition, one would also recognise that the corrective function of good faith as a principle does not operate directly under contract construction, bypassing national law. Lack of a clear pronouncement in that regard led the respondent to believe that the tribunal justified the award on the basis of ex aequo et bono without being authorised by the parties. Azurix Corp. v. Argentina is therefore not a supporter of the primary or initial application of the general principles of law as a source of international law to contract interpretation, but can be a good case for illustrating an attempt to exercise the corrective function of international law.

To conclude an observation on the operation of good faith as a general principle in contract interpretation, one has to recognise that despite sharing similar ideas, good faith in international law, transnational law and national law do not operate as functional substitutes. Their content and mechanics of application are different. While any attempt to draw a clear line will be met with unavoidable criticism, a distinction, nevertheless, in the operation of good faith in interpretative rules/principles in international law, national laws and transnational sources, reflected in the summary below, is representative. Importantly, general principles of law while being almighty, do not solve all tasks and should not be used as a short way in reasoning bypassing essential elements, national law being part of it. A table summarising these observations is provided on the next page.

238 The corrective function of international law has been expressly recognised, albeit with some differences in accentuation, in scholarly works. See, for instance, W Michael Reisman, "The Regime for Lacunae in the ICSID Choice of Law Provision and the Question of Its Threshold' (2000) 15 (2) ICsID Review - Foreign Investment Law Journal 362-381; Prospeil Weil, 'The State, the Foreign Investor, and International Law: The No Longer Stormy Relationship of a Ménage À Trois (2000) 15 (2) ICSID Review - Foreign Investment Law Journal 401-416); Christoph Schreuer and others, The ICSID Convention: A Commentary (2nd edn, Cambridge University Press 2009) 620-627. On the relevance of national law to contract interpretation and on the corrective function of international law, see, for instance, the earlier cited Separate Opinion of Hersch Lauterpacht in the Certain Norwegian Loans (France v. Norway). 


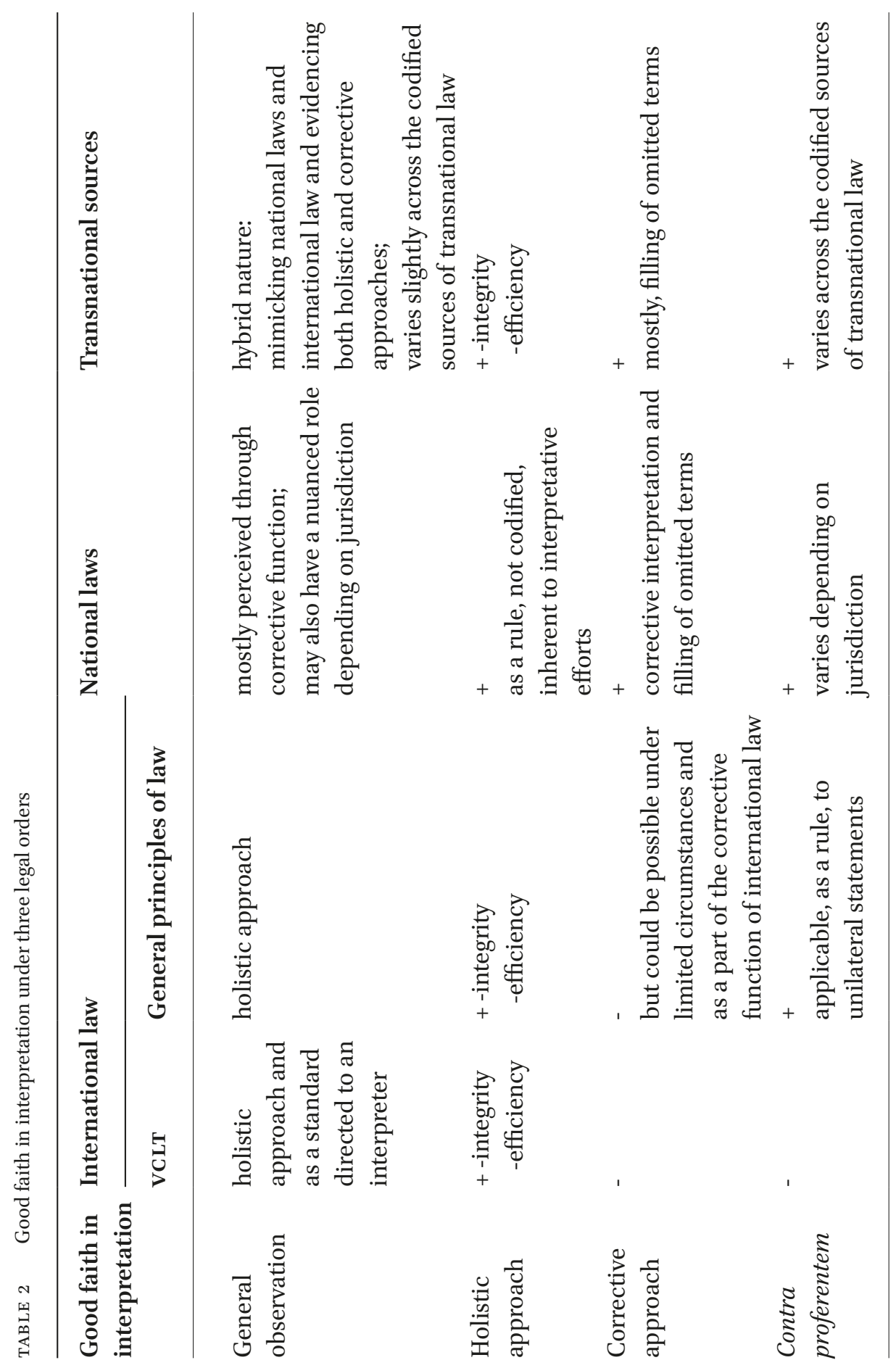


Contemporary misunderstanding about the role of the general principles of law in contract interpretation mostly echoes a number of widely discussed concession contract-based disputes. The disengagement from national laws, entire or partial, and reliance on general principles of law in these cases creates an impression of the inherent legitimacy proved by time that general principles of law possess in relation to contract interpretation. A more thorough analysis of these cases reveals in fact the limited role of the general principles as sources of international law in contract interpretation. History accordingly supplies further arguments.

Of the numerous concession disputes from 1930-1982, Lena Goldfields Company,${ }^{239}$ Abu Dhabi Oil Arbitration, ${ }^{240}$ Sapphire, ${ }^{241}$ Aramco, ${ }^{242}$ three Libyan Oil arbitrations, ${ }^{243}$ and Aminoil ${ }^{244}$ became the most widely known. ${ }^{245}$ These cases - all contract-based - evidence the augmented role of general principles of law either through the parties' express choice to have them act as applicable law or through the tribunals' application of them, or both. They triggered a theory of internationalisation and continue to nourish the development of its

239 Award is reproduced in Arthur Nussbaum, 'The Arbitration between the Lena Goldfields Ltd. and the Soviet Government' (1950) 36(1) Cornell Law Quarterly 31.

240 Petroleum Development Ltd $v$. Sheik of Abu Dhabi (Award 1951) 18 ILR 144; In the matter of an arbitration between Petroleum Development (Trucial Coast) Ltd. and the Sheikh of Abu Dhabi, Award of 28 August 1951 reproduced in (1952) 1 International \& Comparative Law Quarterly 247-261.

241 Sapphire International Petroleums Ltd. v. National Iranian Oil Company (NIOC) (Award, 1963) 35 ILR 136.

242 Saudi Arabia v. the Arabian American Oil Company (Aramco), (Award 1958) 27 ILR 117-229.

243 BP Exploration Co (Libya) v. Government of Libya (Award, 1973) 53 ILR 297; Texaco Overseas Petroleum Co v. Government of Libya (Award, 1977) 53 ILR 389; Libyan American Oil Co (LIAMCO) $v$. Government of Libya (Award, 1977) 62 ILR 141.

244 The Government of the State of Kuwait v. The American Independent Oil Company (AMINOIL) (Award, 1982) (1982) 21 ILM 976; F A Mann, 'The Aminoil Arbitration' (1984) 54 (1) British Yearbook of International Law, 213-221.

245 For some other similar cases of the period, including, for instance, arbitration Ruler of Qatar Case (Ruler of Qatar v. International Marine Oil Company Ltd. (Award 1953) (1953) 20 ILr 534, ICJ case Anglo-Iranian Oil Co (1952) ICJ, see Ivar Alvik, Contracting with Sovereignty: State Contracts and International Arbitration (Hart Publishing 2011) 33-37. For a list of other less known and less commented arbitration proceedings in the period, see also Jean-Flavien Lalive, 'Contracts between a State or a State Agency and a Foreign Company: Theory and Practice: Choice of Law in a New Arbitration Case' (1964) 13(3) International and Comparative Law Quarterly 987, 987-989. For significant arbitration cases on stabilisation clauses in the epoch preceding investment treaty arbitration, see also Peter D Cameron, 'Reflections on Sovereignty over Natural Resources and the Enforcement of Stabilization Clause' in Karl P Sauvant (ed), Yearbook on International Investment Law and Policy: 2011-2012 (Oxford University Press 2013) 311, 317, fn 22. 
various facets. What is more, the cases, while starting to engage with general principles of law as sources of international law, essentially discovered their transnational dimension and blurred an existing distinction between general principles of law as sources of international law and general principles of law as part of transnational law. The analysis of the potential interpretative role of general principles of law as sources of international law for contracts in investment treaty arbitration would not, accordingly, be complete if the momentum that general principles of law had gained in these concession arbitrations in the epoch preceding investment treaty arbitration had not been properly considered, and their associated myths dispelled. The remaining section, therefore, attempts to verify whether tribunals in these cases, in fact, relied upon general principles of law in their own name in order to ascertain the content of contractual provisions, and if so, whether said reliance stepped beyond a holistic dimension and the contra proferentem as identified by Kotuby and Sobota, to feature more specific rules.

Each case emerged in a rather peculiar historic and political conundrum, the elucidation of which is not necessary for the purpose of this discussion, although it is helpful for understanding the true motives that stand behind ideas of internationalisation. ${ }^{246}$ Many of these cases demonstrate an involvement of the same actors as counsel or arbitrators. ${ }^{247}$ Not all those that are mentioned will be elaborated upon here in detail. For a more complete overview, one is advised to refer to other sources. ${ }^{248}$ Here, the focus turns to tribunals' reasoning in relation to the ascertainment of the content of contractual provisions in concessions. At the same time, to give certain historic flavour and context to the analysis, some observations will be made on the nature of the concessions and the underlying circumstances behind the dispute.

Before turning to the cases, the theory of internationalisation needs to be introduced. Its discussion is also relevant for the whole chapter because of the illusion that the theory creates as to the capacity of international law to give

246 Among recent and informative insights, see, for instance, Katayoun Shafiee, 'Technopolitics of a Concessionary Contract: How International Law was Transformed by its Encounter with Anglo-Iranian Oil' (2018) 5o(4) International Journal of Middle East Studies 627, 627-648; see also Katayoun Shafiee, Machineries of Oil: An Infrastructural History of BP in Iran (The MIT Press 2018).

247 By way of illustration, counsel in Lena Goldfields Company, Vladimir Idelson, a lawyer from the Russian Empire, also drafted a concession agreement in Anglo-Iranian Oil Co see Norman Bentwich and K S C, 'Vladimir Idelson, Q. C.' (1955) 4(1) The International and Comparative Law Quarterly 27, 27-29.

248 See, for instance, Nico Schrijver, Sovereignty Over Natural Resources: Balancing Rights and Duties (Cambridge University Press 1997). 
substantive regulation to state contracts. The biggest and the most widespread mistake is to treat internationalisation as a single theory. Internationalisation is nothing but a range of various consolidated - and sometimes intersecting argumentative threads that various arbitration awards trigger, demonstrating the disengagement, partial or entire, of contracts from applicable national law. The arguments informing internationalisation may largely be divided into two groups: private and public. The private thread sees disengagement via methods based on party autonomy - arbitration clauses, choice-of-law provisions and stabilisation clauses; the public thread sees disengagement from national law via public international law, primarily provisions in IIAs, but also other fundamental provisions of international law, including general principles of law, that have an overriding correcting function. General principles of law play a role in both threads: in the private thread as part of the parties' express choice of applicable law and in the public thread as a constituent part of international law operating as an instrument of disengagement. Both threads were discernible in the inaugural part of the so-called theory in the 196os in some of the concession cases discussed here where in the absence of the IIAs, general principles of law served instrumentally for the disengagement of state contracts from national laws. ${ }^{249}$ With the emergence of investment treaty arbitration and proliferation of IIAs, the theory of internationalisation received more fuel in standards of investment protection in IIAs, ${ }^{250}$ and the reliance on the general principles of

249 For contemporaneous publications on internationalisation, see, for instance, Arnold McNair, 'The General Principles of Law Recognized by Civilized Nations ' (195) 33 British Yearbook of International Law 1; F A Mann, 'The Proper Law of Contracts Concluded by International Persons' (1959) 35 British Yearbook of International Law 34, 41; Jean-Flavien Lalive, 'Contracts between a State or a State Agency and a Foreign Company: Theory and Practice: Choice of Law in a New Arbitration Case' (1964) 13(3) International and Comparative Law Quarterly 987; on reconsidered role of general principles of law see A A Fatouros, 'International Law and Internationalized Contract' (1980) 74(1) American Journal of International Law 134, 134-141. For a contemporary analysis of the genesis of the period of internationalisation, see Ivar Alvik, Contracting with Sovereignty: State Contracts and International Arbitration (Harts Publishing 2011) 30-34. That the role of general principles in internationalisation is less visible in Alvik's analysis, is not a matter of disagreement, but rather of accentuation. Ivar Avik emphasises a particular role of arbitration in internationalisation. The interaction between arbitration, international law and national law in relation to contracts received further clarification in Alvik's subsequent publication - see Ivar Alvik, 'Arbitration in Long-Term International Petroleum Contracts: the 'Internationalization' of the Applicable Law' in Karl P Sauvant (ed), Yearbook on International Investment Law and Policy: 2011-2012 (Oxford University Press 2013) $388,404$.

250 On the role of the treaty provisions in internationalisation, see Jean Ho, State Responsibility for Breaches of Investment Contracts (Cambridge University Press 2018) 196-220. 
law as a source of international law for internationalisation became less visible. ${ }^{251}$ Responding to new trends, it became much rarer for general principles of law to be included in the choice-of-law provisions, whereas the role of national law became more apparent. ${ }^{252}$

The theory received fierce criticism because of its incapacity to fit comfortably, either in the doctrine of international law, or in the doctrinal constraints of national law. Analysing the method of internationalisation, commentators observe its self-referential character that justifies an external power of gravity for contracts in itself - primarily under the principle of pacta sunt servanda. ${ }^{253}$ Analysing the effect of internationalisation, commentators also

251 It seems that general principles of law gravitated towards a new dimension/transformed into a transnational legal order or lex mercatoria. This point receives thorough development in the recently finalised research project of Stephan Schill on lex mercatoria publica 'Transnational Private-Public Arbitration as Global Regulatory Governance: Charting and Codifying the Lex Mercatoria Publica'.

252 There is a certain deficit of empirical studies on the plurality of concession agreements, as noted by Peter D Cameron with reference to readily available model concession agreements - see Peter D Cameron, 'Reflections on Sovereignty over Natural Resources and the Enforcement of Stabilization Clauses' in Karl P Sauvant (ed), Yearbook on International Investment Law \& Policy: 2011-2012 (Oxford University Press 2013) 317, including fn 21. If one considers concession agreements invoked in investment treaty arbitration cases, one can see more often an express choice in favour of national law without any reference to general principles of law. See, for instance, Compañiá de Aguas del Aconquija S.A. and VivendiUniversal S.A.v.Argentine Republic, ICSID Case No. ARв $/ 97 / 3$, Award dated 20 August 2007, para. 4.5.1; Werner Schneider, acting in his capacity as insolvency administrator of Walter Bau Ag (In Liquidation) v. The Kingdom of Thailand, UNCITRAL, Award dated 1 July 20o9, para. 2.39; AWG Group Ltd. v. The Argentine Republic, UNCITRAL, Decision on Liability dated 30 July 2010, para. 98; EDF International S.A., SAUR International S.A. and León Participaciones Argentinas S.A. v. Argentine Republic, ICSID Case No. ARB/o3/23, Decision on Annulment dated 5 February 2016, para. 219; Urbaser S.A. and Consorcio de Aguas Bilbao Bizkaia, Bilbao Biskaia Ur Partzuergoa v. The Argentine Republic, ICsID Case No. АRв/07/26, Award dated 8 December 2016, para. 76, 78. At the same time a reference to international law can nevertheless be occasionally found - see, for instance, $C C L$ v. Republic of Kazakhstan, scc Case 122/2001, Jurisdictional Award dated 1 January 2003, where the choice of applicable law in addition to the host state law also included international law.

253 The origin of the criticism on the incapacity of international law to address contracts meaningfully can be found in early publications. For instance, A A Fatouros noted: 'Internationalization of the contract, moreover, resolves nothing by itself. It provides no generally accepted answers to the quest for the legal rules applicable. The only explicit rule the award [in Texaco Overseas Petroleum Co v. Government of Libya dated 19 January 1977] appears to deduce is that the principle pacta sunt servanda is applicable, which does not help much. Any law of contracts, national or international, is bound to start with this principle. But is cannot just stop there. In reality, the most important consequence of internationalization is implicit. In simplest terms, once a contract has moved to the international level, it cannot 
became sceptical regarding its capacity to meaningfully address all the possible issues that might arise in relation to a contract. The criticism culminated in the recognition that an attachment of contracts to international law does not solve any substantive problem as international law in its current stage of development is not apt to turn into a functional substitute for national law [an idea supported by this chapter, and which does not deny the potential capacity for international law to advance in that direction]. The analysis of the general principles recognised by international law demonstrates that while on abstract terms, general principles of law may be attractive in their capacity to substitute the national law, when analysed in concreto, however, their application is not capable of doing more than offer holistic principles of interpretation. If all the camouflage of attachment to international law is put aside, the only functional purpose of attachment of contracts to international law lies in the idea of pacta sunt servanda.

What remains to be done in the final part of this section, on the general principles of law and contract interpretation, is to verify the role of said general principles in the inaugural, first cases of internationalisation. Some of the most cited contract-based concession cases will be considered chronologically, by identifying the nature of the concessions, the character of the dispute, as well as the parties' choice and/or the tribunal's reliance on the general principles of law. While these cases have been addressed in a number of publications from various angles, they have not been considered from the perspective of contract interpretation, and the role of general principles of law in it.

lawfully be affected by unilateral national legal action. Since states cannot invoke their sovereignty to abrogate an international treaty, it is argued, neither can they do so to alter an internationalized contract.' - see A A Fatouros, 'International Law and Internationalized Contract' (1980) 74(1) American Journal of International Law 134, 136-137. For a more nuanced appreciation of internationalisation, essentially noting that internationalisation has nothing to do with the choice of substantive laws as such, but rather and exclusively with the binding effect of a contract, see Ivar Alvik, Contracting with Sovereignty: State Contracts and International Arbitration (Hart Publishing 2011) 56-58. For a comprehensive overview of the existent critique of internationalisation, including its impracticalities, see Jean Ho, State Responsibility for Breaches of Investment Contracts (Cambridge University Press 2018) 186-189. For a critique with a more severe tone engaging with the foundational basis of international law and national law, see Muthucumaraswamy Sornarajah, 'The Myth of International Contract Law' (1981) 15(3) Journal of World Trade 187, 187-217; see also Jean Ho reflecting and contextualising Sornarajah's critique - Jean Ho, 'Internationalisation and State Contracts: Are State Contracts the Future or the Past?' in Chin Leng Lim (ed), Alternative Visions of the International Law on Foreign Investment Essays in Honour of Muthucumaraswamy (Cambridge University Press 2016) 377-402. 
The dispute in Lena Goldfields Company arose in relation to the termination of the concession agreement for exploration, mining and transportation of gold and other minerals in the territory of the Soviet Union concluded between the company, registered in the UK, and the Soviet Government. Concluded in 1925, the contract was revoked in 1929 under the circumstances of the changed state policy. The liberalisation of the economic thaw associated with the new economic policy, or NEP, was over. Instead the economy became centralised with five-year plans and supremacy of the state property and management in economic life. Lena Goldfields initiated arbitration against the State on the basis of the arbitration agreement contained in the concession claiming damages that arose because of termination of the concession. The respondent appointed an arbitrator, but thereafter failed to take part in the process. The arbitrator appointed by the respondent also failed to participate in the decision-making process, and the award was signed by the two other arbitrators: an arbitrator appointed by the claimant and by the chairman. According to Ivar Alvik, the ultimate award against the Soviet Union amounted to a considerable amount of about 500 million pounds, when adjusted to $2005 .{ }^{254}$ The case was subsequently settled, whereas difficulties with performance of the settlement received express regulation in the inter-state treaty between the UK and the Soviet Union in 1968.255

Section 89 of the concession specified general principles of laws as being applicable to the contract and its interpretation: 'the parties base their relations with regard to this agreement on the principle of good will and good faith, as well as reasonable interpretation of the terms of the agreement. ${ }^{256}$ Exploring this choice further, counsel for the claimant emphasised in the course of the proceedings that 'many of the terms of the contract contemplated the application of international rather than merely national principles of law.'257 The tribunal shared this view, and essentially based its decision on principles of unjust enrichment. ${ }^{258}$ At the same time, general principles of law did not inform the contract's interpretation. Rather than relying on any external source of

254 Ivar Alvik, Contracting with Sovereignty: State Contracts and International Arbitration (Hart Publishing 2011) 31.

255 Andrea Ernst, 'Lena Goldfields Arbitration', Max Planck Encyclopedia of Public International Law <https://opil.ouplaw.com/view/10.1093/law:epil/978019923169o/law978019923169o-e158?prd=EPIL $>$ updated August 2014, accessed 25 June 2021.

256 The award is reproduced in and cited here from Arthur Nussbaum, 'The Arbitration between Lena Goldfields Ltd. and the Soviet Government' (1950-1951) 36 Cornell Law Quarterly 31, 42, para. 6.

257 Ibid. para. 22.

258 Ibid. para. 25 . 
justification, the tribunal approached the contractual provisions in complete isolation from any legal order.

In Abu Dhabi Oil Arbitration, a dispute arose in relation to a concession concluded in 1939 between Petroleum Development Ltd., a company registered in the UK, and the Sheik of Abu Dhabi over the exclusive rights to drill and extract mineral oil in Abu Dhabi for 75 years. ${ }^{259}$ The dispute arose because the Sheik transferred the rights to explore oil in the territories outside of the territorial waters of Abu Dhabi to an American company. Petroleum Development Ltd. perceived this as a violation of the scope of the own concession agreement with the Sheik. The arbitrator (an umpire appointed because the two other arbitrators disagreed) had to decide on declaratory relief - whether a new contract violated the concession agreement of 1939. The terms of the concession contract appeared critical. In the concession, the parties agreed 'to execute this Agreement in a spirit of good intentions and integrity, and to interpret it in a reasonable manner. ${ }^{260}$ The award is notorious for the rather sharp comments of the umpire in relation to the existence and capacity of applicable Sharia law to address 'the construction of modern commercial instruments' 261 and his decision to base the award on 'the good sense and common practice of the generality of civilized nations - a sort of modern law of nature.'.62 The arbitrator treated the choice of law as repelling the notion of national law. At the same time his sharpness in comments on Sharia law did not translate into a negative decision for the respondent, and some of the claimant's requests were subsequently denied. General principles on their proper name did not technically inform contract interpretation. The contract was taken in isolation with exception to the key disagreement being the territorial scope of the concession - the concept of 'territorial waters' - that the arbitrator interpreted, in light of the position under international law. In other words, while the general principles of laws did not inform interpretation, the concept of international law became a

259 Petroleum Development Ltd v. Sheik of Abu Dhabi (Award 1951) 18 ILR 144; Arbitration between Petroleum Development (Trucial Coast) Ltd. and the Sheikh of Abu Dhabi, (1953) 47(1) The American Journal of International Law 156, 156-159; Asquith of Bishopstone, 'Award of Lord Asquith of Bishopstone' (1952) 1(2) International and Comparative Law Quarterly 247, 247-261; Rudolf Dolzer, 'Abu Dhabi Oil Arbitration', Max Planck Encyclopedia of Public International Law <http://opil.ouplaw.com/view/10.1093/law:epil/ 978019923169o/law-978019923169o-e84> updated December 2006, accessed 25 June 2021..

26o Petroleum Development Ltdv. Sheik of Abu Dhabi (Award 1951) - see Asquith of Bishopstone, 'Award of Lord Asquith of Bishopstone' (1952) 1(2) International and Comparative Law Quarterly 247, 249-250.

261 Ibid. 251.

262 Ibid. 
relevant background against which the content of the contractual provisions was construed.

In the Sapphire case, ${ }^{263}$ a joint venture to expand the production and exportation of Iranian oil was concluded between the National Iranian Oil Company (NIOC) and Sapphire Petroleum Ltd. (Sapphire), a Canadian company. The parties set up the joint Iranian Canada Oil Company to carry out the contract. Sapphire International, to which Sapphire Petroleum Ltd. assigned its rights under the contract, claimed reimbursement of the expenses from the NIOC, which Sapphire International incurred in the concession area. The NIOC refused to cover these expenses, arguing that the works carried out by Sapphire had not been agreed to with the NIOC, ultimately repudiating the contract. The contract did not contain any express choice-of-law provision. From the choice of arbitration, a reference to good faith and from no choice of applicable law, the tribunal implied a negative choice, excluding the application of the most relevant Iranian law, deciding that general principles of law were relevant. ${ }^{264}$ In the absence of any express tie of good faith to national law in the contractual clause, the tribunal connected it to the general principle of law as a source of international law:

On the other hand a reference to rules of good faith, together with the absence of any reference to a national law, leads the judge to determine, according to the spirit of the agreement, what meaning he can reasonably give to a provision of the agreement which is in dispute. It is therefore perfectly legitimate to find in such a clause evidence of the intention of the parties not to apply the strict rules of a particular system but rather to rely upon the rules of law, based upon reason, which are common to civilised nations. These rules are enshrined in article 38 of the Statute of the International Court of Justice as a source of law, and numerous decisions of international tribunals have made use of them and clarified them. Their application is particularly justified in the present contract, which was concluded between a state organ and a foreign company,

263 Sapphire International Petroleums Ltd. v. National Iranian Oil Company (NIOC) (Award, 1963) 35 ILR 136; Martins Paparinskis, 'Sapphire Arbitration', Max Planck Encyclopedia of Public International Law <https://opil.ouplaw.com/view/10.1093/law:epil/978o19923169o/ law-978019923169o-e205> updated April 2010, accessed 25 June 2021.

264 Jean-Flavien Lalive, 'Contracts between a State or a State Agency and a Foreign Company: Theory and Practice: Choice of Law in a New Arbitration Case' (1964) 13(3) The International and Comparative Law Quarterly 987, 1012. One can see a similar line of argumentation on negative choices of law in the contemporary treaty-based case Lemire v. Ukraine (II). 
and depends upon public law in certain of its aspects; it has therefore a quasi-international character which releases it from the sovereignty of particular legal system and it differs fundamentally from an ordinary commercial contract. It should be mentioned that the question of the law applicable did not altogether escape the draftsman of the agreementsee letter $(\mathrm{d})$ below; and the absence of any reference to a national law can only confirm this conclusion. ${ }^{265}$

The award became exemplary of the extensive and detailed comparative efforts to distil common principles in various national laws in relation to the very specific and rather complex interpretative problem of synallagmatic contracts contracts with interdependent mutual/reciprocal undertakings between the parties. After demonstrating that the principle of reciprocal interdependent undertakings finds its place in the laws of various jurisdictions, the tribunal chose to emphasise its common sense and fairness:

These principles are no more than the expression of a logical requirement, which explains why they are generally recognized. However different the judicial techniques employed may be, however divergent may be the theoretical explanations given by doctrine, one point is certain: this principle is explained by the interdependence of the obligations contained in the same contract. It would be illogical and contrary to the most elementary notions of equity if one party could obtain satisfaction while the other suffered a loss. Whether the notion of the reciprocal effect of obligations, of the equal value of obligations, or of the implied condition is relied on, it is impossible to escape the essential and elementary conclusion that one of the parties must not benefit from the performance of the contract by his partner while evading his own obligations. ${ }^{266}$

The principle of interdependent undertakings assisted in finding the breach of the concession, but at the same time, it had little impact on contract interpretation as such. The tribunal construed the contract rather on its own terms, taken as a whole and without finding external justification in international law.

265 Ibid. 1013.

266 Ibid. 1016-1017 (cited on the basis of award extracts published as an annex to the article of Jean-Flavien Lalive). 
In the Saudi Arabia v. Aramco case, ${ }^{267}$ a dispute arose between Saudi Arabia and the Arab American Oil Company (Aramco) in relation to interpretation of the concession agreement between them concluded in 1930 in light of the exclusive general rights of transportation of oil being subsequently granted by Saudi Arabia to another company, the Saudi Arabian Maritime Tankers Company (Satco). Saudi Arabia attempted to compel Aramco to transport oil using Satco tankers whereas Aramco objected, justifying its decision by pointing to undertakings of Saudi Arabia under their concession agreement. The key interpretative question that arose before the tribunal related to ascertaining whether Aramco acquired a right of transportation under the concession with Saudi Arabia. While the tribunal made it explicit that public international law did not govern the concession, it recognised that international law was relevant to certain aspects of the dispute that could not be governed by national laws, including state responsibility. In what relates to contract interpretation, the tribunal predominantly exercised a textual approach as 'the supreme authority of the text which was the object of the Parties' agreement must always be upheld', or in the words of one of the counsel in the case, Stephen Schwebel, 'the written word came first'. 268 The tribunal refused to rely on contra proferentem or to exercise a restrictive interpretation, although it accepted the existence of a principle of restrictive interpretation: 'The principle of restrictive interpretation of the contractual obligations of a government toward a private individual is not a cardinal rule of legal interpretation. It is only one rule among many others. To resort to restrictive interpretation, it is not enough to contend that the text of a contract is ambiguous or incomplete. That must be established before one can have recourse to restrictive interpretation. But in this case, the Government had failed to prove that the meaning of the Concession's text was doubtful.'269

The concessions in three Libyan oil cases, involving British Petroleum (вР), ${ }^{270}$ the Texaco Overseas Petroleum Company (торсо),,271 and the Libyan American Oil Company (LIAMCO), ${ }^{272}$ were all based on the same model which provided that concessions 'shall be governed by and interpreted in accordance

\footnotetext{
267 Stephen Schwebel, "The Kingdom of Saudi Arabia and Aramco Arbitrate the Onassis agreement' (2010) 3(3) The Journal of World Energy Law \& Business 245, 245-256.

268 Ibid. 251.

269 Ibid. 253.

270 BP Exploration Co (Libya) v. Government of Libya (Award, 1973) 53 ILR 297.

271 Texaco Overseas Petroleum Co v. Government of Libya (Award, 1977) 53 ILR 389; Julien Cantegreil, 'The Audacity of the Texaco/Calasiatic Award: René-Jean Dupuy and the Internationalization of Foreign Investment Law' (2011) 22 (2) The European Journal of International Law 441.

272 Libyan American Oil Co (LIAMCO) v. Government of Libya (Award, 1977) 62 ILR 141.
} 
with the principles of the law of Liby a common to the principles of international law and in the absence of such common principles then by and in accordance with the general principles of law, including such of those principles as may have been applied by international tribunals'. The reasoning in each of the awards differed. In $B P$ v. Libya, in deciding the dispute, the sole arbitrator, Gunnar Lagergren, ${ }^{273}$ relied on general principles of law without connecting them to international law. ${ }^{274}$ In Texaco v. Libya, René-Jean Dupuy attempted to navigate between recognising the role of national law as the 'proper' law of a contract and international law as 'the legal order from which the binding nature of the contract stems. ${ }^{275}$ In LIAMCO v. Libya, Dr Mahmassani found that Libyan law applied to the extent common to international law and general principles of law, 276 an approach marked by Ivar Alvik as a 'conditioned version of national law' ${ }^{277}$ In any case, attributing somewhat different functions to general principles in overall reasoning over the causae, in none of the Libyan oil cases did the tribunal justify their interpretation of concession agreements by relying on certain general principles of law in their own name. Rather, concessions were construed in isolation, without any external justification.

In the Aminoil case, ${ }^{278}$ a dispute arose in relation to the termination/ nationalisation of the 6o-year concession agreement concluded between Aminoil, an American company, and Kuwait in 1949. The tribunal found the nationalisation to be lawful and not in violation of the stabilisation clause, at the same time awarding compensation to Aminoil. The parties gave leeway to the tribunal in determining applicable law, having agreed that: 'The law governing the substantive issues between the Parties shall be determined by the Tribunal, having regard to the quality of the Parties, the transnational character of their relations and the principles of law and practice prevailing in the modern world'. ${ }^{279}$ The tribunal understood the provision as welcoming the application of Kuwaiti law, together with due consideration of international law, including the general principles of law. ${ }^{280}$ The tribunal found it essential to underline

273 Gunnar Lagergren subsequently became a President of the Iran-USA Claims Tribunal where finding principles of law common to the law of the USA and Iran frequently became the dominant approach of justification in relation to contract-based cases.

274 BP Exploration Co (Libya) v. Government of Libya (Award, 1973) 53 ILR 297, 327-9.

275 Texaco Overseas Petroleum Co v. Government of Libya (Award, 1977) 53 ILR 389, 443.

276 Libyan American Oil Co (LIAMCO) v. Government of Libya (Award, 1977) 62 ILR 141, 175-6.

277 Ivar Alvik, Contracting with Sovereignty: State Contracts and International Arbitration (Hart Publishing) 39 .

278 Aminoil v. Kuwait (Award, 1982) (1982) 21 ILm 976; F. A. Mann, 'The Aminoil Arbitration' (1984) 54(1) British Yearbook of International Law 213, 213-221.

279 Ibid. para. 8.

28 o Ibid. para. 6-10. 
that international law was essentially part of Kuwaiti law. ${ }^{281}$ Interpretation of the stabilisation clause became critical and the tribunal found that the provision did not possess absolute power in the sense of prohibiting nationalisation per se, but rather in prohibiting a confiscatory nationalisation without due compensation. ${ }^{282}$ Rather than justifying the limited interpretation of the stabilisation agreement by some external principles, the tribunal referred to the inner content of the contractual relations that had undergone substantial transformations with time: 'It is not a case of a change involving a departure from a contract, but of a change in the nature of the contract itself, brought about by time, in the acquiescence or conduct of the Parties. ${ }^{283}$ Above all, general principles of laws were not expressly relied upon for construing the contractual provisions.

For these historic arbitration cases to primarily empower the general principles of law meant to switch to another centre of gravity for contracts that would provide external justifications. While expressly located in general principles of law as a source of international law, that centre of gravity in fact stepped outside international law stricto senso. In addition to internationalisation, the analysed cases may be viewed as precursors to the emergence of the transnational legal order. ${ }^{284}$ In any case, be it international law or emerging transnational law,

281 Ibid. para. 10.

282 Ibid para. 88-102.

283 Ibid para. 101.

284 For instance, the 1957 work of Arnold McNair, largely perceived by contemporary arbitrators as a proxy for the application of the general principles of law ought to be understood with more nuance and care. Rather than perceiving general principles of law as sources of international law in their operation in relation to private parties, McNair saw that the legal system, applicable to economic development contracts, was of a transnational character: '... it is submitted that the legal system appropriate to the type of contract under consideration is not public international law but shares with public international law a common source of recruitment and inspiration, namely, 'the general principles of law recognized by civilized nations' - Arnold McNair, 'The General Principle of Law Recognized by Civilized Nations' (1958) 33 British Yearbook of International Law 1, 6. Further signs of transnational legal order in the reliance on general principles of law at the time and in relation to the concession arbitration can be found in the works of J.-F. Lalive, cited above, and who observed: 'The second problem, of a less conspicuous and more subtle nature, is that of the legal system, or systems, in which the general principles may be incorporated and of which they form part. Are they necessarily part of international law only, and is it not preferable to envisage a third and new system, called Transnational Law? The great majority of lawyers drafting contracts, judges, arbitrators and writers have taken for granted that the "general principles" belong to international law and are to be equiparated to "general principles of international law.' - Jean-Flavien Lalive, 'Contracts between a State or a State Agency and a Foreign Company: Theory and Practice: Choice of Law in a New Arbitration Case' (1964) 13(3) The International and Comparative Law Quarterly 987, 987, 100o. See 
the functional operation of this new centre of gravity was limited to pacta sunt servanda. For contract interpretation, that meant very little. Out of the mentioned cases, only with Aminoil did the tribunal rely on efficiency in addressing the concession. However, the justification for the approach, based on efficiency, pointed rather to transnational rather than international law. It is accordingly no surprise that the award is featured on the 'Creeping Codification' project through the TransLex Principles at www.trans-lex.org operated by the Center for Transnational Law (CENTRAL) at Cologne University, Germany. ${ }^{285}$ In other words, a recognition of an international/transnational component in applicable substantive regulation in the early concession cases does not supply any concrete instrument for contract interpretation, beyond discussed dimensions of integrity and efficiency that largely correspond to holistic principles of interpretation and common sense.

Thus, general principles of law as sources of international law, while capable of providing certain answers to interpretative problems surrounding contracts (if one accepts their extension to private law instruments in the first place), have limited instrumentality. Currently, the existent practice of international courts and tribunals, as well as historic cases, that extensively relied on general principles, does not permit one to see that the principles were applied to distil either through interpretation or through lacunae-filling function distinct rules in international law for contract interpretation. When analysed as substantive regulatory principles or norms, general principles also show that they reach contractual material at a very high and abstract level. Logical and axiological premises of good faith undergo denationalisation and reduction to the standard of reasonableness. This level may appear to achieve justice and is no doubt important, but it does not constitute a sufficient regulation for contract interpretation. The resulting instrumentality that one may potentially distil from

also, A A Fatouros, Government Guarantees to Foreign Investors (Columbia University Press 1962), 284-285. Undoubtedly, the revolutionary work of Philip Jessup on transnational law did not remain unnoticed during the period - Philip Jessup, Transnational Law (New Haven: Yale University Press, 1956). On the role of international law in the emergence and flourishing of transnational law pointing to the same period, see also Gregory C Shaffer and Carlos Coye, 'From International Law to Jessup's Transnational Law, from Transnational Law to Transnational Legal Orders' (2017) 2 UC Irvine School of Law Research Paper <https://ssrn.com/abstract=2895159> accessed 25 June 2021.

285 Kuwait v. The American Independent Oil Company (AMINOIL) available at <https://www. trans-lex.org/2619oo>, accessed 25 June 2021. See also, Klaus Peter Berger, 'Creeping Codification of the New Lex Mercatoria: The TransLex Principles at www.trans-lex.org', (Kluwer Arbitration Blog, 20 January 2010) <http://arbitrationblog.kluwerarbitration. $\mathrm{com} / 2010 / 01 / 20 /$ creeping-codification-of-the-new-lex-mercatoria-the-translex-princip les-at-www-trans-lex-org>, accessed 25 June 2021. 
the general principles of law as a source of international law does not step beyond the two holistic principles of interpretation - integrity and efficiency, principles that hardly require external justification.

Furthermore, as a more encompassing overview, even if one agrees that international law governs contracts, the rules available to international law, international treaties, customary international law, and the general principles of law, offer neither a thorough regulated background law, nor a tuned apparatus capable of independently addressing all the possible nuances of contract interpretation.

\subsection{Subsidiary Means for Determining the Content of International Law}

Having identified the somewhat limited capacity of two sources of international law ${ }^{286}$ to address contract interpretation, it may be moot to attempt to look at judgments and the 'teachings of the most highly qualified publicists' independently, as a secondary means to determine the content of international law via the understanding of Article 38 of the ICJ Statute. Some of the judgments and scholarly publications have already been considered in previous subsections that address treaties, customary international law and the general principles of law. Nevertheless, for the sake of a complete overview of the capacity of international law, in its present shape and form, to address contract interpretation, we will briefly turn to the judgments and 'teachings of the most highly qualified publicists' in this conclusive section.

Without engaging extensively in the complexity of attributing a status of a subsidiary source, as understood under Article 38 of the ICJ Statute, to judgments and scholarly works, a significant task in itself,, 287 one might attempt

286 In previous sections, I identified rules for interpretation of contracts in the CISG. I also considered the limited role of the general principles of law as a source of international law for contract interpretation.

287 It is commonly accepted that not every judgment and not every publication is sufficient to reach the level of a secondary source as understood under article 38 of the ICJ Statute - see, for instance, Alain Pellet, 'Article 38' in Andreas Zimmermann and others (eds), The Statute of the International Court of Justice: A Commentary (2nd edn, Oxford University Press 2012) 731-870; Sir Michael Wood, 'Teachings of the Most Highly Qualified Publicists' (Art. 38 (1) ICJ Statute), Max Planck Encyclopedia of Public International Law $<$ https://opil.ouplaw.com/view/10.1093/law:epil/978o19923169o/law-978o19923169oe1480> updated March 2017, accessed 25 June 2021; Michael Peil, 'Scholarly Writings as a Source of Law: A Survey of the Use of Doctrine by the International Court of Justice' 
to limit one's investigation to prima facie authoritative sources. For jurisprudence in public international law engaged in the ascertainment of the content of contractual provisions, the World Court will be prioritised. ${ }^{288}$ For scholarly works and in the absence of institutional works on contract interpretation in the context of public international law, ${ }^{289}$ it is important to primarily assess publications by regularly cited individual scholars. In other words, while authority remains important for this inquiry, it is not an independent focus in itself, and the primary emphasis for this section is rather on the availability

(2012) 3(1) Cambridge Journal of International and Comparative Law 136, 136-161; Christopher Greenwood, 'Sources of International Law: An Introduction' <http://legal. un.org/avl/pdf/ls/greenwood_outline.pdf> accessed 25 June 2021; Alain Pellet, 'Gaetano Morelli Lectures: Decisions of the ICJ as Sources of International Law?' (International and European Papers Publishing 2018) <http://crde.unitelmasapienza.it/sites/default/files/ GMLS\%20-\%2oDecisions\%2oof\%2othe\%2oICJ\%2oas\%2oSources\%2oof\%2oInternatio nal\%2OLaw\%20\%282018\%29.pdf> accessed 25 June 2021. Different views exist on the precise significance of judgments and publications. A textual reading of article 38 of the ICJ Statute ensures a wide consensus that judgments and publications are considered to be subsidiary sources for identification. At the same time, there is also an accentuating view on the growing significance of these sources in the process of deformalising international law - Jean d'Aspremont, 'The Politics of Deformalization in International Law' (2011) 3(2) Goettingen Journal of International Law 503, 507. Furthermore, the work of Jean Ho identifies arbitral awards as a primary source for the rules on state responsibility for the breach of investment contracts - see, for instance, Jean Ho, 'Arbitral Awards and the Generation of International Law' in Jean Ho, State Responsibility for Breaches of Investment Contracts (Cambridge University Press 2018) 61-89.

288 On the role of ICJ jurisprudence in international law, see also Christian Tams, 'Gaetano Morelli Lectures Series: The Development of International Law by the ICJ' (International and European Papers Publishing 2018) <http://crde.unitelmasapienza.it/sites/default/ files/GMLS\%20-\%2oDecisions\%2oof\%2othe\%2oICJ\%2oas\%2oSources\%2oof\%2oIn ternational\%20Law\%20\%282018\%29.pdf> accessed 25 June 2021; Robert Kolb 'The Jurisprudence of the ICJ' in Robert Kolb, The Elgar Companion to the International Court of Justice (Edward Elgar Publishing 2014) 375-403.

289 Institutional works, for instance, of the UN International Law Commission or International Law Association, gain high authority and credibility. None can be identified, though, in relation to contract interpretation for those contracts that, for instance, trigger state responsibility and appear in an adjudicative context of public international law. For a historic overview of state and private codification in relation to state responsibility for contractual breaches and controversy behind the topic that led to its exclusion from the work of the International Law Commission on state responsibility, see Jean Ho, State Responsibility for Breaches of Investment Contracts (Cambridge University Press 2018) 4658 . Yet, no specific provisions on contract interpretation, attributable to international law, were articulated at that time when the issue was not excluded from intense consideration. To the contrary, some of the discussed drafts in the period expressly provided for the role of the national law applicable to a contract in deciding on arbitrariness and wrongfulness of the states conduct - see Article 12 of the Harvard Draft Convention 1961. 
of an indication of the rule of international law among judgments and scholarly works.

Given the limited result, which has already been revealed in relation to international treaties, customary international law and the general principles of law, there is a high probability that no indication of rules of international law for contract interpretation beyond what has already been spotted, can be identified. Therefore, accordingly, authoritative negative proclamations, i.e. on the role of national law instead of the role of international law for contract interpretation, will also be considered in this concluding section.

\subsubsection{Judicial Practice}

Even though contract interpretation is not a routine type of legal reasoning for the World Court, at least six cases - two advisory and four contentious evidence the Court's various attempts to ascertain the content of contractual provisions for the various purposes of its mandate. ${ }^{290}$ In Settlers of German Origin in Poland, ${ }^{291}$ the PCIJ had to give an advisory opinion on the legal issue in a dispute on the application of the League of Nations. The PCIJ examined contracts, under which former German nationals who were domiciled in Polish territory previously belonging to Germany, and who had acquired Polish nationality, were occupying their holdings and which Poland planned to cancel. In another advisory opinion on the application of UNESCO in Judgments of the Administrative Tribunal of the International Labour Organization upon complaints made against the United Nations Educational, Scientific and Cultural Organization, ${ }^{292}$ the ICJ analysed, among other things, employment contracts concluded between individuals and UNESCO. The remaining four contentious cases primarily related to the rights of aliens protected under international law. In the contentious Serbian Loans ${ }^{293}$ and Brazilian Loans, ${ }^{294}$ the focus turned to

290 These cases are also addressed in Chapter 4 to demonstrate the power of treaty-based tribunals to interpret contracts.

291 Settlers of German Origin in Poland, (1923) Advisory Opinion of 10 September 1923 [1923] PCIJ Report Series B, No. 6; Gudmundur Alfredsson, 'Cases Concerning the German Minorities in Poland', Max Planck Encyclopedia of Public International Law <https://opil. ouplaw.com/view/10.1093/law:epil/978019923169o/law-978o19923169o-e138> updated April 2010, accessed 25 June 2021.

292 Judgments of the Administrative Tribunal of the International Labour Organization upon complaints made against the United Nations Educational, Scientific and Cultural Organization (1956) Advisory Opinion [1956] ICJ Rep. 77.

293 Payment of Various Serbian Loans Issued in France (France v. Yugoslavia) (Judgment of 12 July 1929) PCIJ Series A No. 20.

294 Payment in Gold of Brazilian Federal Loans Contracted in France (France v. Brazil) (Judgment of 12 July 1929) (1929) PCIJ Series A No 21. 
loan agreements relating to the issue of bonds. ${ }^{295}$ In Lighthouses, ${ }^{296}$ the PCIJ had to consider concession contracts between a French firm and the Ottoman government concerning certain lighthouses situated in the territories of Crete and Samos. In Mavrommatis, ${ }^{297}$ the PCIJ addressed concessions for the construction and working of an electric tramway system, for the supply of electricity and power and of drinking water in Jerusalem and Jaffa. The extent of the analysis varied. Save for Serbian and Brazilian Loans, other cases demonstrate rather perfunctory contract interpretation.

None of the cases are recent. The earliest took place in 1923, and the latest in 1956. A considerable gap emerged since the last attempt of the Court to construe the content of contractual provisions. The timing brings a specific historical flavour of espousal for these cases. In Mavrommatis, Greece claimed that the UK, having assumed control over the territory of Palestine, failed to recognise the full extent of the rights which Mavrommatis received under concessions concluded with Ottoman authorities in relation to work in Palestine prior to when the UK assumed control. In Lighthouses, France espoused the claim of its nationals in relation to Greece, to which lighthouses (the object of the concessions) were assigned after being taken from the Ottoman government following the Balkan Wars. Both the Serbian Loans and the Brazilian Loans were taken out by France in favour of its nationals, but unlike in the above-mentioned cases, a special agreement between the two states (in the case of Serbian Loans - the Kingdom of the Serbs, Croats and Slovenes and France, and in the case of Brazilian Loans, Brazil and France) empowered the PCIJ to express its opinion on matters tied to the interpretation of currency clauses in loan agreements. 298

295 Given the contemporary distinctions between syndicated loans and bonds, Thomas Wälde suggested that the case should have been named in modern terms, as the Serbian Bonds Case - Thomas Wälde, 'The Serbian Loans Case - a Precedent for Investment Treaty Protection of Foreign Debt?' in Todd Weiler (ed), International Investment Law and Arbitration: Leading Cases from the ICSID, NAFTA, Bilateral Treaties and Customary International Law (Cameron 2005) 388.

296 Lighthouses Case between France and Greece (France v. Greece) (Judgment of 17 March 1934) (1934) PCIJ Series A/B, No. 62.

297 Mavrommatis Jerusalem Concessions (Greece $v$. UK) (26 March 1925) PCIJ, Series A, No. 5; for contemporaneous analysis, see Edwin M Borchard, 'The Mavrommatis Concessions Cases' (1925) 19(4) The American Journal of International Law 728, 728-738. For an interesting modern perspective on the case, see Rosalyn Higgins, 'Natural Resources in the Case Law of the International Court' in Alan Boyle and David Freestone (eds), International Law and Sustainable Development: Past Achievements and Future Challenges, Essays in Honour of Patricia Birnie (Oxford University Press 1998) 87-111.

298 The PCIJ explained its mandate to interpret contracts in Serbian Loans as follows: 'It must however be considered that the Court has been made cognizant of this case not by unilateral 
After a thorough analysis, none of the six cases have become indicative of the rules of international law on contract interpretation. Even though the World Court exercised a rather independent, reasonable construction of contractual terms, national law was not entirely ignored. The Court relied on national law to a certain extent, either for contract construction (Settlers of German Origin in Poland, Serbian Loans, Brazilian Loans) or findings on contract validity (Lighthouses). In the Court's independent construction and in the primacy of the contractual text, some of the authors see the World Court as being equipped by the general principles of law - good faith and pacta sunt servanda. ${ }^{299}$ While it is quite possible that the considerations of these general principles of law became decisive, the Court however has not explicitly clarified the role of the general principle of law, if any, for contract construction. Furthermore, neither of the decisions cited above have subsequently been used as authority for suggesting that general principles of law guide contract interpretation in the practice of investment treaty arbitration. ${ }^{300}$ Equally, at least three cases of Serbian Loans, Brazilian Loans and the Case of Certain Norwegian Loans (France v. Norway) ${ }^{301}$ continue to frequently be retained for their symbolic recognition of the role of national law, whereas the rather specific context of those clarifications is often overlooked or omitted. ${ }^{302}$

application but by a Special Agreement. The two States signing the Special Agreement approach the Court as they would an arbitrator and they ask it to decide - as they might ask legal experts - upon a question of the interpretation of contracts in regard to which they disagree.' - see Payment of Various Serbian Loans Issued in France (France v. Yugoslavia) (Judgment of 12 July 1929) PCIJ Series A No. 20.

299 Thomas Wälde, "The Serbian Loans Case - a Precedent for Investment Treaty Protection of Foreign Debt?' in Todd Weiler (ed), International Investment Law and Arbitration: Leading Cases from the ICSID, NAFTA, Bilateral Treaties and Customary International Law (Cameron 2005) 395-398.

300 Jurisprudence of the PCIJ and the ICJ has not informed tribunals' interpretative efforts in relation to contracts. For the role of ICJ jurisprudence on other issues in investment treaty arbitration, see Alain Pellet, 'The Case Law of the ICJ in Investment Arbitration' (2013) 28(2) ICSID Review 223, 223-224.

301 In 1957, in Case of Certain Norwegian Loans (France v. Norway), the ICJ was close to interpreting a 'golden clause' in loans, similarly to what the PCIJ did in the Serbian and Brazilian Loans cases. The ICJ, however, declined its jurisdiction and this closed any investigation into the content of the contractual provisions of the loans. - Case of Certain Norwegian Loans (France v. Norway) (Preliminary Objections) [1957] ICJ Rep 9.

302 See, for instance, Hans van Loon and Stéphanie De Dycker, 'The Role of the International Court of Justice in the Development of Private International Law' in Randall Lesaffer and others (eds), Mededelingen van de Koninklijke Nederlandse Vereniging voor Internationaal Recht - Nr. 140 - One Century Peace Palace, from Past to Present (T.M.C. Asser Press 2013). 
All the cases discussed by the World Court belong to the epoch preceding investment treaty arbitration. Should no investment treaty arbitration have emerged enabling an individual to arbitrate with the state in relation to investment contracts, one could reasonably have expected more cases on espousal where the World Court would be required to ascertain the content of contractual provisions. As a result, Wilfred Jenks' contemporaneous observation on what has been deemed a rather 'scattered pronouncement ${ }^{\prime 303}$ would not constitute a proper status these days. It is quite possible that the World Court would contribute to clarifying the methodology and overall approach of legal reasoning in relation to ascertaining the content of those contracts that appear in a setting of adjudicative public international law. Investment treaty arbitration seemingly released the World Court of that burden.

In what relates to jurisprudence of investment treaty arbitration, one cannot successfully mirror Jean Ho's argument on the role of arbitral awards as a primary source of international law on state responsibility for breaches of investment contracts and suggest that the same awards exhibit the rules of international law on contract interpretation. ${ }^{304}$ Even though one can identify lacunae both for state responsibility for breach of investment contracts and for interpretation of these contracts, that probably would be the only point of alignment. For state responsibility for breach of investment contracts, the lacunae existed in scholarly literature, but not in international law, until Jean Ho capably filled it with her recent monography. Idiosyncratic express reliance on international law on more thorough examination turns out to be a rhetoric that hides ideas of transnational law, ${ }^{305}$ or overrides the application of certain concepts or principles of international law that rather than being directed

303 Clarence Wilfred Jenks, The Prospects of International Adjudication (Stevens \& Sons 1964) 599.

304 Jean Ho, 'Arbitral Awards and the Generation of International Law' in Jean Ho, State Responsibility for Breaches of Investment Contracts (Cambridge University Press 2018) 6189. For the contribution of investment treaty arbitration to general international law, see also Stephan W Schill and Katrine R Tvede, 'Mainstreaming Investment Treaty Jurisprudence: The Contribution of Investment Treaty Tribunals to the Consolidation and Development of General International Law' (2015) 14(1) The Law and Practice of International Courts and Tribunals 94, 94-129.

305 In Lemire v Ukraine (II), ICSID Case No. ARB/ O6/18, Decision on Jurisdiction and Liability dated 14 January 2010, para. 111. With caveats regarding the peculiar and rather contractbased character of the Eurotunnel Arbitration and as discussed, a reliance on the VCLT for interpretation of the concession agreement, it was rather premised on the parties' agreement. 
toward ascertaining the meaning of contractual provisions define their effect under international law. ${ }^{306}$

To conclude, one has to acknowledge occasions when the World Court first understood contracts without relying upon national laws, but that in itself does not necessarily lock that analysis within the exclusive ambit of international law. The World Court considered national laws in relation to contracts and frequently reconfirmed its own findings by relying on national law. While the precise role and function of national law in the reasoning of the World Court may be disputed, what remains rather undisputed is that its jurisprudence does not point to rules in international law on contract interpretation.

\subsubsection{Scholarly Publications}

There is no doctrine of contract interpretation in general international law. There never has been. There was, however, an attempt to find an external axis of stability for state contracts in the general principles of law as a source of international law during the time of the concession disputes prior to the emergence of investment treaty arbitration. Those attempts, while clearly drawing on ideas of the prevalence of the international legal order over national laws, stopped growing in the direction of international law, and changed their trajectory into an affirmation of the transnational legal order. The transition already became noticeable in some scholarly works of the period when authors showed indecisiveness as to the precise nature of general principles representing international law or transnational law. ${ }^{307}$

306 For more detail on the role of international law in deciding on the legal consequences of stabilisation clauses, the limited liability clause, the waiver clause and the forum selection clause under international law, see Chapter 4.

307 In addition to the cited view of Jean-Flavien Lalive, an observation of A A Fatouros can be equally representative. In 1962 A A Fatouros wrote: 'It is clear that there is today a developing practice involving the application of general principles of law to state contracts. There still remain several problems, of course, the most important of which are the determination of the conditions under which such principles are to be applied and the establishment of a method for finding the precise content of the rules involved. It is not yet quite clear under what conditions transnational law is applicable to particular state contracts. There is little doubt as to its applicability when the parties include in the contract itself a provision to the effect that the "proper law of the contract" is transnational law or the general principles of law recognized by civilized nations ...' and further capturing dependency of transnational law upon international law: 'The close relationship between transnational law and public international law makes it probable that the former will depend on the latter for the determination of the precise content of the general principles to be applied.'- A A Fatouros, Government Guarantees to Foreign Investors (Columbia University Press 1962) 293, 294. Somewhat later in 1989, Grant Hanessian clarified the mixed intervening nature of general principle of law as a source of international law and lex mercatoria: 'Both "general 
Unsurprisingly and as discussed, the concession cases from the period preceding investment treaty arbitration continue to retain their legitimacy nowadays regarding the use of the general principles of law as transnational sources. ${ }^{308}$ Together with the IUSCT jurisprudence, they created a fertile empirical ground for the UNIDROIT works on the unification of transnational law. ${ }^{309}$ They also continued to be used as a symbol of justification for a direct applicability of international law to state contracts when it suited the discussion, ${ }^{310}$ without in fact triggering scholarly works willing and capable to elaborate a doctrine of contract interpretation within general international law ${ }^{311}$.

principles of civilized nations" and lex mercatoria are somewhat controversial as there is no consensus on the methodology, normative content, or source of obligation of either of these bodies of law. As applied by the Tribunal, however, these sources of law are blended into a system of obligations that is available for application to the disputes of private parties in international commercial arbitrations.' - see Grant Hanessian, 'General Principles of Law' in the Iran-U.S. Claims Tribunal' (1989) 27 Columbia Journal of Transnational Law 309, 312.

308 A clarification of the idea of transnational law largely coincided with the efforts on unification and harmonisation of uniform sales law that ultimately led to the emergence of international commercial law. On historical precursors to the CISG, see, for instance, Miriam Parmentier, 'Uniform Sales Law', Max Planck Encyclopedia of Public International Law <https://opil.ouplaw.com/view/10.1093/law:epil/978o19923169o/law-978o19923169oe1543> updated August 2015, accessed 25 June 2021.

309 On concession-related disputes in the IUSCT, see André von Walter, 'Arbitration on Oil Concession', Max Planck Encyclopedia of Public International Law <https://opil.oup law.com/view/10.1093/law:epil/978o19923169o/law-978o19923169o-e187> last updated December 2008, accessed 25 June 2021. On the relevance of the IUSCT jurisprudence for the lex mercatoria and the UNIDROIT work, see Charles N Brower and Jason D Brueschke, The Iran-United States Claims Tribunal (Martinus Nijhoff Publishers 1998) 669.

310 See, for instance, Ole Spiermann, 'Applicable Law' in Peter Muchlinski, Federico Ortino and Christoph Schreuer (eds), Oxford Handbook of International Investment Law (Oxford University Press 2008) 94-100.

311 Because of the tight contact with national laws on points of contract regulations, ideas of transnational law seem to be more responsive to contract-related matters and are thus more plausible for theorising the relevance of transnational law for contract interpretation - see, for instance, Miriam Parmentier, 'Uniform Sales Law', Max Planck Encyclopedia of Public International Law <https://opil.ouplaw.com/view/10.1093/law:epil/9780199231 69o/law-978o19923169o-e1543> updated August 2015, accessed 25 June 2021; Stephan W Schill, 'Lex Mercatoria' Max Planck Encyclopedia of Public International Law <https://opil. ouplaw.com/view/10.1093/law:epil/978o19923169o/law-978019923169o-e1534> updated June 2014, accessed 25 June 2021; Michael Joachim Bonell, 'Commercial Contracts, UNIDROIT Principles' Max Planck Encyclopedia of Public International Law <https://opil. ouplaw.com/view/10.1093/law:epil/978019923169o/law-978019923169o-e1888 > updated August 2009, accessed 25 June 2021. See, however, the discussion in Chapter 2 on the relevance of national law for contract interpretation. 
No doctrine has been elaborated since the formation of investment treaty arbitration. If one looks at various theories surrounding internationalisation, one can observe a reincarnation of the role of general principles of law as a source of international law along with the role of the treaty provisions establishing standards of investment protection. Recognising the primary role of international law for treaty-based disputes, scholars nevertheless have acknowledged its limits in relation to contract-related issues. Regarding state contracts, international law enabled their stability, autonomy and textual supremacy, but was not able to address all interpretative moments in contract interpretation. ${ }^{312}$ National laws were more appropriately tuned for that task, whereas the existing limits within international law do not enable it to entirely subsume contract regulation, including contract interpretation. It is accordingly impossible to point to any authoritative scholarly view at the moment that actually suggests that interpretation of state contracts may be entirely disposed of by international law. ${ }^{313}$ An ongoing challenge of the role of general principles as a proper source of public international law ${ }^{314}$ did not help to build a doctrine on their role for contract interpretation either.

No clarification on the role of international law for contract interpretation came from the angle of the emerged doctrine on state responsibility for breach of investment contracts. The chance for clarification was lost when

312 While general principles of law may, via their interpretative approach based on efficiency and integrity, contribute to contract interpretation, there could arise occasions where interpretation is needed for more complex situations. For instance, construction contracts are increasingly seen in investment treaty arbitration as a type of cooperative contract. This type of contractual arrangement may require a meticulous approach to contract interpretation. For instance, in Koza Garanti v. Turkmenistan ICsid Case No. $\mathrm{ARB} / 11 / 2 \mathrm{O}$, it was difficult to interpret the construction agreement by merely reconciling its terms, i.e. ensuring integrity and efficiency. The tribunal had to decide on the meaning of a peculiar reporting system under the contract - so-called SMETA.

313 Again, see the discussion on the limits of the general principles of law for contract interpretation in relation to the proposition made by Charles T Kotuby and Luke A Sobota. Furthermore, Kotuby and Sobota seem to envisage a more transnational role behind the principles. On the divergence of the results that might follow from the application of general principles of law to contracts analysed at the level of remedies, see, for instance, Irmgard Marboe and August Reinisch, 'Contracts between States and Foreign Private Law Persons', Max Planck Encyclopedia of Public International Law <https:/opil.ouplaw. com/view/10.1093/law:epil/978o19923169o/law-978o19923169o-e1391> updated May 2011, accessed 25 June 2021.

314 See, for instance, Jean d'Aspremont, 'What Was Not Meant to Be: General Principles of Law as a Source of International Law' in Riccardo Pisillo Mazzeschi and Pasquale De Sena (eds), Global Justice, Human Rights, and the Modernization of International Law (Springer 2018). 
the International Law Commission excluded issues of state responsibility for breach of state contracts from its codification work on state responsibility. Both reports of the Special Rapporteur on State Responsibility, Fransisco García-Amador, identified, though with a lesser degree of affirmation, ${ }^{315}$ that a contract breach was capable of being attributed to state responsibility. Because of the highly contentious character of the issue, the report of the second Special Rapporteur, Roberto Ago, had already excluded contract breach from the focus of the International Law Commission. ${ }^{316}$ The resulting work of the ILC Articles became known as a general acknowledgement that not every breach of contract by a State is an international wrong as such and that it can be considered as a breach under certain circumstances only, ${ }^{317}$ and was short

315 In his first report, Fransisco García-Amador, addressing acts and omissions which give rise to international responsibility, included those that violate contractual undertakings: 'the non-performance by the State - through the agency of any of its organs - of a contract entered into by the State with an alien, in which case the State is responsible for non-performance.' - F V García-Amador, 'International Responsibility: First Report by F.V. GarcíaAmador, Special Rapporteur' [1956] 2 Yearbook of the International Law Commission 173, UN Doc.A/CN.4/96, p.182. In his second report, Fransisco García-Amador, changed an affirmation to a more conditional statement: ' $[t]$ his is certainly the consideration which decisively influenced the prevailing opinion on the subject, which is that the non-performance of contractual obligations of this type does not per se constitute an international wrong' F V García-Amador, 'International Responsibility. Second Report by F. V. García-Amador, Special Rapporteur' UN Doc.A/CN.4/106, p. 117.

316 Roberto Ago explained the expunction of issues of the non-performance of contracts by states as follows: 'Though responsibility theory had no doubt been based on a body of judicial precedents concerned specifically with violation of the rights of aliens, a distinction must now be made between two subjects: State responsibility in general and the treatment of aliens. The Commission should begin by studying the general principles governing State responsibility, wherever it was incurred, and then perhaps go on to study its application in specific fields, especially that of injury to aliens.' - Roberto Ago, 'First Report on State Responsibility by Mr. Roberto Ago, Special Rapporteur - Review of previous work on codification of the topic of the international responsibility of States' (1969) 2 Yearbook of the International Law Commission $125<$ https://legal.un.org/ilc/documentation/english/a cn4_217.pdf > accessed 26 September 2021.

317 The Commentary to the ILC Draft on State Responsibility provides: 'Of course, the breach by a State of a contract does not as such entail a breach of international law. Something further is required before international law becomes relevant, such as a denial of justice by the courts of the State in proceedings brought by the other contracting party. But the entry into or breach of a contract by a State organ is nonetheless an act of the State for the purposes of article 4, and it might in certain circumstances amount to an internationally wrongful act.' - International Law Commission, 'Draft Articles on Responsibility of States for Internationally Wrongful Acts, with commentaries' (2001) 2(2) Yearbook of the International Law Commission, 41 <http://legal.un.org/ilc/texts/instruments/english/ commentaries/9_6_2001.pdf> accessed 25 June 2021. 
of further elucidations. Jean Ho made an important recent step by attempting to grasp fundamental rules of international law on state responsibility for breaches of investment contracts within customary international law and in international investment law. Drawing primarily on arbitral awards in investment treaty arbitration and not on scholarly works, she managed to formulate the contemporary doctrine of state responsibility for breach of investment contracts, leaving aside, however, the precise interaction between national and international law and the role of the two legal orders for contract interpretation, contract formation, contract validity and contract termination. Contract interpretation went behind the scenes, not least because, most likely, Jean Ho, similarly to Muthucumaraswamy Sornarajah, downplayed the role of contractbased legitimate expectations in the FET. ${ }^{318}$ In any way, no rules of international law capable of dealing with issues of contract interpretation have been identified at the present stage of development of the doctrine on state responsibility for breaches of investment contracts. On the contrary, some works expressly emphasise the role of national law for contract-related concepts that have to be decided first before turning to issues of state responsibility. ${ }^{319}$

Further to the doctrine on state responsibility for breach of investment contracts to elucidate rules within international law for contract interpretation, it may be illustrative that another arena of international law - war and armed conflicts - is equally unable to point to the emergence of international law that would guide the effect of war and armed conflicts on contracts. The effect is still largely in the ambit of national laws. ${ }^{320}$

318 Jean Ho, State Responsibility for Breaches of Investment Contracts (Cambridge University Press 2018) 109-114. For Muthucumaraswamy Sornarajah's critical view on legitimate expectations as the 'most glaring example of expansionary activism', see Muthucumaraswamy Sornarajah, Resistance and Change in the International Law on Foreign Investment (Cambridge University Press 2015) 248.

319 For instance, in the work on the contract-treaty interplay in investment treaty arbitration, James Crawford, recognising the interaction between contracts and treaties, emphasises the role of national law, and alerts against the undue extension of contract-related legitimate expectations beyond the applicable proper law of a contract. Rather unsurprisingly, the paper cannot be construed as being indicative of the availability and suitability of international law rules for ascertaining the content of contractual provisions - James Crawford, 'Treaty and Contract in Investment Treaty Arbitration' (2008) 24 Arbitration International 351,374 .

320 See, Niels Petersen, 'Armed Conflict, Effect on Contracts', Max Planck Encyclopedia of Public International Law <https://opil.ouplaw.com/view/10.1093/law:epil/978019923169o/ law-978o19923169o-e437?rskey=HQzxAa\&result=1\&prd=EPIL $>$ updated September 2015, accessed 25 June 2021. 
The continuous recognition of the relevance of national law, even for interstate commercial transactions, serves as another indication of the lack of a doctrine of contract interpretation in international law. In 1957, F A Mann, who influentially addressed issues of state responsibility for violation of state contracts, ${ }^{321}$ was ready to accept the direct and entire regulation of contracts by (yet to be drafted/enacted) international law, or 'commercial law of nations', only in the case of interstate contracts. ${ }^{322}$ Wilfred Jenks recognised the relevance of public international law for interstate contracts, noting however doubts regarding the capacity of international law to address contractual matters with all necessary detail. ${ }^{323}$ Nowadays, a little over 60 years later, we still have situations in which judges adjudicate disputes of a commercial character in relation to a contract between two sovereigns under national law, the proper law of a contract. ${ }^{324}$ The same national law informs contract interpretation in these disputes. Due to state involvement, public international law arguments arise in these cases, essentially bringing about lengthy discussions on the correcting function of international law, but they do not inform contract interpretation as such. ${ }^{325}$ Overall it appears that public international law does not subsume contract regulation and there are no authoritative scholarly views asserting that international law in fact regulates this issue. If interstate commercial contracting is short of specific rules of international law capable of responding to the task of their interpretation, ${ }^{326}$ what remains to be said for

321 F A Mann, 'The Proper Law of the Contract: A Rejoinder', (1950) 3 The International Law Quarterly 597; F A Mann, 'State Contracts and State Responsibility' (1960) 54 The American Journal of International Law 572.

322 F A Mann, 'Reflections on a Commercial Law of Nations' (1957) 33 British Yearbook of International Law 20.

323 Clarence Wilfred Jenks, The Proper Law of International Organizations (Steven \& Sons 1962) $150-151$.

324 See, for instance, a recent dispute between Ukraine and the Russian Federation on the alleged USD 3 billion loan made to Ukraine through the issuance of Eurobonds in 2013 during the presidency of Victor Yanukovych - Ukraine v. The Law Debenture Trust Corporation P.L.C. P [2018] EWCA Civ 2026 (Court of Appeal).

325 For instance, Ukraine's defence with reliance on public international law was summarised as follows: 'It submits that if as a matter of English law it is otherwise liable to pay the sums due on the Notes, it is entitled to refuse payment as a legitimate counter-measure to the effect of Russian interference on its territorial integrity and economy. The right to take proportionate countermeasures is a recognised principle of public international law on which the English court is competent to rule.' - Ukraine v. The Law Debenture Trust Corporation P.L.C. P [2018] EWCA Civ 2026 (Court of Appeal), para. 20.

326 Michael Waibel suggests, for instance, that 'more than ninety percent of sovereign external bonds issued internationally are governed by New York and English law' - Michael Waibel 'Sovereign Bonds: Internationalization and Partial Privatization' in Mathias Audit and Stephan W Schill (eds), Transnational Law of Public Contracts (Bruylant 
asymmetric contractual relations (state or investment contracts) or contracts not marked by state character at all that also appear in the context of investment treaty arbitration - non-state and non-investment contracts?

In fact, the idea of a special branch of law that would address asymmetric contracting between state and investor was not absolutely unfamiliar during the period preceding investment treaty arbitration where great anticipation of that law heated the discussion and triggered private codification efforts. The idea continues to be observable contemporaneously in times of investment treaty arbitration, though mostly from the opposite angle. During the period preceding investment treaty arbitration, the inadequacy of international law for addressing only 'extreme cases' triggered discussions regarding the necessity of a new set of rules 'which will regulate the performance of state contracts, a body of law which while taking into account the fundamental difference between the parties to such contracts, will not decide all points in the abstract in favour of the one or the other of the parties. Recourse to public international law is possible and desirable, but only as a last resort, when the state actions involved clearly violate its rules. ${ }^{327}$ Regarding the modern period of investment treaty arbitration, overcapacity or over-delivery of international investment law frequently beyond the parties' real undertakings under a contract pushed some authors to declare a de facto emergence of a rather aggressive form of international investment contract law. ${ }^{328}$ Instead of pointing to a coherent set of international law rules, or international law of investment contracts, many publications cannot ignore the numerous disruptions that investment treaty arbitration brings, resulting in conclusions that are inconsistent with the proper law of a contract. ${ }^{329}$ As a rule, these works do not focus distinctly on

2016) 568. Similarly, see Irmgard Marboe and August Reinisch, 'Contracts between States and Foreign Private Law Persons' Max Planck Encyclopedia of Public International Law <https://opil.ouplaw.com/view/10.1093/law:epil/978o19923169o/law-978o19923169oe1391> updated May 2011, accessed 25 June 2021. On the governing law of sovereign bonds, see, for instance, Hayk Kupelyants who challenges the classical perception of the relevance of the law of a sovereign debtor, but still offers an option within national laws the law of the creditor - see Hayk Kupelyants, Sovereign Defaults before Domestic Courts (Oxford University Press 2018) 111-140.

327 A A Fatouros, Government Guarantees to Foreign Investors (Columbia University Press 1962) 283 .

328 Julian Arato, 'The Logic of Contract in the World of Investment Treaties' (2016) 58 William \& Mary Law Review 393, 351, 414.

329 James Crawford, 'Treaty and Contract in Investment Treaty Arbitration' (2008) 24(4) Arbitration International 351; Zachary Douglas, The International Law of Investment Claims (Cambridge University Press 2009) 39-52, 90-94; Julian Arato, 'The Private Law Critique of International Investment Law' (2019) 113(1) American Journal of International 
contract interpretation, but rather on more 'palpable' and much more vulnerable concepts of contract formation, validity and termination. ${ }^{330}$

Occasionally, some commentators envisage the role of general principles of law in the development of the international law of investment contracts, but no strong view is expressed in these works on a set of rules within international law on contract interpretation. My empirical analysis of tribunals' reasoning in relation to contract construction in investment treaty arbitration does not reveal numerous occasions of express reliance on general principles of law as sources of international law. ${ }^{331} \mathrm{~A}$ momentum that general principles of law received for state contracts in the 196os and at the beginning of the 1970s most likely will not be repeated again. And if repeated, resurgent transnational law and not international law would rather inform the content of general principles of law.

It is not only that doctrinal scholarly works do not identify rules in international law for contract interpretation, scholars working in the field of general international law and international investment law in principle rarely address contract interpretation as a distinct object. Despite their scarcity, a few views on contract interpretation observed from the perspective of general international law or international investment law may nevertheless be spotted. They will be addressed below in these final observations even if pointing to the primary or exclusive role of national law.

For works on general international law, one can find discussions on contract interpretation mostly in the form of a perfunctory comparison repeated after Hersch Lauterpacht on similarities between treaty and contract interpretation. These similarities draw on a high level of abstraction that primary and

Law 1; Julian Arato, 'The Logic of Contract in the World of Investment Treaties' (2016) 58 William \& Mary Law Review 351.

330 Only the most extreme situations, when international investment law may be viewed as implying unnegotiated terms to the parties' bargaining - implication of terms - come somewhat closer but not directly to addressing contract interpretation - see Julian Arato, 'The Private Law Critique of International Investment Law' (2019) 113 (1) American Journal of International Law 1, 16-29.

331 Reliance on good faith for contract interpretation is discussed in the section on general principles. A broader principle of pacta sunt servanda was as a rule invoked not as a tool of contract interpretation as such, but rather as an external justification within international law to enforce certain contractual terms. In Daimler Financial Services AG v. Argentine Republic, the tribunal relied on the principle of pacta sunt servanda citing Sapphire v. National Iranian Oil Company, to give full effect to the parties' choice of law. Pacta sunt servanda essentially served as a justification for application of the national law - German law - to contraction of the SPA - see Daimler Financial Services AG v. Argentine Republic, ICSID Case No. ARB/ 05/1, Award of 22 August 2012, para. 146. 
exclusively engage with consent and the parties' intent as common markers. They were not indicative of the interchangeable character of interpretative rules for contract and treaty interpretation. At the same time, existing deeper distinctions between contract interpretation and treaty interpretation have not remained unnoticed. Christopher Greenwood, addressing the relations between international and national laws in a UN audio-visual lecture, spotted important distinctions between rules on treaty and contract interpretation taking English law of contract as an illustration of national law. ${ }^{332}$ His clarification also serves as a negative implication for the availability of the rules of international law for contract interpretation.

For specialised works on international investment law and investment treaty arbitration, contract interpretation as a distinct aspect rarely comes to the forefront. Contract interpretation rather comes as an implicit component for various discussions that surrounds contracts and standards of investment protection. When framed in the vocabulary of IIAs and international law, the issues absorbing contract interpretation most often include the availability and legality of investment, as well as the establishment of legitimate expectations. When framed in the vocabulary of contract law concepts, the issues absorbing contract interpretation more often include contract formation, contract validity and contract termination. Explicit scholarly engagement with the methodology of contract interpretation is still missing.

Exceptional to this observation on the scarcity of works in international investment law, but nonetheless indecisive as to the precise function of international law for contract interpretation, comes a widely cited work on stabilisation clauses by Thomas Wälde and George Ndi. ${ }^{333}$ In the article, the authors acknowledge the relevance of international law for the interpretation of stabilisation clauses. They do not seem to suggest, however, that specific rules relevant for contract interpretation exist in international law, nor does their clarification operate to the exclusion of national law for contract interpretation. Some relevance primarily because of the participation of the state that inevitably brings sovereign-specific features seems to be their primary message:

Treaty law certainly does not have the finely tuned systems of most developed contract law to deal with issues such as commercial impracticability,

332 ICJ Judge Greenwood on the Relationship between International Law and National Law 6 April 2010, <https://legal.un.org/avl/ls/Greenwood_IL.html>accessed 26 September 2021.

333 Thomas Wälde and George Ndi, 'Stabilizing International Investment Commitments: International Law versus Contract Interpretation' (1996) 31 Texas International Law Journal 215 . 
damages, force majeur, or contributory negligence handled by specialized commercial arbitration tribunals. Nevertheless, the more a state contract and the stabilization clause it contains are impregnated by the state character of the agreement, the higher the sovereign content and sovereign intensity of an agreement (with significant implications for typically sovereign-state focused obligations, such as committing a state directly to freeze or not to apply its legislation). Hence, international treaty law may be of some relevance. ${ }^{334}$

The analysis of scholarly works would not be complete without a view on the works of Christoph Schreuer. ${ }^{335}$ Exhibiting and analysing various approaches to applicable law to investment contracts under the ICSID Convention, Christoph Schreuer does not develop a doctrinal view on the distinct role of international law for interpretation of investment contracts, nor does he affirm the existence of the rules of international law for contract interpretation:

International law does not thereby become the law applicable to the contract. The transaction remains governed by the domestic legal system chosen by the parties. However, this choice is checked by the application of a number of mandatory international rules such as the prohibition of denial of justice, the discriminatory taking of property or the arbitrary repudiation of contractual undertakings. ${ }^{336}$

In his other work, written together with Rudolf Dolzer, Christoph Schreuer acknowledges the potential relevance and the applicability of the two legal orders - international law and national law - for investment contracts, but does not suggest any direct relevance of international law for contract interpretation:

Any reference in a choice of law clause to two different legal orders or principles will, in the event of conflict or diversity between them, pose the question of the hierarchy or selection of the legal order for the

334 Ibid. 253 .

335 According to Thomas Schultz and Niccolò Ridi, Christoph Schreuer's commentary to the ICSID Convention has been cited no less than in 161 treaty-based awards - see Thomas Schultz and Niccolò Ridi, 'Arbitration Literature' in Thomas Schultz and Federico Ortino (eds), Oxford Handbook of International Arbitration (Oxford University Press 2020) fn 35 .

336 Christoph Schreuer, The ICSID Convention: A Commentary (2nd edn, Cambridge University Press 2009) 42-115. 
individual issue concerned. A simple reference to domestic law will, in itself, raise the question whether an international tribunal would, in view of its own legal basis and in light of the rules of international law applicable to aliens and foreign companies, invariably consider international rules irrelevant. ${ }^{337}$

Recognising in this final section the absence of a doctrine on contract interpretation in the scholarship on international law, ${ }^{338}$ no suggestion is being made that such a doctrine necessarily has to be developed. National law is more suitable and more finely tuned to dealing exhaustively with issues of contract interpretation. International law maintains a corrective role in relation to contracts. This corrective role may deprive certain contractual provisions or a contract in its entirety of the legal effect under international law, but it does not affect contract interpretation as an ascertaining process as such. What is greatly needed in terms of scholarly work is an elaboration of a doctrinal view,

337 Rudolf Dolzer and Christoph Schreuer, Principles of International Investment Law (2nd edn, Oxford University Press 2012) 81-82.

338 While it may be viewed somewhat mechanically, nevertheless, for the sake of completeness, the most cited sources in the field of international investment treaty arbitration have been closely scrutinised to find out whether they might point to the existence of any rules of international law for contract interpretation and my observations highlighted in this section remained unchanged. As an indication of highly cited works, the work of Thomas Schultz' and Niccolò Ridi' 'Arbitration Literature' is most useful - see Thomas Schultz and Federico Ortino (eds), Oxford Handbook of International Arbitration (Oxford University Press 2020) 2-32. Among the most cited overall works, the works as follows were considered: Susan D Franck, 'The Legitimacy Crisis in Investment Treaty Arbitration: Privatizing Public International Law through Inconsistent Decisions' (2005) 73(4) Fordham Law Review 1521, 1521-1625; Gus Van Harten, Investment Treaty Arbitration and Public Law (Oxford University Press 2008). Among the most cited in 2008-2018 are: Campbell McLachlan and others, International Investment Arbitration: Substantive Principles (2nd edn, Oxford University Press 2017); Christopher F Dugan and others, Investor-State Arbitration (Oxford University Press 2012); Lucy Reed, Jan Paulsson and Nigel Blackaby, Guide to ICSID Arbitration (2nd edn, Wolters Kluwer 2011); Charles N Brower and Stephan W Schill, 'Is Arbitration a Threat or a Boom to the Legitimacy of International Investment Law?' (2009) 9(2) Chicago Journal of International Law 471; Susan D Franck, 'Development and Outcomes of Investment Treaty Arbitration' (2009) 5o(2) Harvard International Law Journal 435; Bruno Simma, 'Foreign Investment Arbitration: A Place for Human Rights?' (2011) 6o International and Comparative Law Quarterly 573; Gus Van Harten, 'Arbitrator Behavior in Asymmetrical Adjudication: An Empirical Study of Investment Treaty Arbitration' (2012) 5o Osgoode Hall Law Journal 211. Also, works included in Classics of International Investment Law do not point to the existence of international rules on contract interpretation - August Reinisch, Classics of International Investment Law (Edward Elgar Publishing 2014). 
or a theory, on interpretative legal reasoning for investment treaty arbitration. ${ }^{339}$ The theory has to engage openly with all the complexities relating to interpretative practices in legal reasoning without limiting its analysis to treaty interpretation. Casting more light on what has only partially been explained so far ${ }^{340}$ and elucidating the precise role of each legal order, as well as the possible coordination between them for interpretative practices, would promote more transparency and predictability in the decision-making and contribute to pragmatic approaches.

\subsection{Conclusion}

The regulatory framework of international law - treaties, conventions and general principles of law - does not offer universal rules that are capable of offering solutions for contract interpretation. The existence of interpretative rules and principles in international law does not permit one to suggest that they can safely substitute national law applicable to contracts in contract interpretation. The VCLT contains provisions on treaty interpretation, but these provisions are rather specific. The Azpetrol case helpfully illustrates that textual preferences in the VCLT, for instance, are not sufficiently strict to comply with the minimalism of contract interpretation under the Law of England and Wales. One may think of other examples which would further distinguish interpretation under interpretative rules of the VCLT and national contract laws. While possessing an inherent interpretative capacity, the principles of international law, such as reasonableness, good faith, or pacta sunt servanda, are not equal to the similar principles in national laws. When applied to contracts, they cannot respond to a broad range of interpretative moments that contracts raise. Good faith as a general principle of international law is not a substitute for the

339 A deep theoretical and empirical insight into a work on the legal reasoning of the Court of Justice of the EU can serve as a good example of the type of scholarly study that investment treaty arbitration needs - see Gunnar Beck, The Legal Reasoning of the Court of the $E U$ (Hart Publishing 2012).

340 Substantial scholarship addresses treaty interpretation in investment treaty arbitration both from normative and empirical perspectives. See, for instance, J Romesh Weeramantry, Treaty Interpretation in Investment Arbitration (Oxford University Press 2012); Christoph Scheuer, 'Diversity and Harmonization of Treaty Interpretation in Investment Arbitration' in Malgosia Fitzmaurice and others (eds), Treaty Interpretation and Vienna Convention on the Law of Treaties: 30 Years on (Martinus Nijhoff 2010); Ole Kristian Fauchald, 'The Legal Reasoning of ICSID Tribunals - An Empirical Analysis' (2008) 19(2) The European Journal of International Law 301. 
concept of good faith in those national contract laws that have it. The harmonised substantive regulation in specific fields of international commercial law that contain interpretative guidance for specific types of contracts, such as the CISG, are of limited relevance for investment treaty disputes.

Observing the limits of exposure of international law to contract interpretation leaves little room for hesitation concerning the view that international law does not regulate contract interpretation. Interpretative rules of international law that occasionally parallel interpretative rules and principles under national laws applicable to contracts are nothing but false friends. Taken normatively, international law does not regulate contract interpretation per se; its rules have rather a limited effect and cannot autonomously and sufficiently address contract interpretation.

That being said, it does not mean that international law is a closed system with no ambitions regarding contract regulation. Having historically observed attempts to subject investment contracts to the direct application of international law, including aspects of its interpretation, it is not excluded that these attempts may be reiterated. Nor are these attempts necessarily bound to fail. At the moment, however, IIAs, while frequently expressly referring to investment contracts, do not as a rule specify anything except what types of contracts can be qualified as investments. Nor are there other reservoirs in international law for universal rules that would apply to contract interpretation.

TABLE 3 Interpretative rules in international law

\begin{tabular}{llll}
\hline Source & $\begin{array}{l}\text { Rules for treaty } \\
\text { interpretation }\end{array}$ & $\begin{array}{l}\text { Rules for statutory } \\
\text { interpretation }\end{array}$ & $\begin{array}{l}\text { Rules for contract } \\
\text { interpretation }\end{array}$ \\
\hline VCLT & + Art.31-33 & - & - \\
CIL & + codified & - & - \\
General & + & - & - \\
Principles & & & + \\
IIAs & + some & + some indication & - \\
& & interpretation in line & \\
& & $\begin{array}{l}\text { with interpretation as } \\
\text { exercised by competent } \\
\text { national authorities }]\end{array}$ & + Art.8 \\
& & &
\end{tabular}


To conclude, international law offers certain remedies in case of state responsibility that arises in relation to the breach of investment contracts, but this remedial capacity does not offer a set of relevant rules that would turn into a functional substitute to national law regulation for contract interpretation. There is no international law on contract interpretation that would be relevant for investment treaty arbitration. 